\title{
Refugee Migration and Electoral
}

\author{
Outcomes $^{\S}$
}

\section{Christian Dustmann, Kristine Vasiljeva and Anna Piil Damm}

\author{
July 2018
}

\begin{abstract}
To estimate the causal effect of refugee migration on voting outcomes in parliamentary and municipal elections in Denmark, our study is the first that addresses the key problem of immigrant sorting by exploiting a policy that assigned refugee immigrants to municipalities on a quasi-random basis. We find that in all but the most urban municipalities, allocation of larger refugee shares between electoral cycles leads to an increase in the vote share for right-leaning parties with an anti-immigration agenda, and we show large differences in voters' responses to refugee allocation according to prepolicy municipal characteristics. However, in the largest and urban municipalities, refugee allocation has - if anything - the opposite effect on vote shares for anti-immigration parties. This coincides with a sharp divide in attitudes to refugees between urban and rural populations, which may be partly explained by distinctive interactions between natives and those with different background in cities and rural areas. Refugee allocation also has a large impact on the anti-immigration parties' choice of where to stand for municipal election, and we provide some evidence that it influences voter turnout.
\end{abstract}

Keywords: immigration, political preferences, re-distribution, welfare, quasi-random allocation JEL codes: H53, I38

\footnotetext{
$\S$ This research was carried out in collaboration with the Rockwool Foundation Research Unit. We are very grateful to Mikkel Mertz for his research assistance and work on this project. We also thank Bente Bondebjerg for sharing her knowledge about the Danish Spatial Dispersal Policy for Refugees. Christian Dustmann acknowledges support by ERC Advanced grant DMEA and the Norface welfare programme.
} 


\section{Introduction}

Over recent years, an unprecedented number of individuals seeking refuge from war and political persecution have migrated to Northern Europe, with $1.26(0.71)$ million refugees seeking asylum in the EU in 2016 (2017). ${ }^{1}$ These events have caused considerable concern among centrist politicians, who fear they may play into the hands of populist parties. There are two key questions in this debate. First, whether and to which extent refugee migrations of the type witnessed over the past years favor populist right-wing parties, and which parties along the political spectrum will lose votes. Second, is there heterogeneity in voting responses across regions, and are immigration-induced changes in voting behavior mediated or exacerbated by particular regional factors such as economic conditions, crime, or past immigration. For instance, are citizens more likely to respond to immigration by voting for radical parties in constituencies with historically high immigration or crime?

One way to answer these questions empirically is to relate variation in voting outcomes to variation in immigrant settlement. This strategy, however, is problematic because immigrants sort into areas in which they want to live and work and such location choices may be related to the same factors that affect voting behavior and/or are directly caused by the political preferences of populations in the receiving regions. In this paper, therefore, we take advantage of a policy that allocated refugees across all 275 Danish municipalities over a 13-year period (1986-1998). ${ }^{2}$ Exploiting the quasi-random variation in the timing of immigrant allocation to municipalities this allows us to estimate the causal

\footnotetext{
${ }^{1}$ Eurostat databaselmigr_asyappctza. UNCHR estimates that in 2015 alone, more than 800,000 migrants crossed from Turkey to Greece, along only one of several migration routes to Northern Europe (see http://rmrpeurope.unhcr.org/2016_RMRP_Europe.pdf). The EU commission estimates 1.5 million refugees for 2016 and 0.5 million for 2017 (see p. 51 of http://ec.europa.eu/economy_finance/publications/eeip/pdf/ip011_en.pdf). See Dustmann et al. (2017) for details of recent refugee movements.

${ }^{2}$ In 1986 , the medium municipality population size was 9,730 with a mean of 18,604 .
} 
impact of refugee allocation on voting outcomes. ${ }^{3}$ The guiding principle of this allocation was to distribute refugees proportionally to pre-existing municipal populations. Importantly, municipalities could not influence the allocation process. Neither could they choose the timing of allocation or the number of refugees allocated to them, nor did they have any influence on the characteristics of the allocated refugees such as their socio-economic backgrounds. Hence, we can provide evidence that refugee allocations were not associated with past election outcomes. Our paper is thus the first that uses a quasi-random allocation design to pinpoint the causal impacts of refugee allocation on voting. Moreover, we can assess how these effects were influenced by pre-policy municipality-specific characteristics, using the variation among a large number of municipalities to which refugees were allocated and election results from three distinct electoral cycles.

We find that refugee allocation has a considerable effect on voting outcomes. Looking at municipalities with a population below the $95^{\text {th }}$ percentile (which, for simplicity, we will refer to as "rural" municipalities throughout the paper), we find that a one percentage point increase in the refugee share of the municipal population between electoral cycles increases the vote share for antiimmigration parties by 1.34 in parliamentary and 2.32 percentage points in municipal elections. These are sizeable responses considering these parties' overall vote shares of 7.60 (5.58) percent in parliamentary (municipal) elections. However, the far right parties are not the only ones to gain. The center-right parties similarly increase their vote share in response to refugee allocation, although to a lesser extent, while parties on the left side of the political spectrum lose. Overall, refugee allocation leads to a clear shift in the vote distribution towards the right of the political spectrum. On the other hand, voter responses to refugee allocation in the municipalities above the $95^{\text {th }}$ size percentile (which,

\footnotetext{
${ }^{3}$ Following the usual convention, we use the term "asylum seeker" for a person seeking asylum and the term "refugee" for a person whose asylum status has been approved.
} 
for simplicity, we will refer to as "urban" municipalities throughout the paper), are markedly different. Here, increased refugee allocation causes - if anything - a decrease in the vote share for antiimmigration parties. This signals a divide in the political responses of urban and rural populations to refugee allocation.

To shed more light on why the anti-immigration parties gained support following local settlement of refugees, we analyze the heterogeneity in responses across municipalities based on observable prepolicy characteristics. In particular, we look at municipality characteristics that capture factors that may shape how individuals form opinions on refugee immigration. These factors include previous exposure to immigrants, crime, unemployment, the share of rich individuals, and the share of residents who actively support the church. Focusing first on the smaller and less urban municipalities, we find that the larger the share of previous immigrants in the municipality, the greater the effect on votes for anti-immigration parties given a specific increase in the refugee share. We further show that the effect of refugee allocation on voting for the extreme right is exacerbated by pre-policy crime in a municipality, and is stronger in areas with larger shares of more affluent individuals. On the other hand, the higher the share of the municipality population that pays church taxes (which we interpret as a measure of altruistic beliefs in the area), the lower the shift in votes to anti-immigration parties in response to refugee allocation. ${ }^{4} \mathrm{We}$ also find evidence that voters respond to the degree to which existing immigrant populations are welfare dependent, meaning that refugee allocation leads to a stronger shift of votes to the anti-immigration parties in municipalities where dependency rates of immigrants are higher.

\footnotetext{
4 "Church tax", which like income tax is deducted from all taxable income, varies across municipalities and in 1985 amounted to between 0.4 and 1.6 percent of income. Paid on a voluntary basis by members of the Danish National (Lutheran) Church, the money is used to fund the church and its activities (renovation of churches and graveyards, education for children and youth, social assistance for the needy, and cultural events). In 2007, 83 percent of the Danish population were church members.
} 
Our findings for large and urban municipalities are quite different. The overall effect of refugee allocation on the vote shares of anti-immigration parties is negative or insignificantly different from zero in both parliamentary and municipal elections. Furthermore, we find that the effect is unaffected by most other pre-policy municipal characteristics including for example the share of previous immigrants. Decomposition analysis shows that differences in pre-policy municipal characteristics cannot explain the difference in vote share responses to refugee allocation between large and urban municipalities and small and more rural municipalities. Altogether, therefore, while we find considerable heterogeneity in municipal populations' voting responses to refugee allocation depending on their pre-policy characteristics, these pre-policy characteristics cannot explain the differences in voting responses between rural and urban municipalities.

We explore the possible reasons for the rural-urban divide in more detail in the last part of the paper. Using data both from several electoral surveys collected at the time the elections took place and from the European Social Survey, we show that attitudes reflecting concern about refugees and immigrants are strongly related to the likelihood to vote for an anti-immigration party. At the same time, these attitudes differ substantially between rural and urban municipalities, which is only partly explained by differences in age, gender and educational composition. We show that those living in urban areas are more likely to have immigrants as friends or work colleagues and that this is associated with more positive attitudes towards refugees - in line with contact theory (Allport, 1954). On the other hand, those in rural municipalities are more exposed to refugees in their immediate neighborhood. Such exposure, most likely perceived as involuntary, may enhance perceived threat from these communities and steer hostility, in line with group threat theory (see e.g. Campbell 1965; Sidanius and Pratto, 1999). Based on administrative data that allows us to measure the precise settlement of refugees within municipalities, we provide evidence that increased exposure is indeed associated with more negative 
attitudes towards refugees. Thus, those in rural and urban areas both encounter individuals with different background, but in different ways, which may shape their attitudes differently, and partly explain the urban-rural divide in attitudes and vote share responses.

Our paper is not the first to explore the effect of immigrant population density on attitudes or voting behavior. For example, Dustmann and Preston (2001) examine the effect of resident immigrant share on xenophobic attitudes, hypothesizing that it could either intensify negative attitudes as predicted by context theory (see e.g., Levine and Campbell, 1972) or alleviate them as suggested by the contact hypothesis. As regards voting behavior, although a number of earlier studies ${ }^{5}$ investigate the more direct effect of immigrant share on voting for populist and anti-immigration parties, most fail to address the sorting problem. More recent papers, on the other hand, use IV type strategies to investigate the link between immigration and voting for radical parties. For example, Barone et al. (2016), Halla, Wagner and Zweimüller (2017), Mendez and Cutilla (2014) and Otto and Steinhardt (2014) examine voting outcomes in Italy, Austria, Spain and Hamburg (Germany), respectively. They use an IV estimator similar to that employed by Altonji and Card (1991) to predict current immigrant stocks based on historical settlement. ${ }^{6}$ Harmon (2017) and Steinmayr (2016) investigate voting behavior among Danes and Austrians respectively, based on an IV strategy that uses availability of living space as a predictor of immigrant settlement. ${ }^{7}$ Our paper is also somewhat related to recent work by Dahlberg, Edmark and Lundqvist (2012) on the impact of refugee placement in Sweden on popular

\footnotetext{
${ }^{5}$ See, for example, Lubbers, Gijsberts and Scheepers (2002), Campbell, Citrin and Wong (2006), Gerdes and Wadensjö (2010), and Jensen and Thomsen (2013). For additional factors that contribute to the growth of anti-immigration parties unrelated to their stance on immigration, see Andersen and Bjørklund (1990), Betz and Johnson (2006), Norris (2005), Simonsen (2007), Rydgren (2010), and Givens (2012).

${ }^{6}$ See Ruist, Stuhler and Jaeger (2017) for a critical review of this methodology.

${ }^{7}$ By focusing on how immigration affects voting on immigration issues in Switzerland and instrumenting the share of immigrants in a community with the share of foreigners in the local labour market, Brunner and Kuhn (2014) further show that anti-immigration votes are larger in communities with more culturally different immigrants.
} 
support for redistribution, although these authors focus not on political outcomes but on whether Swedish residents are willing to preserve the existing social benefit level.

We contribute to this literature in several ways. While most of the before mentioned literature investigates economic migrants, our focus is on refugees - the group that has so dramatically affected the political debate in Europe and beyond. One major innovative advantage of our study is that instead of the IV approach used in previous work, we employ a design that exploits the quasi-random variation in refugee allocation to different municipalities over a sustained period that encompasses three electoral cycles. We also focus on changes in voting outcomes between two electoral cycles as a response to changes in refugee allocation, which allows eliminating municipal-constant factors and tighten our design even further. The large variation due to random assignment enables further exploration of channels that mediate the possible effect(s) of immigration on voting behavior by interacting changes in refugee shares with municipal characteristics measured in the year preceding policy implementation. Rather than focusing on right-wing populist parties like most papers, we examine the entire spectrum of electoral outcomes. ${ }^{8}$ By showing that not only anti-immigration but also center-right parties gain from immigration-induced changes in voter behavior while center-left parties lose, we contribute important evidence to the debate on political radicalization through immigration and refugee allocation. We also contribute new evidence on two other aspects: voter turnout in response to immigration, and how past refugee allocations affect the decisions of anti-immigration parties on whether to run in municipal elections. Our results indicate that refugee allocation increases voter turnout in municipality elections. We further find that anti-immigration parties respond strongly to refugee allocations when

\footnotetext{
${ }^{8}$ Gerdes and Wadensjö (2010) investigate the association of immigration and vote shares for all parties separately, while Harmon (2017) considers anti-immigration and left wing parties, Otto and Steinhardt (2014) consider votes for the green party, Mendez and Cutilla (2014) focus on the ratio between vote shares for the two major parties, and Stainmayr (2017) considers anti-immigration votes as well as the aggregate vote share for all other parties.
} 
deciding in which municipality to stand. Further, we illustrate stark heterogeneity in vote share responses to refugee allocation according to pre-policy municipal characteristics, a result that puts into question random assignment policies. Finally, we show a rift in vote share responses between urban and rural municipalities. To explain this divide, we show that there are differences between rural and urban populations in attitudes towards refugees that are strongly associated with the likelihood to vote for anti-immigrant parties. We illustrate that such attitudinal differences are related, with opposite sign, to more voluntary contact of urban populations with immigrants, and more involuntary exposure to refugees by rural populations in their immediate neighborhood.

We develop the remaining discussion as follows: Section 2 describes Denmark's voting system, its political parties, and the data used in the analysis; Section 3 outlines the conceptual framework and empirical methodology; Section 4 reports our findings, Section 5 investigates explanations for the rural-urban divide in vote share responses, and Section 6 concludes the paper.

\section{Background}

\subsection{Political Parties in Denmark}

Denmark is a representative democracy with parliamentary elections typically held once every four years and a multi-party political system comprising two large mainstream groups: the center-left wing and the center-right wing. Whereas the former is typically led by Social Democrats and the Social Liberal Party, the latter is led by Denmark's Liberal Party and the Conservative People's Party. In parliamentary elections, the electoral threshold (i.e., the total votes a party must receive to enter parliament) is 2 percent (Folketinget 2009). ${ }^{9}$ Two other parties are positioned to the right of the center-

\footnotetext{
${ }^{9}$ Furthermore, a party which is not represented in parliament must collect $1 / 175$ of the total number of valid votes cast at the previous election as signatures in order to stand for the next parliament election (http://valg.sim.dk/partier-ogkandidater.aspx). Usually, these are around 20,000 signatures.
} 
right: the Progress Party (PP, Fremskridtspartiet) and the Danish People's Party (DPP). The first, founded in 1972 on a libertarian platform, advocates the abolishment of income tax and large cuts in government spending. In the mid-1980s, the PP, capitalizing on growing anti-immigration sentiments that coincided with a stark increase in the number of asylum seekers, developed an anti-immigration agenda and established itself as the first Danish anti-immigration party (Rasmussen 2004). In 1995, the party split, leading to the foundation of the DPP (Rydgren 2010), which like the PP positioned itself as an anti-immigration party, but one closer to the political center. In addition to advocating lower income taxes without progressive redistributive elements in the tax system and the reform of the public sector, the DPP supported publicly provided health care, care for the elderly, publicly financed education, and an increase in the tax-free earnings threshold (Dansk Folkeparti 1997; Simonsen 2007). It also maintained a strong economic program and used less extremist rhetoric to appeal to more central voters (Rydgren 2004). The DPP gained an increasing share of votes partly at the expense of the PP, and also earned support among working-class voters. In 2001, the PP's share of votes fell below the electoral threshold of 2 percent and it has been unable to return to parliament since, whereas by 2015 the DPP had become the second largest party in the Danish parliament with stronger support in rural than in urban areas. ${ }^{10}$

Like parliamentary elections, municipal elections are held every four years, but the dates do not usually overlap with national elections. Moreover, whereas the right to vote in parliamentary elections is reserved for Danish citizens, European citizens and immigrants who have resided in Denmark for at least three years are eligible to vote in municipal elections. The same parties that are represented in parliamentary elections usually also run in municipal elections, although not necessarily in every

${ }^{10}$ See https://www.information.dk/indland/2015/06/valget-delte-danmark. 
municipality. In municipal elections, also local parties stand that focus on issues of particular concern for a certain municipality. Although there is no official electoral threshold for municipal elections, the party must receive enough votes to put at least one mandate on the municipal board. ${ }^{11}$

Our analysis focuses on the 1989-1998 period, which includes three parliamentary and three municipal elections and covers most of the 1986-1998 Danish Spatial Dispersal Policy. Figure 1 gives the dates of these elections and shows which parties were in government. From 1989 to 1994, only the PP was running as an anti-immigration party but in the last year covered by the data (1997/1998) the DPP also participated in both parliamentary and municipal elections for the first time. ${ }^{12}$ The growing concern during this period about refugees and immigrants was reflected by an increased public debate about asylum issues. Figure A1 therefore graphs the number of articles in which the term "refugee(s)" appeared in the Danish national print media between 1991 and 1998. As the figure shows, usage peaked in the municipal election years of 1993 and 1997 whereas no such peaks are evident in the parliamentary election years of 1994 and 1998.

Table 1 then lists the vote shares of all parties in the parliamentary and municipal elections taking place during our 1986-1998 observation period, which are also broken down by election year in Table A1. Row 1 of Table 1 reports the sums of the vote shares for the two anti-immigration parties, the DPP and PP, which average 7.6 percent and 5.6 percent in parliamentary and municipal elections, respectively. Over the study period, the center-left parties received an average of 51 (48) percent of the overall votes at parliamentary (municipal) elections compared to the 34 (36) percent received by the

${ }^{11}$ See http://denstoredanske.dk/Samfund,_jura_og_politik/Samfund/Valgteorier_og_valgmetoder/kommunalvalg.

12 The voting statistics for all the political parties in parliamentary elections are from the Danish Ministry of Social Affairs and the Interior (http://sim.dk/arbejdsomraader/kommuner-og-regioners-styrelse/publikationer.aspx), while those for municipal elections are from Statistics Denmark's municipal voting database (http://www.statbank.dk/statbank5a/default.asp?w=1920). 
two major center-right parties. Row 5 summarizes the votes received by a number of smaller parties that either support right or left or stay centrist.

\subsection{Refugee Migration and the Danish Spatial Dispersal Policy}

In 1956, following its 1952 ratification of the 1951 United Nations Convention on the Status of Refugees Denmark established the Danish Refugee Council (DRC), tasked with supporting asylum seekers in their application for refugee status and residence permits. In response to a large inflow of refugees in the early 1980s, the Danish Government implemented a policy in 1986 through the DRC whose guiding principle was equal distribution of refugees across counties and municipalities according to pre-existing populations. This allocation was implemented as a two-stage process. In the first stage, individuals who received asylum (i.e. obtained "refugee status" and became "refugees") were allocated to one of the 15 counties of Denmark proportional to the counties' populations. ${ }^{13}$ In the second stage, refugees were allocated to municipalities within counties, again relative to the population size in these municipalities. The equal allocation across municipalities within a county was aimed to be achieved over a 3-5-years period. ${ }^{14}$ For that purpose, the DRC established regional offices in the counties, which changed location regularly to ensure equal distribution of refugees across municipalities within counties over a longer term. According to the Ministry of Interior, "The distribution [across municipalities] is sought to be obtained over a period of 3-5 years moving integration offices regularly from some municipalities to others within the county" (Ministry of the

\footnotetext{
13 "Since 1985 the Danish Refugee Council's geographical distribution of refugees has aimed at distributing refugees relatively equally relative to the population in each county [...]". (DRC, 1988, p. 8).

${ }^{14}$ Letter from the Minister of Social Affairs to municipalities and counties (copies to the DRC received on the 26th of March 1987): "If the integration policy shall succeed, it is essential that all municipalities participate in the task. [...] A completely equal distribution each month or year would not be appropriate to practice. [...] Over a longer period the possibility for a more equal distribution will be greater. [...] The distribution will aim at municipalities receiving an equal number of refugees relative to the population size. [...]"
} 
Interior, 1993, p. 44). ${ }^{15}$ This creates variation across municipalities in the short term that we utilize for identification. We illustrate this in Appendix Figure A2, which shows that municipalities receiving the largest refugee share between the first two electoral cycles tend to receive fewer refugees between the second and third electoral cycle, and v.v.

Importantly, municipalities had no influence on the allocation process. This is a key prerequisite for our identification strategy as it excludes that past election results can influence future refugee allocations. Municipalities could neither choose the timing of allocation or the number of refugees allocated to them, nor did they have any influence on the socio-economic background or other characteristics of refugees. This type of information was also not available to the refugee council. The DRC only informed municipal authorities that they had assisted a refugee to find housing in the area after that individual had settled in the municipality. Since over time the composition of refugees arriving in Denmark changed, the within-county rotation scheme will have led to some clustering of individuals from the same origin in some municipalities. ${ }^{16}$ Also, while the overriding principle was equal allocation, the DRC took account of "the need of refugees for social interaction with their fellow countrymen" which suggests that groups of individuals from the same origin may have been allocated together. We show below that neither skill composition nor origin composition of allocated refugees is associated with past election results.

15 "To obtain a reasonable distribution of the burden between municipalities, the committee recommends a kind of rotation scheme where integration offices move from one town to another." ("DRC, 1988, p. 5)". "During 1985 and 1986 one center in each county [...] was established and sub-centers of these centers were established in 35-47 towns spread across the country. [...] Sub-centers were closed and opened in other towns within the county when [...] the goal of a balanced average number of refugees relative to the population size had been reached in the given area ("Note to the Public Accountants in relation to inspection of the refugee administration on August 25.-26. 1988, p. 1").

${ }^{16}$ For instance, from 1989-1993 68\% of all allocated refugees were from the Middle-East, roughly 11\% were from Africa and 22\% from Asia. Over the period 1993-1997 the share of middle-eastern refugees fell to 47\%, while the share of African refugees increased to $40 \%$, and the share of Asian refugees fell to $13 \%$. 
During the assignment process, the DRC did not take refugees' location preferences into account. While reassignment requests were considered, this happened only after the individual had moved into the assigned municipality. Our identification strategy therefore relies on the original share of refugees assigned to each municipality.

The equal allocation policy was subject to municipalities having the necessary resources to accommodate refugees, in particular rental housing units. We account for this in our estimation strategy. Further, the policy took into account the number of existing immigrants before the start of the policy in 1985. This only has consequences for the two municipalities Copenhagen and Frederiksberg that constitute the capital, and that had large non-European immigrant populations before the start of the allocation policy. ${ }^{17}$

The policy was in place from 1986 until 1998. In 1998, a new spatial dispersal policy on refugees was voted by the Danish Government as part of the Danish Integration Act. It was implemented on the $1^{\text {st }}$ of January 1999 and is still in place today. This new policy allows municipalities in each county to negotiate the municipal quota with the Danish Immigration Service. Further, municipalities can affect the number of assigned refugees, and the Danish Immigration Service takes into account individual wishes about location of assignment. As the features of the after-1998 policy invalidate our design, we focus our analysis on the period up to 1998 .

\subsection{Population Size and Refugee Assignment}

Over the 1986-1998 period, 76,673 individuals were granted refugee status and allocated across municipalities (Statistics Denmark 1992, 1997, 2000) in accordance with the allocation policy. ${ }^{18} \mathrm{We}$

\footnotetext{
${ }^{17}$ In robustness checks, we illustrate that exclusion of these municipalities does not affect our estimates much.

18 The average total population of Denmark over the 1986-1998 period was 5.2 million.
} 
display the allocated refugees as a share of the Danish population in 1986 in Figure A3. As the figure shows, this share approaches 0.8 percent in $1998 .^{19}$

Two years after the introduction of this allocation policy, refugees had been assigned to 243 out of 275 Danish municipalities (Danish Refugee Council 1987, pp. 30-31) and their geographical distribution closely resembled that of the overall population. Figure 2a, which plots the 1986 population size against the number of refugees allocated in 1986-1998, reveals that counties with larger populations received larger numbers of refugees. Figure $2 b$ then plots the same numbers for municipalities, revealing reciprocity between municipality size and refugee allocation on this level. The figure also illustrates municipal size heterogeneity, with the urban centers of Copenhagen, Aarhus, Odense, Aalborg and Frederiksberg being the largest. Finally, Figure 2c illustrates the relation between the 1986 population size and refugee allocation over the time of the policy for these 95 percent smaller municipalities. The slope of the regression line is 0.008 , which corresponds to 0.8 percent overall share of refugees allocated under the policy between 1986 and 1998 (see Figure A3). Although the strong relation between allocated refugees and pre-policy population size is again apparent, there is also much variation in allocation numbers between similarly sized municipalities. This variation is a result of the fact that this particular dispersal policy was only in place for a limited period of time and the regional office rotation scheme in conjunction with a large variation in yearly inflows. Together, this left some municipalities with a lower proportion of refugees at the end of the policy period.

It is not this variation in refugee allocation between municipalities, however, that we use for identification in our analysis. Rather, we employ the within-municipality variation between two

\footnotetext{
${ }^{19}$ We exclude refugees from the former Yugoslavian countries who arrived in Denmark during the Balkan wars. These refugees were subject to a special refugee dispersal policy implemented in 1993, which did not fulfil the requirements of our design. We show in Table A2 that the allocation of these refugees is orthogonal to the allocation of refugees dispersed under the dispersal policy.
} 
electoral cycles as illustrated in Table A3. As the table shows, although the mean share of refugees allocated from 1986 up to each parliamentary election year is about 0.38 percent, there is substantial variation not only between but also within municipalities. Substantial within-municipality variation is also observable in the changes in refugee shares between the two electoral periods (row 2).

\subsection{Data}

We derive our data from two primary sources: Statistics Denmark's micro-level registers and its publicly available databases of municipal-level variables. To identify refugees over the 1986-1998 period, we use micro-level data from the Danish population register. Specifically, we first identify the municipality of initial placement and then calculate the share of refugees allocated to each separate municipality from 1986 until the year preceding each election year. To avoid possible correlation between the refugees' re-allocation decisions and factors that influence voting behavior, we use the cumulative share of allocated refugees rather than the number of refugees residing in the municipality. ${ }^{20}$ Likewise, when computing the share of allocated refugees in municipal populations, we use the local population size at the beginning of 1986 rather than population sizes for each respective year. ${ }^{21}$

We then use information from population, education, income, labor and socio-economic registers to construct variables that characterize the municipality in 1985 , the year before refugee dispersal began. These municipality characteristics include the share of immigrants, mean log gross earnings per capita, the share of rich, ${ }^{22}$ the share of immigrants, crime rates, the share of those who pay church taxes,

\footnotetext{
${ }^{20}$ Since family reunified refugees where not subject to the dispersal policy unless they immigrated shortly after their spouse, we exclude spouses and children of refugees who immigrated to Denmark more than 12 months later.

${ }^{21}$ We show below that there is no evidence of natives leaving municipalities as a response to refugee allocations.

${ }^{22}$ We define a rich individual as an adult whose disposable income as a household member is above 50 percent of the Danish median.
} 
the local unemployment rate, the share of individuals with tertiary education, and the welfare dependency of immigrants. To create these variables, we first compile demographic information such as age, personal and family income, employment data and education level for each individual residing in a municipality in 1985 . We then aggregate these data to municipality level and construct the shares corresponding to each municipality's population. Lastly, we standardize these variables to have a mean of zero and a standard deviation of one (see Table A4 for detailed variable definitions and data sources).

\subsection{Descriptive Statistics}

Our analysis focuses on the overall pool of refugees received over the 1986-1998 random allocation period who initially received a permanent residence permit. The origin countries of these refugees are Lebanon, Iran, Iraq, Somalia, Sri Lanka, Vietnam, Afghanistan, Ethiopia, along with refugees without a citizenship -similar to those of the recent refugee movements to Europe. We profile the refugees and the municipalities to which they were allocated in Table A5 and Table 2. About 61 percent of the refugees were male, and one in two arrived with family. They also tended to be young, 25 on average, but also rather poorly educated with only 25 percent having at least one professional qualification compared to 45 percent of native Danes in the same period. Perhaps not surprisingly, therefore, they experienced remarkably high initial non-employment rates with 96 percent remaining unemployed 2

years after approval of their asylum application, ${ }^{23}$ although this number decreased to about 68 percent after 10 years.

\footnotetext{
${ }^{23}$ Non-employment is defined as being unemployed or not in the labour force at ages 18 to 65 . In Denmark, both groups are entitled to some type of benefit.
} 


\section{Theoretical Considerations, Empirical Methodology and Interpretation}

\subsection{Conceptual Considerations}

According to contact theory (Allport, 1954), interaction between ethnic groups can lead to more understanding and reduction of prejudice under four conditions: equal group status, common goals, intergroup cooperation and authority support. Pettigrew (1998) stresses that - unless these circumstances are met - intergroup interaction may negatively affect prejudice, a hypothesis that finds support in empirical research by e.g. Brooks (1975) and Bradburn et al. (1971).

Other hypotheses in the social sciences emphasize negative responses to inflows of identifiable newcomers. Economists, for example, usually point out that individual attitudes towards and opinions on immigrants are driven by concerns of economic self-interest, affecting labor market opportunities, neighborhood and quality of life (see e.g. Downs, 1957; Scheve and Slaughter, 2001; Dustmann and Preston, 2007; Facchini and Mayda, 2009). Attitudes towards minority groups may also be determined by a wider sense of collective threat from groups competing against the majority's economic, social, and cultural dominance (see the seminal work by Key 1949; see also Blumer 1958; Blalock 1967; Bobo 1983). Campbell (1965) categorizes a variety of theories that link inter-group relations to inter-group competition for real resources under the rubric "realistic group conflict theories" (RGCT). Modern versions of this framework posit that competition between groups engenders the belief in a "group threat", which in turn leads to prejudice and negative stereotyping by members of one group against the other while simultaneously bolstering within-group cohesion (Sidanius and Pratto, 1999). In line with this perspective, Quillian (1995) and Lahav (2004) argue that the larger the fraction of immigrants already in the country, the larger the threat natives perceive from additional immigrants. Similarly, Taylor (1998) suggests that increased exposure to the group posing the threat increases the threat's 
salience, implying that natives living in high-immigrant areas will be more opposed to refugee allocation. A further RGCT prediction is that "resource stress" (Esses et al. 2001) or "economic vulnerability" (Citrin et al. 1997) will enhance perceptions of the threat posed by competing groups, an assumption that is highly relevant when areas experiencing economic difficulty are exposed to refugee allocation.

Thus, these theories suggest that the presence or allocation of individuals of different backgrounds in one's immediate neighborhood may trigger prejudice (and ultimately affect voting behavior), by generating a sense of collective threat or individual disadvantage, unless such interaction is taking place under particular conditions, as suggested by the contact hypothesis. Making use of the heterogeneity across municipalities in pre-policy characteristics, we investigate below how the effect of inter-cycle changes in refugee allocation on voting outcomes for anti-immigrant parties is exacerbated or mitigated by the receiving municipality's characteristics. Using attitudinal data from various surveys and detailed information on the settlement pattern of refugees within municipalities, we will further explore the channels that may lead to heterogeneous vote share responses to refugee allocation across municipalities.

\subsection{Estimation and Identification}

To identify the effect of refugee allocation on voting outcomes, we regress the change in the vote shares of political party $p$ in municipality $i$ between election year $t-1$ and $t, \Delta V S_{i t}^{p}$, on the change in the share of refugees relative to the municipality's total population at the beginning of 1986 allocated to that municipality between the same two election years, $\Delta R S_{i t}$ :

$$
\Delta V S_{i t}^{p}=\alpha_{1}^{p} \Delta R S_{i t}+\Delta \tau_{t}^{p}+\Delta \epsilon_{i t}^{p}
$$


where $\Delta \tau_{t}$ are time fixed effects. This difference equation eliminates any municipality specific characteristics that may affect voting outcomes and refugee allocation alike such as the stock of available housing at the beginning of the assignment policy. ${ }^{24}$ Our parameter of interest is $\alpha_{1}^{p}$, the effect of the share of allocated refugees on the voting share for party group $p$. As $\Delta R S_{i t}$ measures the change in the share of allocated refugees this parameter has an intention-to-treat (ITT) interpretation. Because $\sum_{p=1}^{4} \Delta V S_{i t}^{p}=0$, the $\alpha_{1}^{p}$ sum to zero and can therefore be interpreted as the percentage point change in vote shares from election year $t-1$ to election year $t$ for party $p$ induced by a one percentage point change in refugee allocation over the same period.

Consistency of the estimate of $\alpha_{1}^{p}$ requires that $R S_{i t}$ is strictly exogenous in equation (1), i.e. $E\left(\Delta \epsilon_{i t}^{p} \mid R S_{i s}\right)=0 \forall s$, which excludes that past election outcomes affect future refugee allocations. This is ensured by the assignment policy in place over the study period, which precludes any possibility that a policy shock that increases the anti-immigration parties' vote share in the past electoral cycle will lead to a lower share of allocated refugees in period $t$ (see Section 2.2). We will nevertheless test this assumption below.

We allow for different responses of smaller, rural municipalities and larger, urban municipalities, by estimating

$$
\Delta V S_{i t}^{p}=b_{1}^{p} \Delta R S_{i t}+b_{2}^{p} \Delta R S_{i t} D_{i x}+\Delta \tau_{t}^{p}+\Delta \tau_{t}^{p} D_{i x}+\Delta u_{i t}
$$

where the dummy variable $D_{i x}$ indicates whether municipality $i$ 's size is above the $x^{\text {th }}$ percentile of the municipality size distribution. ${ }^{25}$

\footnotetext{
${ }^{24}$ The underlying level equation is $V S_{i t}^{p}=\alpha_{0}^{p}+\alpha_{1}^{p} R S_{i t}+\gamma_{i}+\tau_{t}^{p}+\epsilon_{i t}^{p}$, where the $\gamma_{i}$ denote municipality fixed effects. ${ }^{25}$ In most specifications, we will distinguish between the 5\% largest and urban and the 95\% smallest and more rural municipalities.
} 
We are also interested in whether municipal characteristics in the pre-policy year of $1985, Z_{i 0}$, mitigate or exacerbate the effect of refugee allocations on vote shares for anti-immigrant parties. We therefore extend equation (1) by adding interaction terms between these municipality characteristics and the share of allocated refugees to estimate ${ }^{26}$

$$
\Delta V S_{i t}^{p}=\beta_{1}^{p} \Delta R S_{i t}+\beta_{2}^{p} \Delta R S_{i t} \times Z_{i 0}+\Delta \tau_{t}^{p}+\Delta e_{i t}^{p} .
$$

The variables $Z_{i 0}$ are normalized to have a mean of 0 and a standard deviation of 1 based on the 1985 distribution across 275 municipalities. Again, because the $\beta_{1}^{p}$ sum up to zero over all parties $p$, the estimated parameters for $\Delta R S_{i t} \times Z_{i 0}$ also sum to zero over all parties. We estimate the two specifications separately for parliamentary and municipal elections using interactions.

\section{Empirical Analysis}

\subsection{Testing the Identifying Assumptions}

To verify that past election results do not affect present refugee allocations, an intuitive test is whether past changes in the municipal council's seat (or vote) composition (i.e. between election years $t-2$ and year $t-1), \Delta Y S_{i t-1}^{p}$, affect current changes in the share of allocated refugees to that municipality (i.e. between $t-1$ and $t$ ), $\Delta R S_{i t}$. In addition to vote shares, we compute seat shares after each municipal election for all election years. Seat and vote shares are highly correlated in municipal elections - with correlation coefficients being 0.98 for center-left and small center parties, 0.97 for center-right parties and 0.88 percent for anti-immigration parties (based on 1989/1993 data). We then estimate the following regression model:

$$
\Delta R S_{i t}=d_{1} \Delta Y S_{i t-1}^{p}+\tau_{t}^{p}+e_{i t}
$$

\footnotetext{
${ }^{26}$ It should be noted that the levels of the variables in $Z_{i 0}$ are eliminated through differencing.
} 
Results are reported in Table $3 .^{27}$ The estimates in Panels A and B suggest that there is no systematic impact of changes in vote or seat shares over the past election cycle on the allocated share of refugees over the current election cycle. Changes in the lagged seat (vote) share of anti-immigration parties is - if anything - positively related to the allocation of refugees.

We also estimate models where we regress the allocation of refugees on changes in the vote shares for anti-immigrant parties, lagged by one, two and three periods (first two columns of Panel C). As the design of the allocation policy to rotate allocation across municipalities over time may create a mechanical correlation between current and past refugee allocations, we also estimate these specifications conditioning on past refugee allocations (last two columns of Panel C). Estimates show no systematic relation between lagged changes in vote shares and current refugee allocations, neither conditional nor unconditional on past refugee allocations. ${ }^{28}$

A more general test for the validity of our design is the strict exogeneity test suggested by Wooldridge (2010), which corresponds in our case to testing whether $\gamma$ is significant in the regression:

$$
\Delta V S_{i t}^{p}=b_{1}^{p} \Delta R S_{i t}+\gamma^{p} R S_{i t}+\Delta \tau_{t}^{p}+\Delta e_{i t}^{p}
$$

A test for strict exogeneity is then a test of the null hypothesis $H_{0}: \gamma=0$ against the alternative $H_{1}: \gamma \neq 0$. We have implemented this test for the main specifications we estimate below and report results in Table A7. In none of the cases, the null hypothesis can be rejected.

\subsection{Additional Balancing Tests and Native Out-migration}

\footnotetext{
${ }^{27} \mathrm{We}$ focus on municipal elections, as the national parliament is unlikely to implement a policy that addresses the concerns of a particular municipality. Results for parliamentary elections are in line with those reported here. For instance, for antiimmigrant parties, we estimate $d_{1}$ to be 0.0069 , with standard error 0.0102 .

${ }^{28}$ We have also regressed the allocation of refugees over the current election cycle on lagged change in turnout. Again, there is no systematic relation between these variables, see Table A6.
} 
The design of the allocation policy suggests that educational composition and composition according to origin groups of allocated refugees is uncorrelated with past election outcomes. To investigate this, we report in Table A8 estimates where we regress the share of refugees in different educational categories allocated to a municipality between two electoral cycles on the lagged share of votes for anti-immigration parties (columns 1-6). All these estimates are small and insignificant, as is the relation between the municipality having received no refugees over the past electoral cycle and the lagged share of votes for anti-immigration parties (column 7).

We then run similar regressions, where the dependent variable is now the share of allocated refugees from three different origin groups which are Middle-Eastern (Irak, Iran, Lebanon, Afghanistan), African (Somalia, Ethiopia), and Asian (Vietnam, Sri Lanka) (see Table A9 in the Appendix). Again, the estimates suggest no systematic relation between the lagged change in the share of votes or seats for anti-immigration parties and the current allocation share of refugees from any of these three groups. This confirms our conjecture based on the policy design that municipalities were not able to influence the socio-economic composition or origin of refugees allocated to them.

As we point out above, estimation of equation (1) is robust to pre-policy municipal characteristics $Z_{i 0}$ affecting refugee allocation. However, interpretation of equation (2) assumes that $E\left(\Delta e_{i t}^{p} \mid \Delta R S_{i t} \times Z_{i 0}\right)=0$. This assumption may be violated if differencing does not eliminate all components in the error term that are correlated with pre-policy municipal characteristics. To check whether refugee allocation is balanced with respect to pre-policy municipal characteristics, we regress the municipal allocation of refugees over the sample period on the variables in $Z_{i 0}$. As we distinguish below between urban and rural municipalities (i.e. between the 5\% largest and 95\% smallest municipalities), we do the same here. Further, as housing considerations may have affected the 
allocation policy of the council, we present these balancing tests conditional and unconditional on the available rental housing stock in the base period.

The estimates in columns 1 and 2 of Table A10 show that refugee allocations are not correlated with municipality characteristics in the base period for the $95 \%$ more rural municipalities, both conditional and unconditional on the stock of available housing. For the 5\% urban municipalities, some of the pre-policy municipal characteristics turn out significant such as the share of immigrants and log gross income. This may be driven by the capital municipalities Copenhagen and Frederiksberg that received many non-Western immigrants already before the policy was implemented and that were therefore treated slightly differently during the allocation phase (see our discussion in Section 2.2). When we exclude these two municipalities, none of the pre-policy characteristics is significant, conditional on the initial housing stock (see Column 6). Below, we therefore report robustness checks where Copenhagen and Frederiksberg are excluded.

One additional concern may be that natives leave areas as a response to the allocation of refugees. To investigate this possibility, we compute the mobility of natives across municipalities based on data from the Danish Population registers and construct a variable of the net share of native adults who leave a municipality between election cycles. We then regress this variable on refugee allocation following Card (2001). The estimates show no significant relation between refugee allocation and native net outflows. ${ }^{29}$

\subsection{Main Results}

Table 4a summarizes the equation (1) and (1-a) (for $x=95 \%)$ results for parliamentary elections, separately listing estimates for center-left, other (center-small), center-right and anti-immigration

\footnotetext{
${ }^{29}$ The effect of refugee allocation on native net outflow is 0.149 with a standard error of 0.363 .
} 
parties. Panels A and B, respectively, report the results with each municipality given either equal weight or weighted by population size.

Estimates in Panel A suggest a considerable positive effect of refugee allocation on vote shares not only for the anti-immigration parties but also for center-right parties, while vote shares for the center-left parties and small center parties decline. Weighting the municipalities by population size (Panel B) greatly reduces both the magnitude and the precision of the results. Given that the large urban municipalities are weighted more, the difference in findings across panels must be the result of different voter responses to changes in the allocated refugee shares in urban municipalities.

To investigate this supposition further, we allow the voting response to differ between the 5 percent largest municipalities and all other municipalities (see Panel C). The estimates for all municipalities, except the largest, are now similar to the unweighted results in Panel A. For the 95 percent smaller municipalities, a one percentage point (one standard deviation) increase in allocation share increases the anti-immigration party vote share by $1.3(0.2)$ percentage points or, relative to their average 7.6 percent vote share, by 17.6 (3.2) percent. The center-right parties also gain 0.8 percentage point in vote share for each percentage point increase in refugee allocation over the previous four years, although their vote share is so large that this increase translates into a smaller percentage change. On the other hand, left-leaning centrist parties lose votes, as does the center left. In contrast, voters in the 5 percent largest municipalities respond to refugee allocation by reducing their votes for far rightleaning parties and increasing their vote share for center-left parties. A one-percentage point increase in refugee allocation decreases in these municipalities the vote share for anti-immigrant parties by 3.8 (5.1-1.3) percentage points. Our estimates therefore point to sharply different voter responses in rural and urban areas. 
Table $4 \mathrm{~b}$ reports the same estimates for municipal elections, which, like those for parliamentary elections, show refugee allocation increasing vote shares for anti-immigrant parties. Although this pattern is visible in both unweighted and weighted regressions, voting share responses to refugee inflows are again different in the largest municipalities with a voter tendency to reduce the vote share for anti-immigration parties and increase it for left-center parties. The overall effect of refugee allocation on vote shares for anti-immigration parties for large municipalities of -1.7 (last row of Panel C) is not significantly different from zero $(\mathrm{StdE}=1.7)$ but coefficient estimates for the more rural municipalities are larger than for parliamentary elections.

Our sample consists of 275 municipalities, and the 5\% largest municipality constitute 13 municipalities or 26 observations, so that estimates could be sensitive to outliers. To investigate the sensitivity of these results and the different response between small and large municipalities, we estimate equation (1-a) allowing $x$ (the percentile at which the dummy variable $D_{i x}$ switches to one) to vary from the $100^{\text {th }}$ to the $20^{\text {th }}$ percentile. We display, for the anti-immigration parties, estimates of $b_{1}$ and $b_{1}+b_{2}$ together with the $95 \%$ confidence intervals (vertical lines) in Panels A and B of Figure 3 for parliamentary and municipal elections respectively. Each dot in the graphs is based on a separate regression along the percentile distribution, where the upper series refers to the $(100-x)$ percent of the smallest municipalities, and the lower series to the $x$ percent largest municipalities. As a reference point, estimates at the vertical 5\% line refer to those in Panel C, column (4) in Tables 4a and 4b.

Panel A of the figure shows that the $b_{1}$ estimates for the $100-\mathrm{x} \%$ smaller municipalities are insignificant and small for $\mathrm{x}<2 \%$, but then stabilize around the estimate obtained for $\mathrm{x}=5 \%$, and remain remarkably stable when reducing the sample that identifies $b_{1}$ to smaller and smaller municipalities. The confidence interval includes the estimate at $x=5 \%$ (1.34) over the entire distribution. The lower 
series displays estimates for large municipalities, along the size percentiles $x$. Again, the vertical line at $x=5 \%$ corresponds to estimates in Panel C, Tables $4 \mathrm{a}$ and $4 \mathrm{~b}$. While estimates are very similar to those in Panel $\mathrm{C}$ between the $5^{\text {th }}$ and $15^{\text {th }}$ percentiles, they converge to the upper series, as smaller and smaller municipalities are added to identify $b_{1}+b_{2}$. Estimates for municipal elections in Panel B are similar, with the estimates for the $(100-x \%)$ smaller and more rural municipalities being very stable

over the entire range from the first to the $80^{\text {th }}$ percentile, and negative (but not significantly different from zero) for large and more urban municipalities. Based on these figures, we present all our estimates for the $95 \%$ more rural and the 5\% more urban municipalities.

\subsection{Robustness Checks and IV estimates}

In Table 5 we report estimates for a number of robustness checks. We focus on vote shares for antiimmigration parties and report full sets of estimates in Appendix Tables A11a and Table A11b. Columns 1 and 2 in Table 5 report estimates for parliamentary and municipal elections, respectively.

Panel A excludes Frederiksberg and Copenhagen (the two municipalities that constitute the capital) when computing the $5 \%$ largest municipalities, which were treated slightly differently in terms of allocation numbers due to their already large populations of non-Western immigrants. Their exclusion does not change the estimated coefficients much. In Panels B and C, we condition on available rental housing in the base period and on the change in the share of rental housing between election cycles. Again, estimates are similar to those in our base specification. Another concern may be that current economic shocks to the municipality lead to some spurious correlation between allocation shares of refugees and changes in vote shares. Our test for strict exogeneity in Section 4.1 re-assures us that this is not the case. Nevertheless, we report in Panels D and E estimates that condition 
on changes in gross income per capita, and on this variable and changes in available housing between electoral cycles. In both regressions, estimates are very similar to those in our base specification.

The estimates we report in Tables $4 \mathrm{a}$ and $4 \mathrm{~b}$ are ITT estimates, measuring the effect of allocated refugees on vote shares. These causal estimates are important policy parameters, allowing direct assessment of the impact of allocation policies on voting outcomes. One may also be interested, however, in the effect of changes in the share of resident refugees on voting outcomes. This parameter can be computed as a simple Wald estimator by dividing the ITT estimate through the first stage estimate when regressing changes in the share of resident refugees on changes in the share of allocated refugees. The IV estimator is causal if one is willing to make the additional exclusion assumption that the change in the share of allocated refugees affects voting outcomes only through the change in the share of resident refugees, and it can be interpreted as a local average treatment effect (LATE). We report estimates in Table 6, for parliamentary (Panel A) and municipal (Panel B) elections where we now present the net effect for the large municipalities (i.e. $b_{1}+b_{2}$ ). The first column reports the first stage, which is slightly below one for the more rural areas and above one in the urban areas. This reflects that - after allocation - refugees tend to move from rural municipalities to urban municipalities. As a result, the IV estimates are slightly larger than the ITT estimates in the rural and numerically smaller in the urban municipalities. We further compute Wald estimates on voting outcomes of changes in the share of non-western immigrants, instrumented with the share of allocated refugees (these results are available at request). First stage estimates are slightly above one for both urban and rural municipalities, which translates into a slightly smaller effect on voting outcomes. 


\subsection{Electoral Outcomes and Municipality Characteristics}

In Table 7, we investigate whether municipal characteristics affect electoral outcomes by interacting changes in allocation share with pre-policy (1985) municipal characteristics for parliament (columns 1-3) and municipal (columns 4-6) elections, based on estimates of equation (2). In addition to the share of immigrants, log gross income per capita, and the share of rich in the local population (Panels B-D), these characteristics include crime rates, measured as the number of reported crimes divided by the number of inhabitants (Panel E). They also include support for the Christian church, measured as the percentage of inhabitants who paid church taxes (Panel F), municipal unemployment rate (Panel G), the share of welfare dependent among immigrants $($ Panel H), and the share of tertiary educated (Panel I). We demean these variables and normalize them by their standard deviation, so that the coefficient in the second row of each panel can be interpreted as the additional effect of a one-percentage point increase in refugee allocation on the vote share of anti-immigrant parties in municipalities with a one standard deviation higher realization of the respective municipal characteristic. Panel A repeats as a reference the base estimates from Tables 4, Panel C. Columns (1) and (4) present results for the 95\% more rural municipalities, columns (2) and (5) for the 5\% more urban ones, and columns (3) and (6) compute the 5\% more urban municipalities omitting Copenhagen and Frederiksberg.

Focusing first on column (1), estimates in panel B suggest that electoral outcome responses to the refugee allocation vary strongly with the 1985 share of immigrants. If that share increases by one standard deviation at the mean, then the effect of a one-percentage point increase in the refugee allocation share increases from 1.3 to 3.6 percentage points. Thus, the presence of immigrants in the municipality greatly exacerbates the impact of refugee allocation on the anti-immigration party vote share, a finding in line with group threat theories (see Section 3.1). 
Furthermore, the effect of refugee allocation on anti-immigration party vote shares increases with $\log$ income per capita and the percentage of rich in the population (Panels C and D). This is in line with the economic hypothesis of self-interest, which posits that individuals respond to immigration based on their own economic concerns. The high welfare dependency of immigrants illustrated in Table 2 may lead the more affluent to believe that it is they who are mainly financing refugees. In line with this, the share of welfare dependents among immigrants increases the impact of refugee allocation on the vote share for anti-immigrant parties (see Panel H). These results echo Dustmann and Preston's (2005) analysis of the effect of labor market and fiscal burden concerns on attitudes towards immigration, which emphasizes that fiscal concerns are clearly dominant. Estimates with respect to crime suggest substantially increased sensitivity to refugee allocation in municipalities that were more exposed to crime before policy implementation. If the number of reported crimes is one standard deviation higher in the pre-allocation year, the same increase in refugee share leads to a tripling (from 1.2 to 3.4$)$ in the percentage point increase in vote shares for anti-immigration parties relative to the mean of crime rates. Panel F then reports the results of interacting these same estimates with the share of church taxpayers. They suggest that an increased allocation share leads to weaker effects on the vote shares of anti-immigration parties when the share of church taxpayers is higher. One way to interpret these findings is a more emphatically altruistic attitude towards refugee allocation in municipalities where support for Christianity is greater, making voters less responsive to anti-immigration party rhetoric. This is in line with Card, Dustmann and Preston's (2012) suggestion that altruistic attitudes lead to a more liberal voter position towards immigration. Interacting refugee allocation with unemployment rate (panel G) or the share of tertiary educated (panel I) reveals no significant vote share response. Estimates for municipal elections (column 4) are largely similar, although sometimes estimated with less precision. 
Considering the vote share responses of other parties (results are reported in Table A12a and Table A12b) shows that the exacerbation in vote share gains for anti-immigrant parties induced by particular pre-policy characteristics such as the share of immigrants is mirrored by losses for centerleft parties. For instance, a one standard deviation increase in the share of immigrants living in the municipality before implementation of the policy increases the percentage point gain of vote shares of anti-immigrant parties of a one-percentage point increase in refugee allocation by 2.3 . At the same time, however, it decreases the vote share for center left parties by 2.1 for parliament elections.

Columns (2) and (3) as well as columns (5) and (6) of Table 7 display results using the same set of municipal characteristics for only the 5 percent largest Danish municipalities calculated (in columns (3) and (6)) by excluding Copenhagen and Frederiksberg. If anything, these estimates indicate that immigrant pre-policy welfare dependency and share of immigrants in the population play little role in how urban voters react to refugee allocation, much in contrast to more rural municipalities. Likewise, the share of more affluent and the share of rich, rather than augmenting the allocation effect on antiimmigration party vote shares, points to the opposite. The one variable that seems to result in an allocation-induced increase in the far right vote share is municipal unemployment rate, which increases support for anti-immigration parties as refugee immigration increases.

Overall, estimates in Table 7 indicate (in particular for the 95\% more rural municipalities) a remarkable and often large heterogeneity in vote share responses to refugee allocations, according to pre-policy municipal characteristics.

Can these differences in vote share responses to refugee allocation explain the rural-urban divide we discuss in Section 4.3? Casual inspection of Tables 2 and 7 suggest that this is unlikely: Differences between rural and urban municipalities in many of the pre-municipal characteristics are quite small, and where they are large (such as the pre-policy share of immigrants), they likely exacerbate the vote 
share gap between rural and urban municipalities. We show this more formally in Table A13, where we compute for each of the pre-policy municipal characteristics the response of rural (urban) municipalities to refugee allocation if they were characterized by the mean of urban (rural) pre-policy characteristics. For instance, if rural municipalities had the same pre-policy share of immigrants as urban municipalities, their vote share response for anti-immigrant parties to a one-percentage point increase of allocated refugees would increase from 1.3 to 4.2 percentage points in parliament elections. Thus, the difference between rural and urban municipalities is due to differences in response behavior, something we investigate in more detail below.

\subsection{Refugee Allocation and Voter Turnout}

The results above suggest that the anti-immigration party vote share is indeed sensitive to inter-cycle allocation of refugees. This could be because voters respond to allocation by casting their votes for anti-immigration parties, or because voter composition itself changes through the activation of those who would otherwise not vote. Therefore, although we cannot directly test such an effect on voter composition (because we have no individual data on voting behavior), we explore whether refugee allocation activates additional voter participation by investigating whether it affects voter turnout. As shown in Table 1, over the three parliamentary (municipal) electoral cycles considered here, on average 84 percent (70 percent) of eligible voters participated in the elections, respectively. The average change in turnout between two parliamentary (municipal) electoral cycles is $1.54(1.25)$ percentage points. In Table 8 , we regress this turnout on the refugee share allocated to a specific municipality, showing the fixed effects estimates in Panel A and the difference estimates (change in voter turnout regressed on change in refugee allocation between previous and current electoral cycles) in Panel B. We report both weighted and unweighted estimates. 
These findings lend little support for the hypothesis that refugee allocation has a noticeable impact on voter turnout in parliamentary elections: the estimates in columns (1) and (2) are small and never statistically significant. For municipal elections, however, columns (3) and (4) show evidence that a higher share of allocated refugees leads to a higher share of individuals voting. More specifically, a one-percentage point increase in the refugee allocation share increases voter participation by between 0.6 and 2.0 percentage points. Thus, there is some evidence that voter turnout is affected by refugee allocation but this effect is restricted to municipal elections.

\subsection{The Decision to Run in Municipal Elections}

Because not every party stands for municipal election in every municipality, anti-immigration parties are often absent from such contests (see Table A14). Moreover, as previously explained, prior to the foundation of the DPP in 1995, the PP was the only party running with a strong anti-immigration agenda. In the 1997 municipal elections, the DPP ran alongside the PP in 116 municipalities. Of the two parties, only the PP ran in 80 municipalities and only the DPP ran in 26 municipalities and neither of the two parties ran in 53 municipalities. The decision where to run is thus an interesting outcome variable in itself which we now investigate.

In Table 9, we perform an initial assessment of how anti-immigration parties may decide whether and where to stand for municipal elections in response to inter-cycle allocation shares. Specifically, this table reports linear probability models with the first column listing the effect of refugee allocation on the probability that either of the two parties stands in a given municipality in either the 1993 or 1997 municipal election. ${ }^{30}$ The average share of municipalities in which at least one anti-immigration party

\footnotetext{
${ }^{30}$ The marginal effects from probit models (evaluated at the mean) are almost identical.
} 
is running for election is 77 percent. The results in the table therefore suggest that a one standard deviation (0.18) increase in the change in refugee allocation increases the probability of an antiimmigration party running by 5.8 percentage points or 7.5 percent. The next two columns report the results of running the same regression for the 1997 election only (when both anti-immigration parties were present) with the probability of at least one party or both parties running in a municipality as the dependent variable. The effects for that year are even larger: A one standard deviation increase in the allocation share increases the probability of at least one anti-immigration party running by 7 percentage points and that of both parties running by 12 percentage points. Refugee allocation thus seems to be a powerful predictor of anti-immigration parties running in local elections.

\section{Explaining Differences between Urban and Rural Municipalities}

A striking finding of our analysis is the difference in how voters respond to refugee allocation in rural and urban municipalities. We show in Section 4.5 that these differences cannot be explained by differences in municipal characteristics. We now explore this further by investigating whether attitudes towards refugees and immigrants differ between urban and rural populations and whether any such differences are due to differences in the composition of populations in terms of education and demographic structure. We also investigate whether exposure to refugee and immigrant populations differs between urban and rural areas as a possible channel that explains the differences in voting responses we illustrate above.

\subsection{Voting and Attitudes towards Refugees and Immigrants}

Our analysis is based on various waves of the Danish National Election Survey (DNES) contemporary to our elections, and the first (2002) wave of the European Social Survey (ESS) for Denmark, which contains a special module on immigrants and refugees (see Card et al. 2005). We 
describe both surveys and questions used in Appendix B. Below we first investigate whether views about refugees are associated (on an individual basis) with voting for an anti-immigrant party. We then explore whether attitudes towards refugees differ in rural versus urban areas and to what extent this can be explained by differences in demographic composition.

In the DNES, 5.5 percent of interviewees respond that they voted for an anti-immigration party (see Appendix Table A15). In Panel A of Table 10, we report regressions of an indicator variable if the individual voted for an anti-immigration party on responses to questions that reflect views on refugees or immigrants. These attitudes are measured on a five-point scale, and we normalize them between 0 and 1, where 1 reflects the most "pro" category. In the table, unequal column numbers report unconditional regressions, and equal column numbers present regressions that condition on education, age and gender. The estimates show a strong association between sympathetic views towards immigrants and refugees, and reduced probabilities to vote for an anti-immigration party. Views that more money should be spent on refugee support, that immigrants constitute no threat to the Danish culture, that refugees should have the same access to social benefits than Danes, and that Denmark could receive more refugees are all strongly and negatively associated with voting for an antiimmigration party. Moving from the most hostile (0) to the most sympathetic (1) category on the scale of attitudes decreases the probability to vote for an anti-immigration party by between 11 and 24 percentage points which is a large response, given the mean vote share of 5.5 percent for such parties.

Estimates presented in Panel B of Table 10 illustrate a sharp divide in attitudes between urban and rural areas. While for instance the mean of the normalized response of how many additional refugees Denmark can receive (bound between the extremes 0 and 1 ) is 0.36 , it is 0.06 points (or 17\%) higher in urban than in rural areas. Rural-Urban differences in other attitudes are of similar magnitude. Differences in composition can partly explain this, as suggested by the smaller estimates when 
conditioning on demographic characteristics, which decrease by between 43 and 58 percent. ${ }^{31}$ Thus, respondents form urban areas hold more sympathetic views about refugees and immigrants, which in turn are strongly associated with probabilities to vote for anti-immigration parties.

\subsection{Contact with Immigrants and Segregation}

One reason for the observed differences in attitudes could be differential exposure of native residents to those of different background. In which direction such exposure moves attitudes may be related to whether any such contact is deliberate and fulfils Allport's (1954) four conditions (see Section 3.1), or is felt as being imposed, triggering perceptions of threat to indigenous culture and identity and negative prejudice, as suggested by group threat theories. Using information in the ESS, we find that those living in cities are 14 and 16 percentage points (30 and 31 percent) more likely to have an immigrant as friend or work colleague respectively. Moreover, having an immigrant friend or colleague is associated with far more positive attitudes towards refugees (we report estimates in Table A18). Such friendship and workplace contact fulfils Allport's (1954) criteria of equal group status, common goals, intergroup cooperation and authority support, and thus may reduce prejudice in cities.

However, exposure to refugees in one's neighborhood that is felt as a result of imposed settlement policies may trigger opposite responses. We next investigate whether such exposure is higher in rural than in urban areas by computing an index of residential segregation for refugees and non-western immigrants and their descendants, which measures the degree to which natives are exposed to refugees in their neighborhood (the "interaction index"; see Lieberson, 1981). To achieve that, we follow Damm

\footnotetext{
${ }^{31}$ In Table A17, we present additional analysis based on a more extensive set of questions regarding refugees from the 2002 ESS. These include whether asylum seekers' applications should be looked at more generously, whether they should receive financial support, whether they should be allowed to work, or bring their families, whether Denmark receives more than its fair share of refugees, whether refugees are indeed persecuted, and whether asylum seekers should be detained while their cases are considered. While the ESS data does not provide us with a municipal identifier, we do observe whether the respondent lives in a big city. We find that individuals living in big cities respond far more sympathetic to each of these questions and that only part of this difference is explained by composition.
} 
and Schultz-Nielsen (2008) and split Denmark's entire area into 9,400 neighborhoods (computed by aggregating 431,000 geo-referenced hectare cells, obtaining compact neighborhood clusters), each containing around 200 households with an average population of about 500. In samples of different sizes, random allocation generates substantial unevenness (and hence segregation) sensitive to sample size. We follow Carrington and Troske (1997) and modify the index normalizing it by the unevenness generated through random allocation alone. ${ }^{32}$ The resulting adjusted index measures the extent to which segregation is larger (or smaller) than what we would expect from random allocation.

Table 11 displays the adjusted indices for allocated refugees (row 1) and non-Western immigrants (row 2). They suggest that exposure of residents to refugees and non-Western immigrants is higher across neighborhoods in rural than it is in urban municipalities. The degree to which natives are exposed to refugees in urban areas is about $20 \%$ lower than what random allocation would suggest, while it is only $10 \%$ lower in rural municipalities. Overall, therefore, exposure to refugees and nonWestern immigrants that is likely to be involuntary tends to be larger in rural areas.

To investigate whether segregation may contribute to shaping attitudes towards refugees, we next regress the four attitudes measures in the DNES on the municipality-specific interaction index. We find a strong association between exposure to refugees in one's immediate neighborhood and negativity of attitudes towards refugees (see Table 12). We also find a positive (but insignificant) relation between our exposure measure, and the probability that the responded reports to have voted for an antiimmigration party. Thus, and in line with group threat theories, differences in exposure to refugees in

\footnotetext{
${ }^{32}$ We randomly assign the population residing in each municipality to neighborhoods keeping neighborhood size constant and compute indices based on the mean of 500 repetitions for each municipality. We then adjust the index to be measured relative to segregation under randomness by computing the measure of systematic interaction as $\frac{I-I_{r}}{I_{r}}$, where $I$ is the standard interaction index and $I_{r}$ is the same index corresponding to random allocation. See Carrington and Troske (1997) for details.
} 
one's neighborhood may be one channel that leads to prejudice and ultimately different sensitivity of voting behavior to additional refugee allocations in urban and rural municipalities.

\section{Discussion and Conclusions}

By exploiting data covering the 13 years of Denmark's random refugee dispersal policy, which encompass three parliamentary and municipal electoral cycles, we show that an exogenous increase in refugee allocation strongly affects anti-immigration parties' vote shares in both parliamentary and municipal elections in all but the most urban municipalities. Although anti-immigration parties gain most from refugee allocation, we also find an increase in the vote shares of center-right parties but a clear reduction in those of left-leaning parties. Interestingly, this response is not evident in Denmark's urban areas in which the impact of refugee allocation points, if anything, in the opposite direction.

We also find strong evidence for heterogeneity in anti-immigration party voting responses across municipalities to refugee allocation. In the smaller and rural municipalities, pre-policy characteristics such as the share of immigrants, gross income, the share of rich, the crime rate and the share of welfare dependent immigrants all exacerbate the effect of the same allocation of refugees on vote shares for anti-immigration parties with large effect sizes. This is strong evidence that municipalities with different characteristics respond differently to refugee allocation in the sense that they turn their votes to anti-immigration parties. We further establish that refugee allocation is strongly related to antiimmigration parties' decisions on where to stand in municipal elections.

One intriguing result of our analysis is that the effect of refugee allocation on vote shares for antiimmigration parties is largely absent in urban municipalities, a response difference that cannot be explained by differences in pre-policy municipal characteristics. This revelation underscores Barone et 
al.'s (2016) findings for Italy and reconciles the majority research conclusion that immigrant shares unanimously strengthen the vote share of the extreme right with Steinmayr's (2017) finding of the opposite. ${ }^{33}$ Investigating possible reasons for such differential responses, we show that individuals who live in cities have more positive attitudes towards refugees and immigrants than those living in rural areas, and that these attitudes are strongly related to voting behavior. We also find that those in urban areas are more likely to have immigrants among their colleagues or friends, which is in turn strongly associated with more positive attitudes towards refugees. Thus, contact with foreign born in a workplace or leisure environment as friends or colleagues likely meets Allport's (1954) conditions for contact as a means of prejudice reduction. On the other hand, we also show that those in rural areas are more likely to be exposed to refugees and non-Western migrants in their immediate neighborhood. This involuntary exposure may enhance the perceived threat from these communities, exacerbate negative attitudes, and ultimately influence the sensitivity of voting behavior to further allocations. Indeed, we provide evidence that larger exposure is associated with negativity of attitudes towards refugees.

Our paper contributes to a better understanding for the rise of populist parties and politicians and of the reasons for different voter responses. Our study is the first that uses an assignment experiment to provide causal evidence that refugee migration leads not only to an increase in the share of votes for anti-immigrant parties, but may be the main factor for the emergence of these parties in elections. Our strong evidence of response heterogeneity based on municipal characteristics, and the evidence that refugee allocation may lead to very different responses in urban versus rural areas has important

\footnotetext{
${ }^{33}$ It also is in line with observational evidence of stark divides between rural and urban elections in recent years, such as between London and the rest of the UK in the popular vote for the UK Independence Party (UKIP) in the European (2014) and general (2015) elections. Similarly, in the Finnish 2015 parliamentary elections, the anti-immigrant (True) Finns party (Perussuomalaiset) had the lowest support in Helsinki, while in the Belgian regional and federal elections of 2014, the antiimmigrant Flemish Interest party (Vlaams Belang) had the lowest share of supporters in the region around Brussels.
} 
implications for the current debate on refugee allocation in Europe. It suggests that allocation practices that take municipal characteristics into account, rather than random allocation based on equalizing the share relative to the resident population, may be preferable as they mitigate the emergence of radical parties. We also provide novel evidence that may explain the divide between rural and urban populations in attitudes and ultimately voting patterns. These findings have immediate relevance for the policy debate. 


\section{References}

Allport, Gordon W., “The Nature of Prejudice”, Reading, MA: Addison-Wesley, (1954).

Altonji, Joseph G. and Card, David, "The effects of immigration on the labor market outcomes of lessskilled natives", in John M. Abowd (ed.), Immigration, Trade and Labor, Chicago: The University of Chicago Press, (1991).

Andersen, Jørgen Goul and Bjørklund Tor, "Structural change and new cleavages: the Progress Parties in Denmark and Norway", Acta Sociologica, 33(3) (1990), 195-217.

Barone, Guglielmo, D'Ignazio, Alessio, de Blasio, Guido and Naticchioni, Paolo, "Mr. Rossi, Mr. Hu and politics: the role of immigration in shaping natives' political preferences", Journal of Public Economics 136 (2016): 1-13.

Betz, Hans-Georg and Johnson, Carol, “Against the current - stemming the tide: the nostalgic ideology of the contemporary radical populist right”, Journal of Political Ideologies, 9(3) (2004), 311327.

Blalock, Hubert M., “Toward a Theory of Minority Group Relations," New York: Capricorn Books, (1967).

Blumer, Herbert, "Race prejudice as a sense of group position”, Pacific Sociological Review, 1 (1958), $3-7$.

Bobo, Lawrence, "Whites' opposition to busing: symbolic racism or realistic group conflict?", Journal of Personality and Social Psychology, 45 (1983), 1196-1210.

Bradburn N, Sudman S, Gockel GL. 1971. Side by Side: Integrated Neighborhoods in America. Chicago: Quadrangle Books.

Brooks D. 1975. Race and Labour in London Transport. London: Oxford Univ. Press. 
Brunner, Beatrice and Kuhn, Andreas, "Immigration, cultural distance and native' attitudes towards immigrants: evidence from Swiss voting results”, IZA Discussion Paper No. 8409, (2014).

Campbell, Donald T., "Ethnocentric and other altruistic motives", in David Levine (ed.), Nebraska Symposium on Motivation, Lincoln: University of Nebraska Press, (1965).

Campbell, Andrea L., Citrin, Jack and Wong, Cara, "Racial threat, partisan climate, and direct democracy: contextual effects in three California initiatives", Political Behavior, 28(2) (2006), $129-150$.

Card, David, "Immigrant inflows, native outflows, and the local labor market impacts of higher immigration", Journal of Labor Economics 19(1) (2001), 22-64.

Card, David, Dustmann, Christian and Preston, Ian, "Immigration, wages, and compositional amenities," Journal of the European Economic Association, 10(1) (2012), 78-119.

Card, David, Dustmann, Christian and Preston, Ian, "Understanding attitudes to immigration: The migration and minority module of the first European Social Survey," CReAM Discussion Paper 03/05 (2005).

Carrington, William J., and Kenneth R. Troske. "On measuring segregation in samples with small units." Journal of Business \& Economic Statistics 15(4) (1997). 402-409.

Citrin, Jack, Green, Donald P., Muste, Christopher and Wong, Cara, "Public opinion toward immigration reform: the role of economic motivations", Journal of Politics, 59 (1997), 858881.

Dahlberg, Matz, Edmark, Karin and Lundqvist, Heléne, "Ethnic diversity and preferences for redistribution", Journal of Political Economy, 120(1) (2012), 41-76. 
Damm, Anna P. and Marie L. Schultz-Nielsen, "Danish Neighbourhoods: Construction and Relevance for Measurement of Residential Segregation", Danish Journal of Economics (Nationaløkonomisk Tidsskrift),146(3) (2008), 241-262.

Danish Refugee Council, “Annual Report”, Copenhagen, (1987).

Danish Refugee Council, Central Integration Unit (CIU), “Dansk Flygtningehjaelps integrationsarbejde [Danish Refugee Council's integration work]", Copenhagen, (1996).

Dansk Folkeparti, "Dansk Folkepartis Principprogram [Danish People's Party Program of Principles]", Christiansborg, (1997).

Downs, Anthony, “An Economic Theory of Democracy”, New York: HarperCollins, (1957).

Dustmann, Christian and Preston, Ian P., "Attitudes to ethnic minorities, ethnic context and location decisions", Economic Journal, 111 (2001), 353-373.

Dustmann, Christian and Preston, Ian P., "Is immigration good or bad for the economy? Analysis of attitudinal responses", Research in Labor Economics, 24 (2005), 3-34.

Dustmann, C., Fasani, F., Frattini, T. Minale, L. and Schönberg, U., "On the economics and politics of refugee migration”, Economic Policy, 32(91) (2017), 497-550.

Esses, Victoria M., Dovidio, John F., Jackson, Lynne M. and Armstrong, Tamara L., “The immigration dilemma: the role of perceived group competition, ethnic prejudice, and national identity", Journal of Social Issues, 57 (2001), 389-412.

Facchini, Giovani and Mayda, Anna M., "Does the welfare state affect individual attitudes toward immigrants? Evidence across countries", Review of Economics and Statistics, 91(2) (2009), 295-314.

Folketinget, "Parliamentary Election Act of Denmark", Ministry of Social Welfare and Folketinget, Parliament of Denmark, Copenhagen, (2009). 
Gerdes, Christer and Wadensjö, Eskil, "The impact of immigration on election outcomes in Danish municipalities”, working paper, Stockholm University Linnaeus Centre for Integration Studies (SULCIS), 2010(3) (2010).

Givens, Terri E., "Voting Radical Right in Western Europe”, Cambridge: Cambridge University Press, (2012).

Halla, Martin, Wagner, Alexander F. and Zweimüller, Josef, "Immigration and voting for the extreme right", Journal of the European Economic Association (2017): jvw003.

Harmon, Nikolaj A., "Immigration, ethnic diversity and political outcomes: evidence from Denmark", The Scandinavian Journal of Economics, (2017).

Jensen, Carsten and Frølund Thomsen, Jens P., "Can party competition amplify mass ideological polarization over public policy? The case of ethnic exclusionism in Denmark and Sweden", Party Politics, 19(5) (2013), 821-840.

Key, V. 0. (1984 [1949]). Southern politics in state and nation. Knox ville: University of Tennessee Lahav, Gallya, "Public opinion toward immigrants in the European Union: does it matter?", Comparative Political Studies, 37 (2004), 1151-1183.

Levine, Robert A., and Campbell, Donald T., “Ethnocentrism”, New York: John Wiley, (1972).

Lieberson, Stanley, “An Asymmetric Approach to Segregation”, in Ethnic Segregation in Cities, Ceri Peach, Vaughn Robinson and Susan Smith (ed). Croom Helm, (1981).

Lubbers, Marcel, Gijsberts, Merove and Scheepers, Peer, "Extreme right-wing voting in Western Europe”, European Journal of Political Research, 41(3) (2002), 345-378.

Mendez, Ildefonso and Isabel M. Cutillas, "Has immigration affected Spanish presidential elections results?". Journal of Population Economics, 27(1) (2014)135-171. 
Ministry of the Interior, "Baggrund for redegørelse/handlingsplan for Danmarks Udlændinge", Indenrigsministeriet (1993).

Norris, Pippa, "Radical Right: Parties and Electoral Competition", Cambridge: Cambridge University Press, (2005).

Otto, Alkis H. and Steinhardt, Max F., "Immigration and election outcomes: evidence from city districts in Hamburg", Regional Science and Urban Economics, 45 (2014), 67-79.

Pettigrew, Thomas F., "Intergroup contact theory", Annual Review of Psychology, 49(1) (1998), 6585.

Quillian, Lincoln, "Prejudice as a response to perceived group threat: population composition and antiimmigrant and racial prejudice in Europe”, American Sociological Review, 60 (1995), 586611.

Rasmussen, Søren H, "Da Fremskridtspartiet blev fremmedsmodstander [When the Progress Party became the opponent of foreigners]", Siden Saxo, 1 (2004), 14-23.

Ruist, J., Stuhler, J. and Jaeger, D., "Shift-share instruments and the impact of immigration", Working Paper, (2017).

Rydgren, Jens, "Explaining the emergence of radical right-wing populist parties: the case of Denmark", West European Politics, 27(3) (2004), 474-502.

Rydgren, Jens, "Radical right-wing populism in Denmark and Sweden: explaining party system change and stability", SAIS Review, XXX(1) (2010), 57-71.

Scheve, Kenneth F. and Slaughter, Matthew J., "Labor market competition and individual preferences over immigration policy", Review of Economics and Statistics, 83 (2001), 133-145.

Sidanius, Jim and Pratto, Felicia, "Social Dominance: An Intergroup Theory of Social Hierarchy and Oppression”, New York: Cambridge University Press, (1999). 
Simonsen, Tor E., "Høyrepopulismens politiske metamorphose på 1990-tallet. En komparativ studie af tre nordiske partier: Fremskridtspartiet, Dansk Folkeparti og Fremskridspartiet [The political metamorphose of the right-wing populism in the 1990s. A comparative study of three Nordic parties: the Progress Party, the Danish People's Party and the Progressive Party]", master's thesis, Institute for Archeology, Conservation and History, University of Oslo, (2007).

Steinmayr, A, "Exposure to refugees and voting for the far right. (Unexpected) results from Austria", March 7, (2017).

Taylor, Marylee C., "How White attitudes vary with the racial composition of local populations: numbers count", American Sociological Review, 63 (1998), 512-535.

Wooldridge, Jeffrey M., "Econometric analysis of cross section and panel data." Cambridge: MIT Press, (2010). 
Figure 1. Danish Elections, Governments and Anti-immigration Parties in 1986-1998

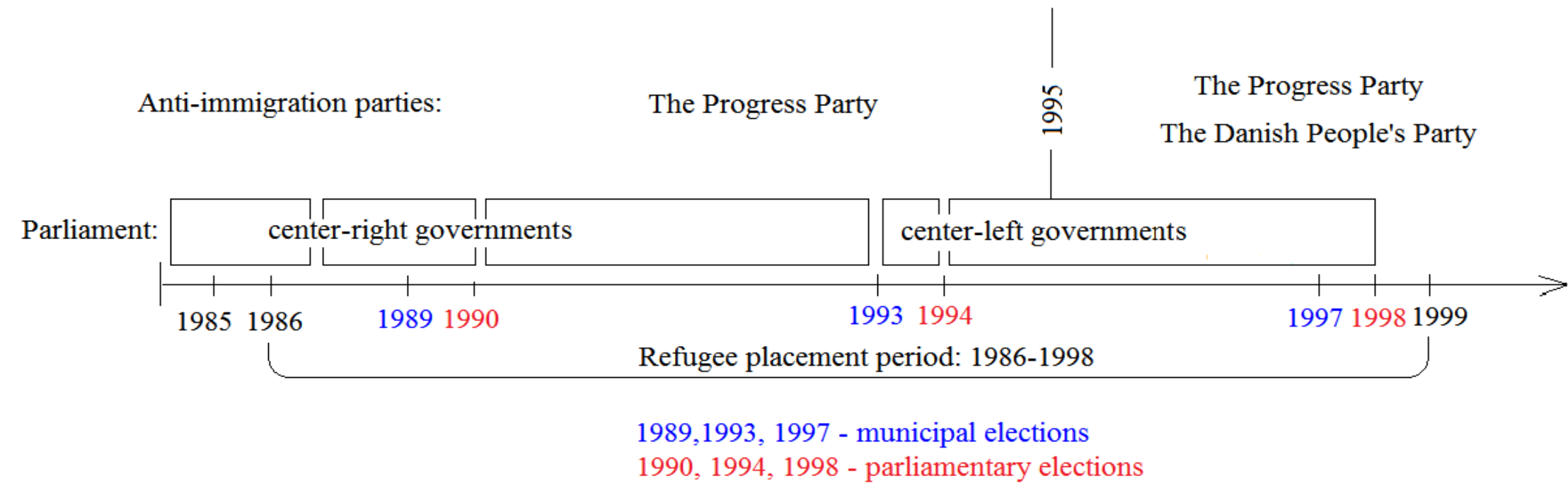


Table 1. Voting Outcomes

\begin{tabular}{|c|c|c|c|c|}
\hline & \multicolumn{2}{|c|}{ Parliament Elections } & \multicolumn{2}{|c|}{ Municipality Elections } \\
\hline & Mean & Std. Dev & Mean & Std. Dev \\
\hline Vote share for: Anti-immigration parties (PP and DPP) & 7.60 & 2.84 & 5.58 & 3.29 \\
\hline The Progress Party & 5.12 & 3.11 & 3.85 & 3.14 \\
\hline Centre-left parties & 51.19 & 9.61 & 48.36 & 13.10 \\
\hline Centre-right parties & 34.28 & 8.45 & 35.64 & 12.23 \\
\hline Other (centre small) parties & 6.93 & 2.38 & 10.42 & 9.75 \\
\hline Turnout & 84.28 & 2.68 & 69.71 & 5.64 \\
\hline Election cycle change in turnout & 1.54 & 0.88 & 1.25 & 2.98 \\
\hline
\end{tabular}

Note: Danish Parliament elections 1990-1998. Danish municipal elections 1989-1997. Voting statistics from the Danish Ministry of the Interior, Statistics Denmarks Database, Statistical Yearbooks for municipal elections, and the "Municipal elections in municipalities and counties on the 21st of November, 1989" statistical book. See Table A1 and Table A4 in the Appendix for vote shares broken down by election year and for a detailed description of data construction. Means are weighted by municipality population size in 1986 . 
Figure 2a. Allocated Refugees Versus Danish County Population

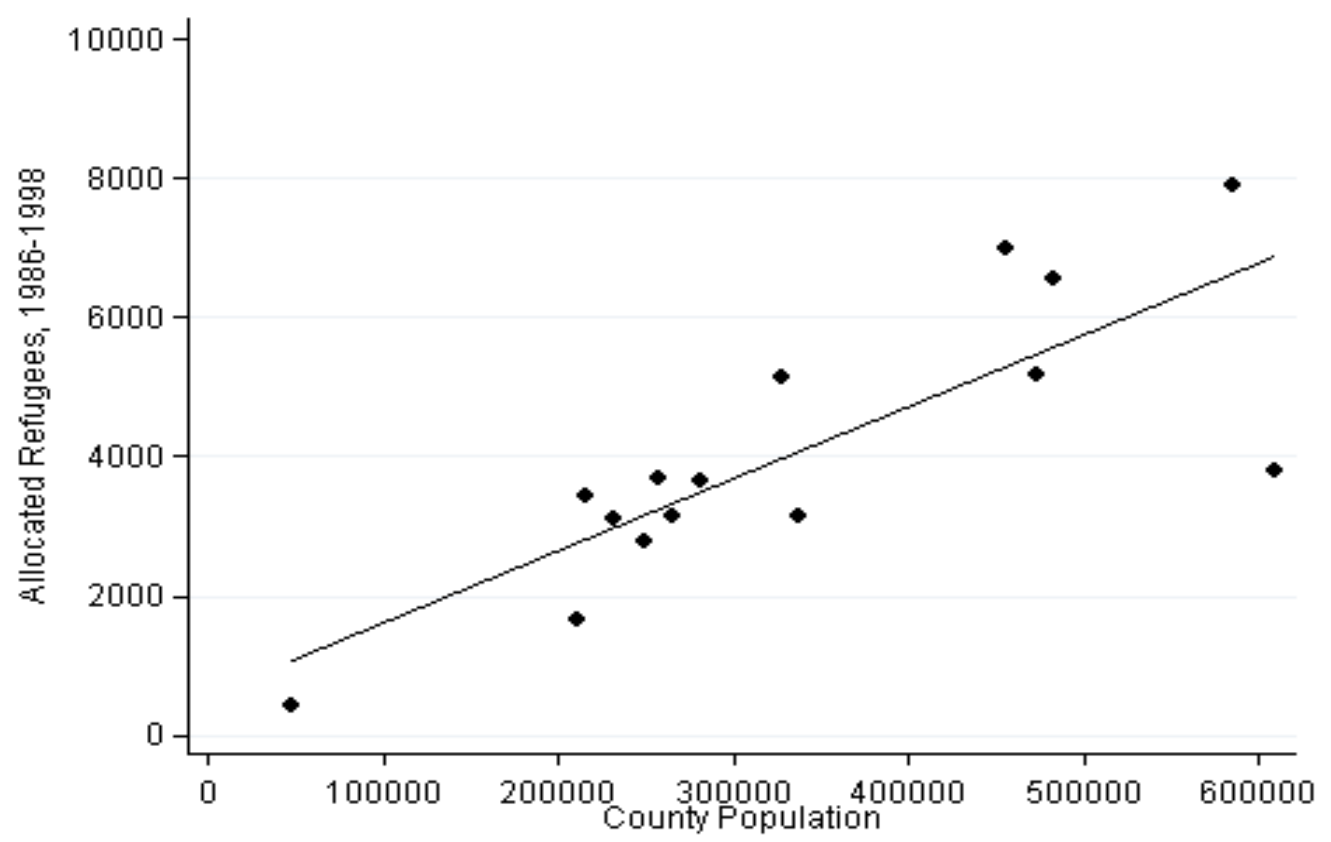

Source: Own calculations based on Statistics Denmark register data.

Note: Vertical axis: Number of refugees allocated between 1986 and 1998. Horizontal axis: local county population in 1986. Slope of the regression line: 0.0103 . 
Figure 2b. Allocated Refugees Versus Danish Municipal Population

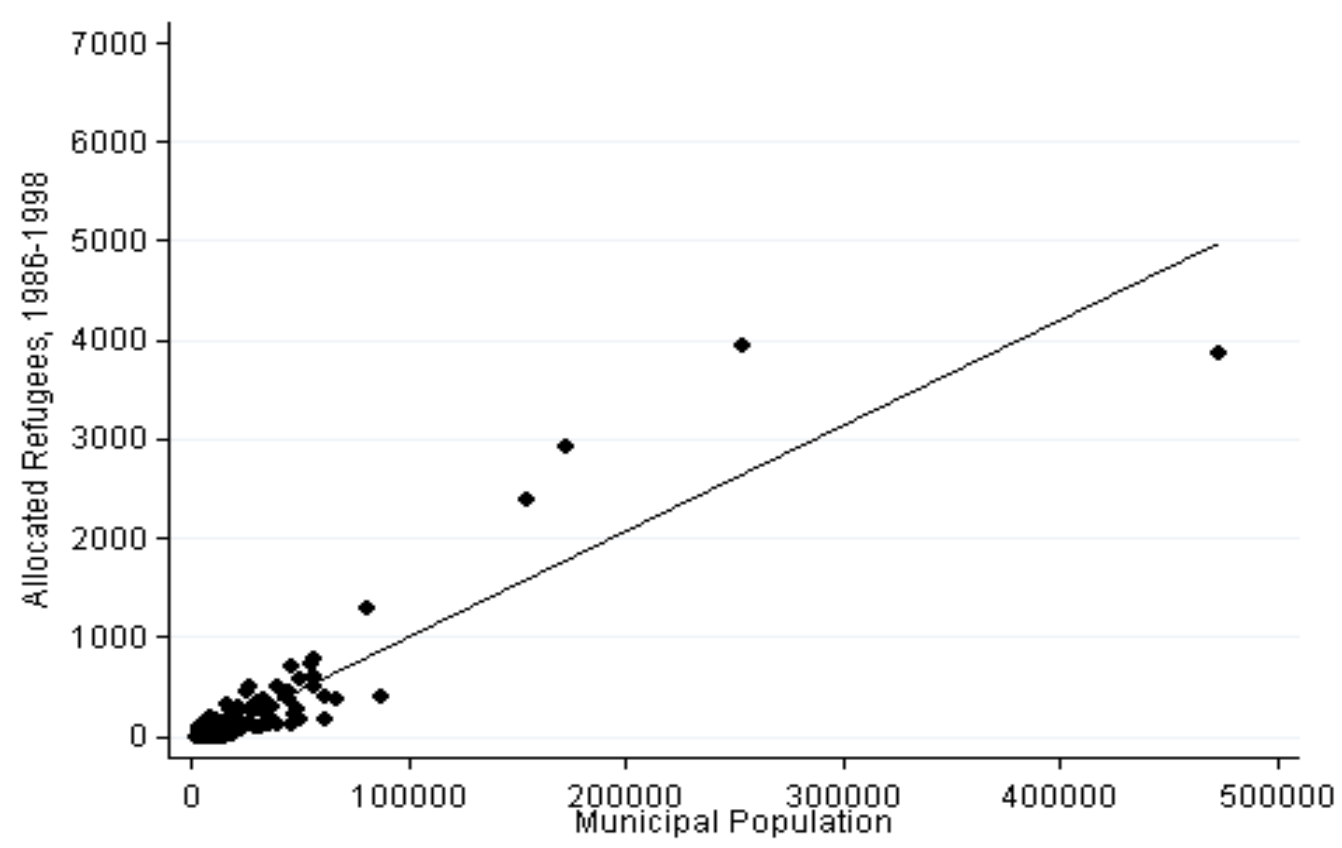

Source: Own calculations based on Statistics Denmark register data.

Note: Vertical axis: Number of refugees allocated between 1986 and 1998. Horizontal axis: local municipal population in 1986. Slope of the regression line: 0.0107. 
Figure 2c. Allocated Refugees Versus Municipal Population, 95\% Smallest Municipalities

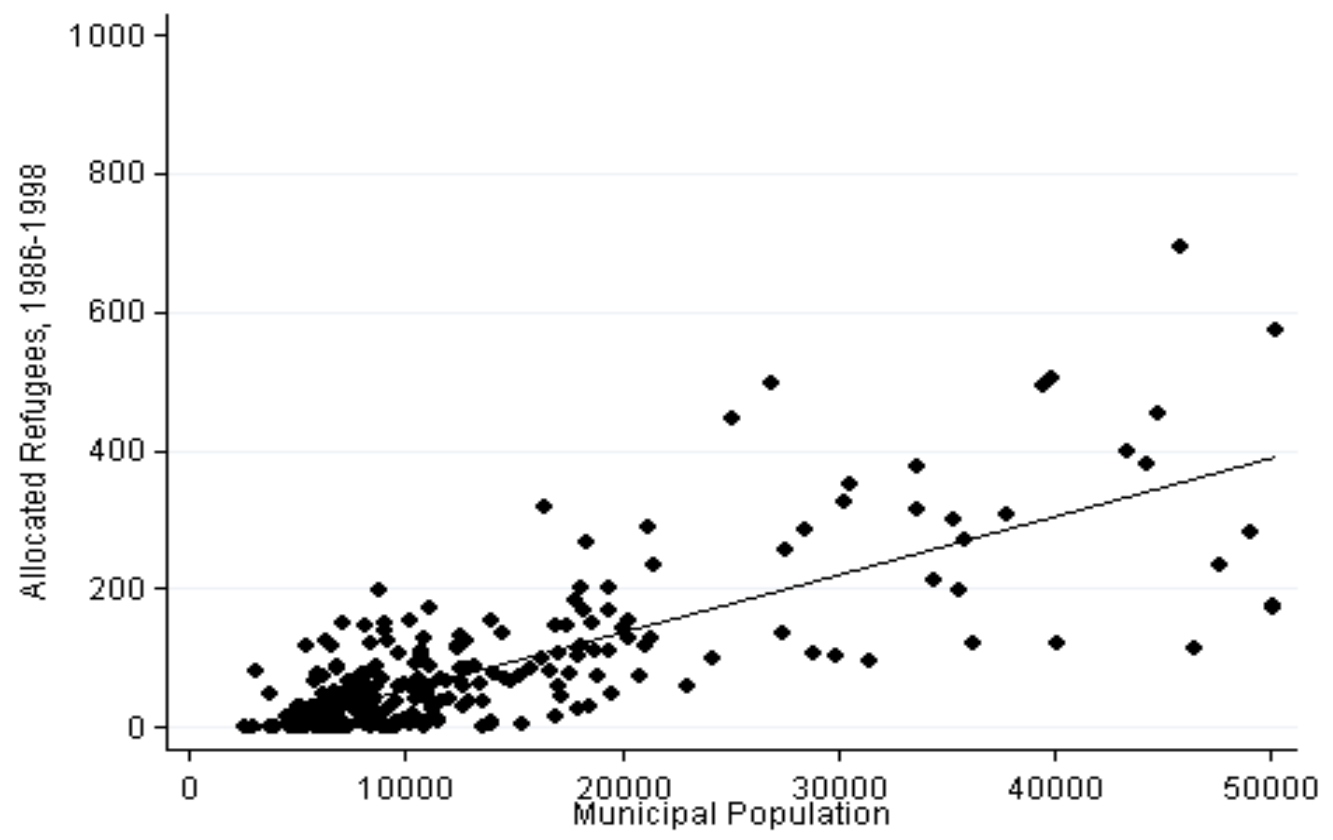

Source: Own calculations based on Statistics Denmark register data.

Note: Vertical axis: Number of refugees allocated between 1986 and 1998. Horizontal axis: local municipal population in 1986. Slope of the regression line: 0.0083 . 
Table 2. Summary Statistics

All municipalities $\quad$ Smallest 95\% Municipalities $\quad$ Largest 5\% Municipalities

\begin{tabular}{lcccccc}
\hline & \multicolumn{6}{c}{ Panel A: Municipal population size per 01.01.1986 } \\
\hline & Mean & Sd & Mean & Sd & Mean & Sd \\
\hline Population & 18604.19 & 36199.89 & 13282.26 & 10243.69 & 125861.62 & 120656.61 \\
\hline
\end{tabular}

Panel B: Municipal characteristics 1985. Weighted by municipal population size per 01.01.1986

\begin{tabular}{|c|c|c|c|c|c|c|}
\hline & Mean & $\mathrm{Sd}$ & Mean & $\mathrm{Sd}$ & Mean & $\mathrm{Sd}$ \\
\hline Mean log gross income per capita & 11.44 & 0.12 & 11.43 & 0.13 & 11.45 & 0.12 \\
\hline Mean age & 45.68 & 2.24 & 45.48 & 2.29 & 46.09 & 2.14 \\
\hline $\begin{array}{l}\text { Share of rich ( } 50 \% \text { above Danish median } \\
\text { income) in local population, } \%\end{array}$ & 14.48 & 6.19 & 15.26 & 6.50 & 12.84 & 5.29 \\
\hline $\begin{array}{l}\text { Share of immigrants (1st and 2nd } \\
\text { generation), \% }\end{array}$ & 3.27 & 2.55 & 2.40 & 1.86 & 5.12 & 2.91 \\
\hline Reported crime rate, $\%$ & 9.36 & 3.97 & 7.73 & 2.19 & 12.83 & 4.80 \\
\hline $\begin{array}{l}\text { Share of native population paying } \\
\text { voluntary church tax, } \%\end{array}$ & 83.22 & 3.90 & 84.70 & 2.66 & 80.07 & 4.38 \\
\hline Share of unemployed in labour force, $\%$ & 7.43 & 2.30 & 6.81 & 2.16 & 8.77 & 2.06 \\
\hline $\begin{array}{l}\text { Share of welfare dependent among } \\
\text { immigrants, } \%\end{array}$ & 48.98 & 7.26 & 46.58 & 7.41 & 54.10 & 3.16 \\
\hline $\begin{array}{l}\text { Share with a tertiary education among } \\
\text { those younger than } 65, \%\end{array}$ & 10.49 & 3.78 & 9.62 & 3.57 & 12.33 & 3.57 \\
\hline Share of vacant rental housing, $\%$ & 0.96 & 0.40 & 0.80 & 0.33 & 1.30 & 0.30 \\
\hline
\end{tabular}

Panel C: Refugee characteristics the year of immigration. Weighted by municipal population size

\begin{tabular}{lcccccc} 
& \multicolumn{5}{c}{ per 01.01.1986 } \\
$\begin{array}{l}\text { Upper Secondary or Primary school } \\
\text { Education }\end{array}$ & 0.17 & 0.10 & 0.16 & 0.12 & 0.18 & 0.03 \\
Primary School & 0.11 & 0.08 & 0.11 & 0.10 & 0.11 & 0.03 \\
Upper Secondary Education & 0.06 & 0.06 & 0.05 & 0.07 & 0.07 & 0.02 \\
Qualifying Education & 0.09 & 0.10 & 0.09 & 0.13 & 0.09 & 0.02 \\
Tertiary Education & 0.10 & 0.09 & 0.09 & 0.11 & 0.11 & 0.02 \\
Missing Education & 0.64 & 0.16 & 0.65 & 0.19 & 0.02 & 0.06 \\
Municipality Received 0 Refugees (0/1) & 0.13 & 0.33 & 0.18 & 0.39 & 0.00 & 0.00
\end{tabular}

Note: Municipality variables measured in 1985. Municipal characteristics are constructed from Population, Income, Education, Labour force and Socioeconomic registers owned by Statistics Denmark. Please see Table A4 for the detailed description of data construction. Means are weighted by municipality population size in 1986 . 
Table 3. Balancing Tests

\begin{tabular}{|c|c|c|c|c|}
\hline \multirow{2}{*}{$\begin{array}{l}\text { Dependent variable: } \\
\text { Explanatory variable: }\end{array}$} & \multicolumn{4}{|c|}{$\begin{array}{c}\Delta \text { Share of allocated refugees in } \% \text { of local population, } 4 \text { years after } \\
\text { election }\end{array}$} \\
\hline & Centre-Left & $\begin{array}{c}\text { Other (Centre } \\
\text { small) }\end{array}$ & Centre-Right & $\begin{array}{c}\text { Anti- } \\
\text { Immigration } \\
\end{array}$ \\
\hline & \multicolumn{4}{|c|}{ Panel A: Lagged vote shares } \\
\hline \multirow[t]{2}{*}{$\Delta$ Share of votes, lagged } & 0.0012 & $-0.0048 * *$ & 0.0026 & 0.0078 \\
\hline & $(0.0030)$ & $(0.0022)$ & $(0.0023)$ & $(0.0051)$ \\
\hline Time FE & \multicolumn{4}{|c|}{ No } \\
\hline Number of municipalities & \multicolumn{4}{|c|}{275} \\
\hline \multirow[t]{2}{*}{$\mathrm{N}$} & \multicolumn{4}{|c|}{275} \\
\hline & \multicolumn{4}{|c|}{ Panel B: Lagged share of seats } \\
\hline \multirow[t]{2}{*}{$\Delta$ Share of seats, lagged } & -0.0038 & 0.0015 & 0.0008 & $0.0058^{*}$ \\
\hline & $(0.0025)$ & $(0.0023)$ & $(0.0014)$ & $(0.0031)$ \\
\hline Time FE & \multicolumn{4}{|c|}{ Yes } \\
\hline Number of municipalities & \multicolumn{4}{|c|}{275} \\
\hline \multirow[t]{2}{*}{$\mathrm{N}$} & \multicolumn{4}{|c|}{550} \\
\hline & \multicolumn{4}{|c|}{ Panel C: Multiple lagged vote shares for anti-immigration parties } \\
\hline \multirow[t]{2}{*}{$\Delta$ Share of votes for Anti-immigration parties, lagged } & $0.0090 *$ & 0.0074 & 0.0005 & -0.0002 \\
\hline & $(0.0054)$ & $(0.0057)$ & $(0.0049)$ & $(0.0049)$ \\
\hline \multirow[t]{2}{*}{$\Delta$ Share of votes for Anti-immigration parties, lagged 2} & 0.0033 & 0.0041 & -0.0039 & -0.0033 \\
\hline & $(0.0049)$ & $(0.0050)$ & $(0.0042)$ & $(0.0042)$ \\
\hline \multirow[t]{2}{*}{$\Delta$ Share of votes for Anti-immigration parties, lagged 3} & & $0.0105^{* *}$ & & 0.0061 \\
\hline & & $(0.0048)$ & & $(0.0037)$ \\
\hline F-test of voting shares joint significance & 1.390 & 2.559 & 0.619 & 1.254 \\
\hline$\underline{\text { Prob }>F}$ & 0.251 & 0.0554 & 0.539 & 0.291 \\
\hline Conditional on lagged refugee shares & \multicolumn{2}{|c|}{ No } & \multicolumn{2}{|c|}{ Yes } \\
\hline Time FE & \multicolumn{4}{|c|}{ No } \\
\hline Number of municipalities & \multicolumn{4}{|c|}{275} \\
\hline$\underline{\mathrm{N}}$ & \multicolumn{4}{|c|}{275} \\
\hline \multicolumn{5}{|c|}{$\begin{array}{l}\text { Note: Danish municipal elections 1989-1997. Estimates are weighted by municipal population size. Share of allocated refugees is } \\
\text { calculated as the cumulative number of refugees allocated since } 1986 \text { until the year prior to election year as percent of local population } \\
\text { in 1986. Mean of the election cycle change in share of allocated refugees is } 0.13 \% \text { in Panel A and Panel C and } 0.14 \% \text { in Panel B. Panel } \\
\text { A and Panel C relate only to 1993-1997 and Panel B relates only to 1989-1997. In Panel C we condition on lagged refugee shares and } \\
\text { twice lagged refugee shares in columns (3) and (4). Heteroscedasticity robust standard errors in parentheses. } * * * \text { p }<0.01, * * \text { p }<0.05 \text {, * } \\
\text { p }<0.1 \text {. }\end{array}$} \\
\hline
\end{tabular}


Table 4a. Allocation of Refugees and Voting Behavior, Parliament Elections

(1) (2) (3)

$\Delta$ Share of votes for

\begin{tabular}{|c|c|c|c|c|}
\hline Dependent variable: & centre-left & $\begin{array}{l}\text { other (centre } \\
\text { small) }\end{array}$ & centre-right & anti-immigration \\
\hline & \multicolumn{4}{|c|}{ Panel A: Unweighted } \\
\hline \multirow[t]{3}{*}{$\Delta$ Share of allocated refugees in $\%$ of local population } & $-1.311 * * *$ & $-1.296 * *$ & $1.053^{* * *}$ & $1.554 * * *$ \\
\hline & $(0.477)$ & $(0.502)$ & $(0.393)$ & $(0.300)$ \\
\hline & \multicolumn{4}{|c|}{ Panel B: Weighted } \\
\hline \multirow[t]{3}{*}{$\Delta$ Share of allocated refugees in $\%$ of local population } & -0.702 & -0.481 & 0.451 & 0.732 \\
\hline & $(0.985)$ & $(1.375)$ & $(0.738)$ & $(0.487)$ \\
\hline & \multicolumn{4}{|c|}{ Panel C: Weighted, indicator for 5 pct. largest } \\
\hline \multirow[t]{2}{*}{$\Delta$ Share of allocated refugees in $\%$ of local population } & -1.365 & -0.799 & $0.821 * *$ & $1.343 * * *$ \\
\hline & $(0.538)$ & $(0.489)$ & $(0.386)$ & $(0.392)$ \\
\hline \multirow{2}{*}{$\begin{array}{l}\Delta \text { Share of allocated refugees in } \% \text { of local population* indicator for } \\
\text { municipality being one among the } 5 \% \text { largest }\end{array}$} & $5.124 *$ & 0.264 & -0.258 & $-5.130 * * *$ \\
\hline & $(2.794)$ & $(3.428)$ & $(1.880)$ & $(1.556)$ \\
\hline \multirow{2}{*}{$\begin{array}{l}\Delta \text { Share of allocated refugees in } \% \text { of local population for the } 5 \% \text { largst } \\
\text { municipalities (sum of the two estimates from Panel C) }\end{array}$} & 3.759 & -0.535 & 0.563 & $-3.787 * *$ \\
\hline & $(2.742)$ & $(3.393)$ & $(1.840)$ & $(1.506)$ \\
\hline Time FE & \multicolumn{4}{|c|}{ Yes } \\
\hline $\mathrm{N}$ & \multicolumn{4}{|c|}{550} \\
\hline Number of municipalities & \multicolumn{4}{|c|}{275} \\
\hline
\end{tabular}

Note: Danish Parliament elections 1990-1998. Share of allocated refugees are calculated as the total cumulative number of refugees allocated from 1986 to the year prior to the election year as percent of local population in 1986. Mean of the election cycle change in share of allocated refugees:

$0.14 \%$. Heteroscedasticity robust standard errors in parentheses. $* * * \mathrm{p}<0.01, * * \mathrm{p}<0.05, * \mathrm{p}<0.1$. 
Table 4b. Allocation of Refugees and Voting Behavior, Municipal Elections

(1)

Dependent variable:
(2)

$\Delta$ Share of votes for

other (centre small)

centre-right anti-immigration Panel A: Unweighted

\begin{tabular}{|c|c|c|c|c|}
\hline & \multicolumn{4}{|c|}{ Panel A: Unweighted } \\
\hline \multirow[t]{3}{*}{$\Delta$ Share of allocated refugees in $\%$ of local population } & -1.548 & $-3.465 * *$ & $2.407 *$ & $2.606 * * *$ \\
\hline & $(1.356)$ & $(1.690)$ & $(1.385)$ & $(0.742)$ \\
\hline & \multicolumn{4}{|c|}{ Panel B: Weighted } \\
\hline \multirow[t]{2}{*}{$\Delta$ Share of allocated refugees in $\%$ of local population } & 0.815 & $-3.767 * * *$ & 0.531 & $2.422 * * *$ \\
\hline & $(1.998)$ & $(1.274)$ & $(1.495)$ & $(0.921)$ \\
\hline
\end{tabular}

Panel C: Weighted, indicator for 5 pct. largest

$\Delta$ Share of allocated refugees in $\%$ of local population

-3.327 **

(1.486)

$-0.421$

1.433

$2.315 * * *$

$\Delta$ Share of allocated refugees in $\%$ of local population* indicator for $14.940 * * *$

(1.574)

(1.446)

(0.808) municipality being one among the $5 \%$ largest (5.239)

$\Delta$ Share of allocated refugees in $\%$ of local population for the $5 \%$ largst

$11.613 * *$

(2.899)

$-6.792 *$

$-4.044 * *$

municipalities (sum of the two estimates from Panel C)

Time FE

(5.024)

$-4.518 *$

$4.065)$

(1.913)

(2.434)

$-5.359$

$-1.729$

$\mathrm{N}$

Number of municipalities

550

275

Note: Danish municipal elections 1989-1997. Share of allocated refugees are calculated as the total cumulative number of refugees allocated from 1986 to the year prior to the election year as percent of local population in 1986. Mean of the election cycle change in share of allocated refugees:

$0.13 \%$. Heteroscedasticity robust standard errors in parentheses. $* * * \mathrm{p}<0.01, * * \mathrm{p}<0.05, * \mathrm{p}<0.1$. 
Figure 3. Allocation of Refugees and Voting for Anti-immigration Parties along the Distribution of Municipality Size
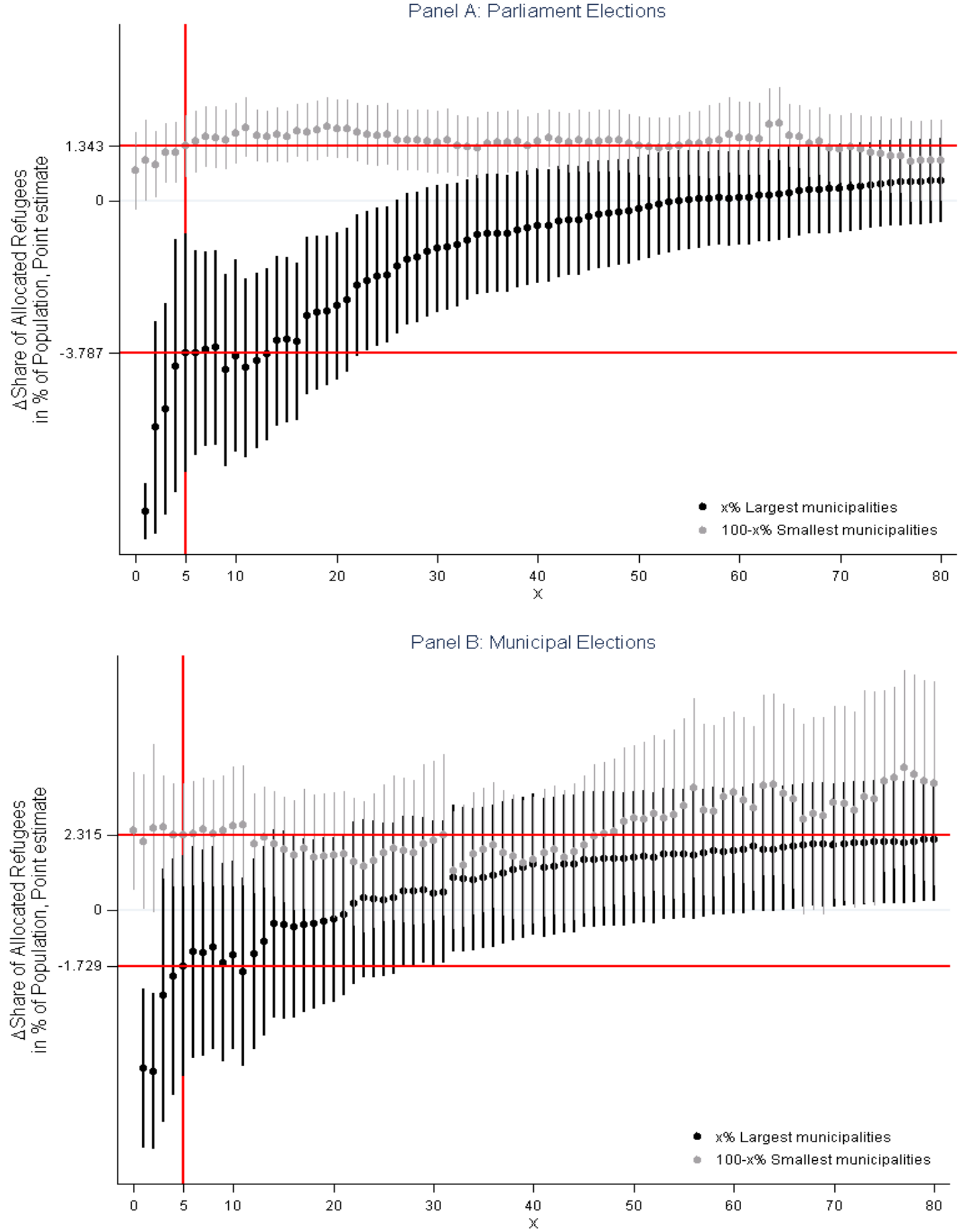

Note: Parliament elections 1990-1998 in Panel A, municipal elections 1989-1997 in Panel B. Share of allocated refugees is in percent of local population in 1986. The figures display parameter estimates of the change in the share of allocated refugees regressed on the change in share of votes for anti-immigration parties for the $100-\mathrm{x} \%$ smallest municipalities (grey dots) and for the $\mathrm{x} \%$ largest municipalities (black dots). The intersections between the horizontal lines and the vertical line corresponds to the estimates in the main regressions in Tables $4 \mathrm{a}$ and $4 \mathrm{~b}$. The vertical black and grey lines at each parameter estimate indicate the $95 \%$ confidence interval. 
Dependent variable:

$\Delta$ Share of votes for anti-immigration parties parliament elections municipal elections Panel A: Excluding Copenhagen \& Frederiksberg

\begin{tabular}{lcc}
\hline$\Delta$ Share of allocated refugees in \% of local population & $1.430^{* * *}$ & $2.349^{* * *}$ \\
& $(0.388)$ & -1.784 \\
Share of allocated refugees in \% of local population* indicator & $-4.019^{* * *}$ & $(1.821)$ \\
for municipality being one among the 5\% largest & $(1.372)$ & \\
\hline
\end{tabular}

Panel B: Conditional on share of vacant rental housing in base period

\begin{tabular}{lcc}
\hline$\Delta$ Share of allocated refugees in \% of local population & $1.091^{* * *}$ & $1.905^{* *}$ \\
& $(0.409)$ & $(0.852)$ \\
$\Delta$ Share of allocated refugees in \% of local population* indicator & $-4.841^{* * *}$ & $-3.826^{* *}$ \\
for municipality being one among the 5\% largest & $(1.350)$ & $(1.838)$ \\
\hline
\end{tabular}

for municipality being one among the $5 \%$ larges

Panel C: Conditional on change in share of vacant rental housing between election cycles

\begin{tabular}{lcc}
\hline$\Delta$ Share of allocated refugees in \% of local population & $1.246^{* * *}$ & $2.336^{* * *}$ \\
& $(0.358)$ & $(0.807)$ \\
$\Delta$ Share of allocated refugees in \% of local population* indicator & $-3.447^{* * *}$ & $-4.296^{* *}$ \\
for municipality being one among the 5\% largest & $(1.302)$ & $(2.074)$ \\
\hline
\end{tabular}
for municipality being one among the $5 \%$ larges

Panel D: Conditional on change in gross income per capita

\begin{tabular}{lcc}
\hline$\Delta$ Share of allocated refugees in \% of local population & $1.317^{* * *}$ & $2.172^{* * *}$ \\
& $(0.396)$ & $(0.800)$ \\
$\Delta$ Share of allocated refugees in \% of local population* indicator & $-4.986^{* * *}$ & $-3.914^{* *}$ \\
for municipality being one among the 5\% largest & $(1.390)$ & $(1.954)$ \\
\hline
\end{tabular}

Panel E: Conditional on change in gross income per capita and change

\begin{tabular}{lcc} 
& in share of vacant rental housing \\
\hline$\Delta$ Share of allocated refugees in \% of local population & $1.249 * * *$ & $2.193^{* * *}$ \\
& $(0.359)$ & $(0.799)$ \\
$\Delta$ Share of allocated refugees in \% of local population* indicator & $-3.460 * * *$ & $-4.154^{* *}$ \\
for municipality being one among the 5\% largest & $(1.312)$ & $(2.111)$ \\
\hline
\end{tabular}

\begin{tabular}{ll}
\hline Time FE & Yes \\
$\mathrm{N}$ & $550(546$ in Panel A) \\
Number of municipalities & 275 (273 in Panel A) \\
\hline Note: Dang Panted
\end{tabular}

Note: Danish Parliament elections 1990-1998 in (1) and Danish municipal elections 1989-1997 in (2). Share of allocated refugees are in percent of local population in 1986. Mean of the election cycle change in share of allocated refugees: $0.14 \%$ in (1) and $0.13 \%$ in (2). Estimates are weighted by municipality size in 1986 . Heteroscedasticity robust standard errors in parentheses. ${ }^{* * *} \mathrm{p}<0.01, * * \mathrm{p}<0.05$, * $\mathrm{p}<0.1$. 
Table 6 Refugees and Voting Behavior. IV Strategy

(1)

$\Delta$ Share of refugees in $\%$ of

local population size
(2)

(3)
(4)

$\Delta$ Share of votes for

Dependent variable:

centre-left

other (centre

small)

centre-right

anti-immigration

Panel A: Parliament election, weighted, indicator for $5 \%$ largest

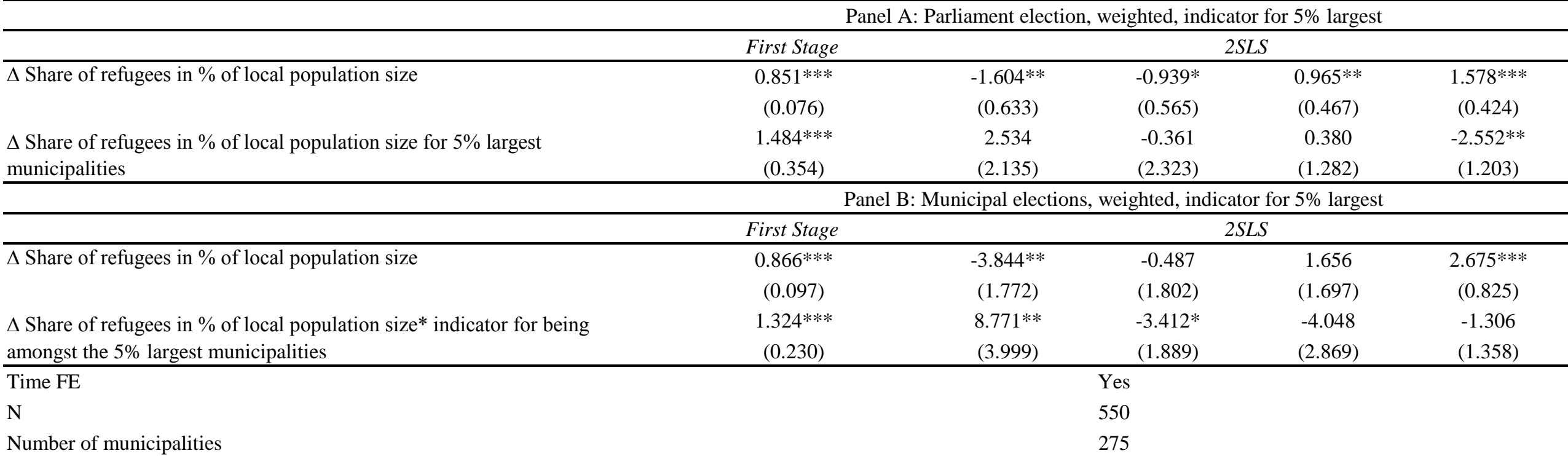

Number of municipalities

275

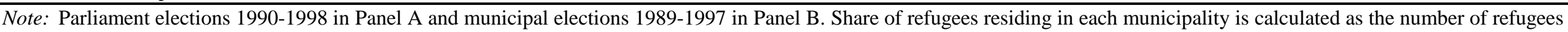
residing in the municipality the year prior to election as percent of local population in 1986. Share of allocated refugees are in percent of local population in 1986. The number of

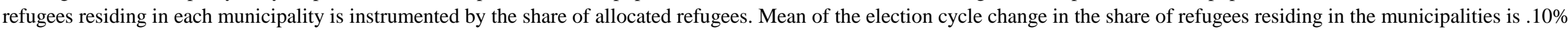
in Panel A and 0.09\% in Panel B. Mean of the election cycle change in the share of allocated refugees is $0.14 \%$ in Panel A and 0.13\% in Panel B. Column (1) shows the first stage estimates from the 2SLS estimation. Estimates are weighted by municipality size in 1986 . Heteroscedasticity robust standard errors in parentheses. $* * * \mathrm{p}<0.01, * * \mathrm{p}<0.05, * \mathrm{p}<0.1$. 
Table 7. Response to Refugee Allocation, Municipal Characteristics

\begin{tabular}{|c|c|c|c|c|c|c|}
\hline \multirow{4}{*}{ Dependent variable: } & (1) & (2) & (3) & (4) & (5) & (6) \\
\hline & \multicolumn{6}{|c|}{$\Delta$ Share of votes for Anti-immigration parties } \\
\hline & \multicolumn{3}{|c|}{ Parliament Elections } & \multicolumn{3}{|c|}{ Municipal Elections } \\
\hline & $\begin{array}{l}95 \% \text { Smallest } \\
\text { municipalities }\end{array}$ & $\begin{array}{c}5 \% \text { Largest } \\
\text { municipalities }\end{array}$ & $\begin{array}{c}5 \% \text { Largest } \\
\text { municipalities }\end{array}$ & $\begin{array}{l}\text { 95\% Smallest } \\
\text { municipalities }\end{array}$ & $\begin{array}{c}5 \% \text { Largest } \\
\text { municipalities }\end{array}$ & $\begin{array}{c}5 \% \text { Largest } \\
\text { municipalities }\end{array}$ \\
\hline & \multicolumn{6}{|c|}{ Panel A: Baseline } \\
\hline \multirow[t]{2}{*}{$\Delta$ Share of allocated refugees in $\%$ of local population } & $\begin{array}{c}1.343 * * * \\
(0.392)\end{array}$ & $\begin{array}{c}-3.787 * * \\
(1.506)\end{array}$ & $\begin{array}{c}-2.589 * * \\
(1.315)\end{array}$ & $\begin{array}{c}2.315 * * * \\
(0.808)\end{array}$ & $\begin{array}{l}-1.729 \\
(1.734)\end{array}$ & $\begin{array}{c}0.566 \\
(1.627)\end{array}$ \\
\hline & \multicolumn{6}{|c|}{ Panel B: Immigrants } \\
\hline$\Delta$ Share of allocated refugees in $\%$ of local population & $\begin{array}{c}1.332^{* * * *} \\
(0.387)\end{array}$ & $\begin{array}{c}-3.330^{* * * *} \\
(1.204)\end{array}$ & $\begin{array}{c}-2.274 \\
(1.541)\end{array}$ & $\begin{array}{c}1.966 * * * \\
(0.751)\end{array}$ & $\begin{array}{l}-0.648 \\
(1.438)\end{array}$ & $\begin{array}{c}0.211 \\
(2.398)\end{array}$ \\
\hline \multirow[t]{2}{*}{$\begin{array}{l}\Delta \text { Share of allocated refugees in } \% \text { of local population*share } \\
\text { of immigrants }\end{array}$} & $\begin{array}{c}2.305^{\text {**** }} \\
(0.417) \\
\end{array}$ & $\begin{array}{c}0.700 \\
(0.647) \\
\end{array}$ & $\begin{array}{r}-0.649 \\
(1.093) \\
\end{array}$ & $\begin{array}{c}2.626 * * * \\
(0.709) \\
\end{array}$ & $\begin{array}{l}2.255^{* *} \\
(1.057) \\
\end{array}$ & $\begin{array}{r}0.618 \\
(1.902) \\
\end{array}$ \\
\hline & \multicolumn{6}{|c|}{ Panel C: Log gross income pc } \\
\hline$\Delta$ Share of allocated refugees in $\%$ of local population & $\begin{array}{c}1.263^{* * * *} \\
(0.386)\end{array}$ & $\begin{array}{c}-4.168 * * * \\
(1.525)\end{array}$ & $\begin{array}{c}2.778^{* *} \\
(1.348)\end{array}$ & $\begin{array}{c}2.168^{* * * *} \\
(0.778)\end{array}$ & $\begin{array}{l}-2.303 \\
(1.786)\end{array}$ & $\begin{array}{c}0.215 \\
(1.628)\end{array}$ \\
\hline \multirow[t]{2}{*}{ gross income pc } & $\begin{array}{c}1.768 * * * * \\
(0.620)\end{array}$ & $\begin{array}{l}-1.224 * \\
(0.729) \\
\end{array}$ & $\begin{array}{l}-0.587 \\
(0.512)\end{array}$ & $\begin{array}{c}1.327 \\
(0.818)\end{array}$ & $\begin{array}{c}-2.400 * * * \\
(0.911)\end{array}$ & $\begin{array}{l}-1.279 \\
(0.784)\end{array}$ \\
\hline & \multicolumn{6}{|c|}{ Panel D: Share of rich } \\
\hline$\Delta$ Share of allocated refugees in $\%$ of local population & $\begin{array}{c}1.464 * * * \\
(0.413)\end{array}$ & $\begin{array}{c}-4.608 * * * \\
(1.483)\end{array}$ & $\begin{array}{c}-3.209 * * \\
(1.433)\end{array}$ & $\begin{array}{c}2.318^{* * * *} \\
(0.811)\end{array}$ & $\begin{array}{l}-3.194 \\
(2.167)\end{array}$ & $\begin{array}{c}-0.354 \\
(2.121)\end{array}$ \\
\hline \multirow{2}{*}{ of rich in in $\%$ of population } & $\begin{array}{l}1.059 * * \\
(0.438)\end{array}$ & $\begin{array}{c}-1.837 * * \\
(0.826)\end{array}$ & $\begin{array}{l}-0.960 \\
(0.707)\end{array}$ & $\begin{array}{c}0.056 \\
(0.617)\end{array}$ & $\begin{array}{c}-3.520 * * \\
(1.569)\end{array}$ & $\begin{array}{l}-1.477 \\
(1.424)\end{array}$ \\
\hline & \multicolumn{6}{|c|}{ Panel E: Crime rate } \\
\hline$\Delta$ Share of allocated refugees in $\%$ of local population & $\begin{array}{c}.205^{* * * * *} \\
(0.401)\end{array}$ & $\begin{array}{c}-3.951^{* * *} \\
(1.497)\end{array}$ & $\begin{array}{l}-1.132 \\
(2.050)\end{array}$ & $\begin{array}{c}2.230 * * * \\
(0.761)\end{array}$ & $\begin{array}{l}-2.610^{*} \\
(1.334)\end{array}$ & $\begin{array}{l}-0.746 \\
(3.956)\end{array}$ \\
\hline \multirow{2}{*}{ population*reported crime rate } & $\begin{array}{c}2.151^{* * * *} \\
(0.470)\end{array}$ & $\begin{array}{c}0.370 \\
(0.441)\end{array}$ & $\begin{array}{l}-0.785 \\
(0.699)\end{array}$ & $\begin{array}{c}2.052 * * * \\
(0.760)\end{array}$ & $\begin{array}{c}1.591 * * * \\
(0.562)\end{array}$ & $\begin{array}{c}0.696 \\
(2.160)\end{array}$ \\
\hline & \multicolumn{6}{|c|}{ Panel F: Share of Church tax payers } \\
\hline$\Delta$ Share of allocated refugees in $\%$ of local population & $\begin{array}{c}1.361^{\text {**** }} \\
(0.387)\end{array}$ & $\begin{array}{c}-3.497 * * * \\
(1.259)\end{array}$ & $\begin{array}{l}-2.605 \\
(1.625)\end{array}$ & $\begin{array}{c}2.316^{* * * *} \\
(0.819)\end{array}$ & $\begin{array}{l}-1.316 \\
(1.516)\end{array}$ & $\begin{array}{c}0.344 \\
(3.707)\end{array}$ \\
\hline \multirow[t]{2}{*}{$\begin{array}{l}\Delta \text { Share of allocated refugees in } \% \text { of local population*share } \\
\text { of church tax payers }\end{array}$} & $\begin{array}{c}-1.214 * * \\
(0.473)\end{array}$ & $\begin{array}{l}-0.970^{*} \\
(0.588)\end{array}$ & $\begin{array}{l}-0.021 \\
(0.939)\end{array}$ & $\begin{array}{l}-1.491 * \\
(0.874)\end{array}$ & $\begin{array}{l}-2.279 \\
(1.502)\end{array}$ & $\begin{array}{l}-0.272 \\
(3.233)\end{array}$ \\
\hline & \multicolumn{6}{|c|}{ Panel G: Unemployment } \\
\hline$\Delta$ Share of allocated refugees in $\%$ of local population & $\begin{array}{c}1.321 * * * * \\
(0.400)\end{array}$ & $\begin{array}{c}-6.363 * * * \\
(1.520)\end{array}$ & $\begin{array}{c}-5.186^{* * * *} \\
(1.866)\end{array}$ & $\begin{array}{c}2.369^{* * * *} \\
(0.811)\end{array}$ & $\begin{array}{c}-3.908^{* *} \\
(1.757)\end{array}$ & $\begin{array}{c}0.181 \\
(2.227)\end{array}$ \\
\hline \multirow[t]{2}{*}{$\begin{array}{l}\Delta \text { Share of allocated refugees in } \% \text { of local population*local } \\
\text { unemployment rate }\end{array}$} & $\begin{array}{c}0.152 \\
(0.329) \\
\end{array}$ & $\begin{array}{l}2.392 * * * \\
(0.696)\end{array}$ & $\begin{array}{l}1.803 * * \\
(0.913) \\
\end{array}$ & $\begin{array}{l}-0.351 \\
(0.595) \\
\end{array}$ & $\begin{array}{l}2.164^{*} \\
(1.233)\end{array}$ & $\begin{array}{c}0.283 \\
(1.639) \\
\end{array}$ \\
\hline & \multicolumn{6}{|c|}{ Panel H: Share of welfare dependent immigrants } \\
\hline$\Delta$ Share of allocated refugees in $\%$ of local population & $\begin{array}{c}.305 * * * * \\
(0.385)\end{array}$ & $\begin{array}{l}-4.321 \\
(3.499)\end{array}$ & $\begin{array}{l}-1.430 \\
(3.309)\end{array}$ & $\begin{array}{l}2.168^{* * * *} \\
(0.810)\end{array}$ & $\begin{array}{c}-7.208 \\
(5.599)\end{array}$ & $\begin{array}{l}-2.047 \\
(4.976)\end{array}$ \\
\hline \multirow[t]{2}{*}{$\begin{array}{l}\Delta \text { Share of allocated refugees in } \% \text { of local population*share } \\
\text { of welfare dependent among immigrants }\end{array}$} & $\begin{array}{c}0.623 * * \\
(0.309) \\
\end{array}$ & $\begin{array}{c}0.439 \\
(2.060)\end{array}$ & $\begin{array}{r}-0.849 \\
(1.961) \\
\end{array}$ & $\begin{array}{l}1.450 * * \\
(0.648)\end{array}$ & $\begin{array}{c}4.423 \\
(3.620) \\
\end{array}$ & $\begin{array}{c}1.898 \\
(2.992) \\
\end{array}$ \\
\hline & \multicolumn{6}{|c|}{ Panel I: Share younger than 65 with a tertiary education } \\
\hline$\Delta$ Share of allocated refugees in $\%$ of local population & $\begin{array}{c}1.363^{* * * *} \\
(0.389)\end{array}$ & $\begin{array}{l}-3.558^{* *} \\
(1.578)\end{array}$ & $\begin{array}{l}-2.315 \\
(1.434)\end{array}$ & $\begin{array}{c}2.378 * * * \\
(0.838)\end{array}$ & $\begin{array}{l}-1.510 \\
(2.554)\end{array}$ & $\begin{array}{c}0.914 \\
(2.466)\end{array}$ \\
\hline $\begin{array}{l}\Delta \text { Share of allocated refugees in } \% \text { of local population* Share } \\
\text { younger than } 65 \text { with a tertiary education }\end{array}$ & $\begin{array}{l}-0.203 \\
(0.257) \\
\end{array}$ & $\begin{array}{l}-0.355 \\
(0.512) \\
\end{array}$ & $\begin{array}{l}-0.314 \\
(0.483) \\
\end{array}$ & $\begin{array}{l}-0.477 \\
(0.712)\end{array}$ & $\begin{array}{l}-0.312 \\
(1.566)\end{array}$ & $\begin{array}{c}-0.384 \\
(1.459) \\
\end{array}$ \\
\hline Time FE & & & Yes & & & Yes \\
\hline $\mathrm{N}$ & & & 546 & & & 546 \\
\hline Municipalities & & & 273 & & & 273 \\
\hline
\end{tabular}


Table 8. Allocation of Refugees and Voter Turnout

(1) (2)

(3)

(4)

Dependent variable:

Turnout $\%$ at

parliamentary elections municipal elections

Panel A: Estimates with municipality FE

unweighted weighted unweighted weighted

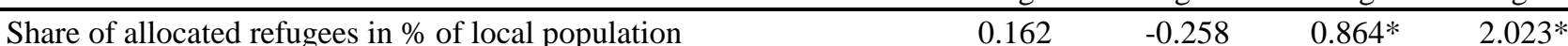

$\begin{array}{llll}(0.195) & (0.230) \quad(0.457) \quad(1.107)\end{array}$

$\mathrm{N}$

Panel B: First-difference estimates

unweighted weighted unweighted weighted

$\Delta$ Share of allocated refugees in $\%$ of local population

$-0.008$

$-0.334$

0.573

$1.493 *$

$(0.227)$

(0.301)

$(0.475)$

$(0.824)$

\begin{tabular}{ll}
\hline $\mathrm{N}$ & 550 \\
\hline Time FE & Yes
\end{tabular}

Number of municipalities

Yes

Note: Danish Parliament elections 1990-1998. Danish municipal elections 1989-1997. Share of allocated refugees are in percent of local population in 1986. Mean of the election cycle change in the share of allocated refugees: $0.14 \%$ for parliament elections, $0.13 \%$ for municipal elections. Heteroscedasticity robust standard errors in parentheses. $* * * \mathrm{p}<0.01$, $* * \mathrm{p}<0.05, * \mathrm{p}<0.1$ 
Table 9. Allocation of Refugees and Anti-immigration Parties Standing in Municipal Elections

(1)

At least one party running, both At least one party running in

Dependent variable:

$\Delta$ Share of allocated refugees periods

$0.322 * * *$

(0.088)

[0.767]

Mean of dependent variable

Time FE

Yes

550

Number of municipalities
(2)

1997

$0.412 * * *$

(0.106)

[0.807]

No

275

275

Note: Danish municipal elections 1989-1997. Share of allocated refugees are in percent of local population in 1986. Voting statistics from the Statistics Denmark Database for municipal elections. The estimates are obtained from linear probability models. Heteroscedasticity robust standard errors in parentheses. $* * * \mathrm{p}<0.01, * * \mathrm{p}<0.05, * \mathrm{p}<0.1$. 
Table 10. Attitudes Towards Immigrants and Refugees

(1) (2) (3) (5)

(7) (8)

Panel A: Attitudes towards refugees and immigrants and voting behavior Voted for an Anti-immigration party

Dependent Variable:

Opinion on amount spend on Immigrants constitute threat to Allow immigrants and refugees

Explanatory Variable:

How many more refugees can $0.1361 * * *$

Danish culture

access to social benefit

Denmark take

(0.014)

$(0.014)$

$-0.1623^{* * *}$

$-0.1544^{* * * *}$

$-0.1176^{* * * *}$

$-0.0992 * *$

$2417 * * *$

$-0.2226$

Mean of dependent variable

0.057

0.066

$(0.017)$

$(0.014)$

$(0.014)$

$(0.023)$

(0.023)

(0.233)

$(0.248)$

$(0.250)$

Panel B: Residing in a Rural area and attitudes towards refugees and immigrants

Dependent Variable:

Opinion on amount spend o

Immigrants constitute threat to

Allow immigrants and refugees

How many more refugees can

Explanatory variable: Dummy equal to 1 if the respondent is $0.0540 * * *$ Danish culture access to social benefit Denmark take

Explanatory variable: Dummy equal to 1
from one of the $5 \%$ largest municipalities

(0.013) efugee support

$0.1071 * * *$

$0.0280^{*}$

(0.019)

$0.0473^{* * *}$

$0.0654 * * *$

$0.0372 * *$

$0.0622 * * *$

$0.0330 * * *$

Mean of dependent variable

0.320

Controls

(0.316)

Election survey FE

(0.017)

(0.018)

(0.018)

(0.013)

(0.013)

Yes

(0.401)

N

4,362

Yes

No

Yes

$(0.357)$

Yes

3,597

Yes

No

Yes

(0.269)

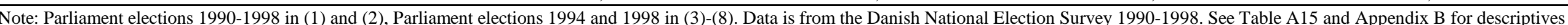

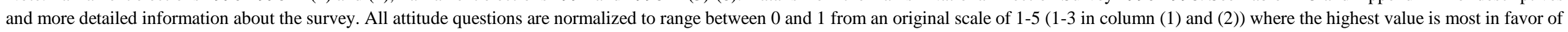
refugees and immigrants. The included controls are a gender dummy (male is reference), age group dummies (younger than 30 (reference), 30-44, 45-59 and 60+) and education dummies (No education

(reference), professional education: basic, advanced with degree, advanced short, advanced medium, advanced long). Estimates are weighted by full municipal population size divided by survey municipal

population size.Heteroscedasticity robust standard errors in parentheses. $* * * \mathrm{p}<0.01, * * \mathrm{p}<0.05,{ }^{*} \mathrm{p}<0.1$ 
Table 11. Segregation of Natives, Refugee and Non-western Immigrants Within Municipalities

\begin{tabular}{|c|c|c|c|c|c|c|}
\hline & \multicolumn{3}{|c|}{ Parliament Elections } & \multicolumn{3}{|c|}{ Municipal Elections } \\
\hline & $\begin{array}{c}\text { All } \\
\text { Municipalities }\end{array}$ & $\begin{array}{l}\text { 95\% Smallest } \\
\text { Municipalities }\end{array}$ & $\begin{array}{l}5 \% \text { Largest } \\
\text { Municipalites }\end{array}$ & $\begin{array}{c}\text { All } \\
\text { Municipalities }\end{array}$ & $\begin{array}{l}\text { 95\% Smallest } \\
\text { Municipalities }\end{array}$ & $\begin{array}{l}5 \% \text { Largest } \\
\text { Municipalites }\end{array}$ \\
\hline Interaction index, allocated refugees & -0.1548 & -0.1003 & -0.2051 & -0.1441 & -0.0913 & -0.1946 \\
\hline Interaction index, non-western immigrants & -0.1257 & -0.1088 & -0.1413 & -0.1171 & -0.1018 & -0.1313 \\
\hline$\overline{\mathrm{N}}$ & \multicolumn{6}{|c|}{810} \\
\hline
\end{tabular}

Note: Parliament elections 1990-1998, municipal elections 1989-1997. There is no neighborhood data on the municipalities on Bornholm, which is why these are left out. We

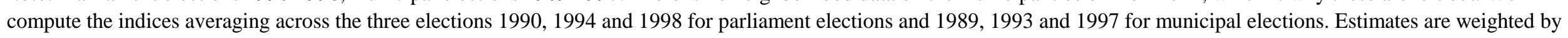
municipal population size in 1985 . The systematic interaction indices are adjusted to be measured relative to exposure under randomness. 
Table 12. Segregation of Refugees and Attitudes Towards Migration

Opinion on amount spend on Immigrants constitute threat

Allow immigrants and

\begin{tabular}{|c|c|c|c|c|c|c|c|c|c|c|}
\hline \multirow[b]{2}{*}{$\begin{array}{l}\text { Systematic interaction index, } \\
\text { allocated refugees }\end{array}$} & \multicolumn{2}{|c|}{ refugee support } & \multicolumn{2}{|c|}{ to Danish culture } & \multicolumn{2}{|c|}{ benefit } & \multicolumn{2}{|c|}{ Denmark take } & \multicolumn{2}{|c|}{ party } \\
\hline & $\begin{array}{c}-0.287 * * * \\
(0.063) \\
\end{array}$ & $\begin{array}{c}-0.194 * * * \\
(0.064) \\
\end{array}$ & $\begin{array}{c}-0.377 * * * \\
(0.087) \\
\end{array}$ & $\begin{array}{c}-0.209 * * * \\
(0.078) \\
\end{array}$ & $\begin{array}{c}-0.220 * * * \\
(0.082) \\
\end{array}$ & $\begin{array}{l}-0.122 \\
(0.083) \\
\end{array}$ & $\begin{array}{c}-0.232 * * * \\
(0.064) \\
\end{array}$ & $\begin{array}{c}-0.135^{* *} \\
(0.058) \\
\end{array}$ & $\begin{array}{c}0.057 \\
(0.054) \\
\end{array}$ & $\begin{array}{r}0.026 \\
(0.053) \\
\end{array}$ \\
\hline Individual controls & No & Yes & No & Yes & No & Yes & No & Yes & No & Yes \\
\hline Election year FE & \multicolumn{10}{|c|}{ Yes } \\
\hline $\mathrm{N}$ & \multicolumn{2}{|c|}{4,205} & \multicolumn{2}{|c|}{3,455} & \multicolumn{2}{|c|}{3,397} & \multicolumn{2}{|c|}{3,415} & \multicolumn{2}{|c|}{4,456} \\
\hline
\end{tabular}

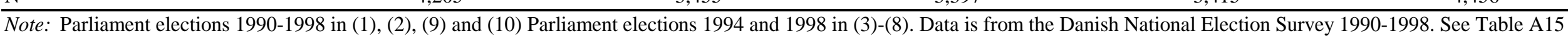

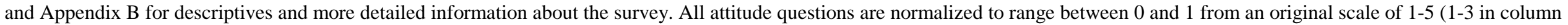
(1) and (2)) where the highest value is most in favor of refugees and immigrants. The included controls are a gender dummy (male is reference), age group dummies: younger than 30

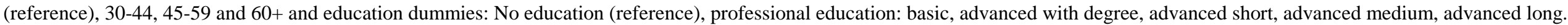
Estimates are weighted by full municipal population size divided by survey municipal population size. Heteroscedasticity robust standard errors in parentheses. $* * * \mathrm{p}<0.01, * * \mathrm{p}<0.05, *$ $\mathrm{p}<0.1$. 
Figure A1. Number of Articles in Danish National Newspapers in Which the Word "Refugee" Appears

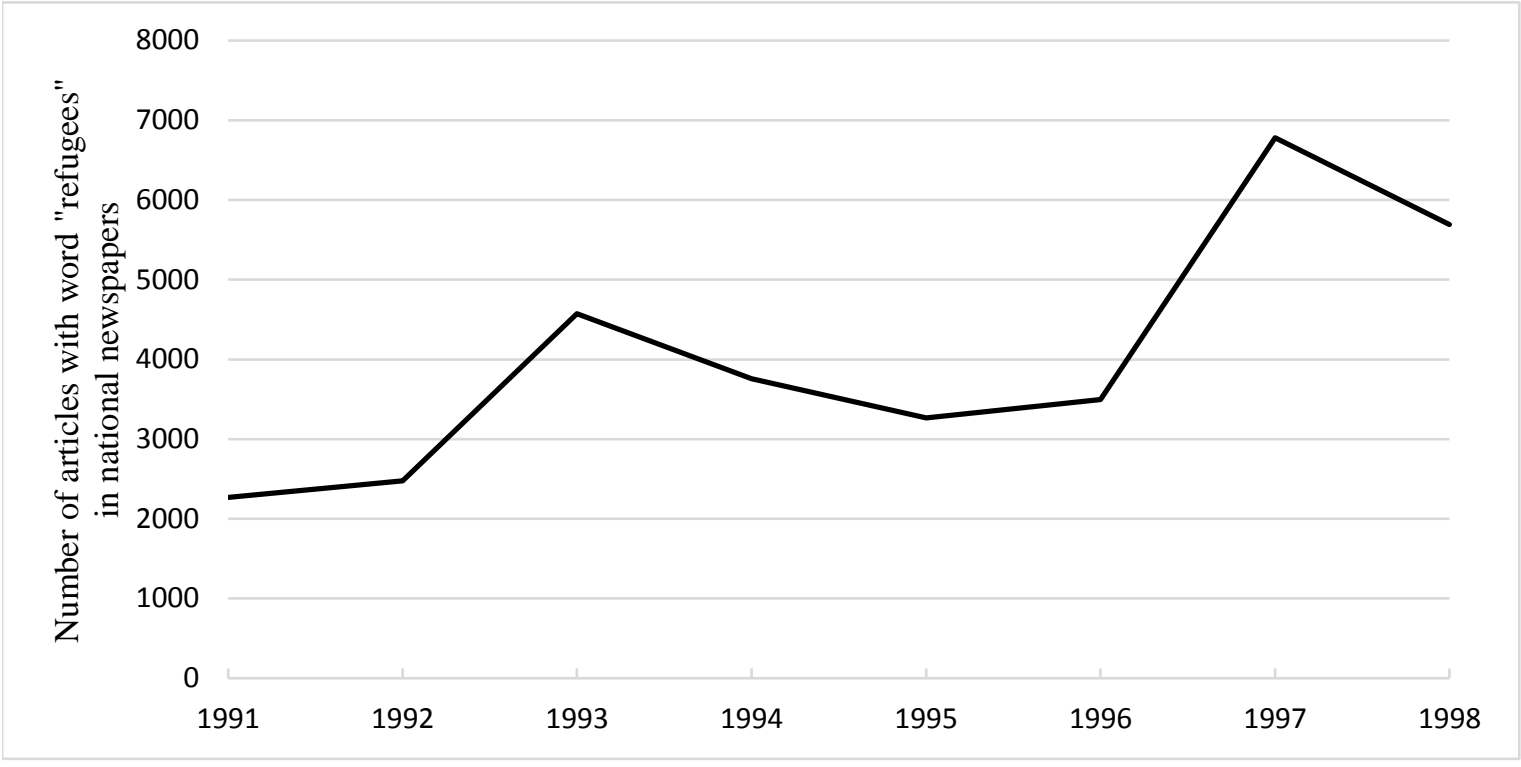

Source: Infomedia A/S.

Note: Results of search for word "Refugee" in the online archive of Danish national newspapers. 
Table A1. Summary Statistics for Voting by Year

\begin{tabular}{|c|c|c|c|c|}
\hline Variable & mean & std. dev. & $\min$ & $\max$ \\
\hline Vote share for: anti-immigration parties, \%, parliament elections 1990 & 6.45 & 2.76 & 2.96 & 20.56 \\
\hline the Progress Party, \%, parliament elections 1990 & 6.45 & 2.76 & 2.96 & 20.56 \\
\hline centre-left parties, \%, parliament elections 1990 & 53.57 & 10.51 & 23.66 & 74.55 \\
\hline centre-right parties, \%, parliament elections 1990 & 31.72 & 7.90 & 16.76 & 60.00 \\
\hline other (centre small) parties, \%, parliament elections 1990 & 8.27 & 2.27 & 3.34 & 20.48 \\
\hline Vote share for: anti-immigration parties, \%, parliament elections 1994 & 6.47 & 1.76 & 3.51 & 15.05 \\
\hline the Progress Party, \%, parliament elections 1994 & 6.47 & 1.76 & 3.51 & 15.05 \\
\hline centre-left parties, \%, parliament elections 1994 & 49.67 & 8.96 & 22.45 & 71.84 \\
\hline centre-right parties, \%, parliament elections 1994 & 38.22 & 8.22 & 20.78 & 67.15 \\
\hline other (centre small) parties, \%, parliament elections 1994 & 5.64 & 2.23 & 2.08 & 13.21 \\
\hline Vote share for: anti-immigration parties, \%, parliament elections 1998 & 9.87 & 2.39 & 6.12 & 19.23 \\
\hline the Progress Party, \%, parliament elections 1998 & 2.44 & 2.74 & 0.65 & 15.50 \\
\hline the Danish People’s Party, \%, parliament elections 1998 & 7.42 & 2.02 & 2.61 & 13.83 \\
\hline centre-left parties, \%, parliament elections 1998 & 50.34 & 8.85 & 24.29 & 69.83 \\
\hline centre-right parties, \%, parliament elections 1998 & 32.92 & 7.81 & 17.26 & 59.87 \\
\hline other (centre small) parties, \%, parliament elections 1998 & 6.87 & 1.86 & 3.70 & 18.71 \\
\hline Vote share for: anti-immigration parties, \%, municipal elections 1989 & 5.57 & 2.93 & 0.00 & 16.06 \\
\hline the Progress Party, \%, municipal elections 1989 & 5.57 & 2.93 & 0.00 & 16.06 \\
\hline centre-left parties, \%, municipal elections 1989 & 50.85 & 13.63 & 12.60 & 79.88 \\
\hline centre-right parties, \%, municipal elections 1989 & 32.14 & 11.76 & 0.00 & 65.26 \\
\hline other (centre small) parties, \%, municipal elections 1989 & 11.43 & 9.62 & 0.00 & 84.70 \\
\hline Vote share for: anti-immigration parties, \%, municipal elections 1993 & 4.38 & 2.81 & 0.00 & 17.49 \\
\hline the Progress Party, \%, municipal elections 199 & 4.38 & 2.81 & 0.00 & 17.49 \\
\hline centre-left parties, \%, municipal elections 1993 & 47.49 & 12.82 & 13.08 & 79.73 \\
\hline centre-right parties, \%, municipal elections 1993 & 38.30 & 11.81 & 0.00 & 73.72 \\
\hline other (centre small) parties, \%, municipal elections 1993 & 9.83 & 9.43 & 0.00 & 85.35 \\
\hline Vote share for: anti-immigration parties, \%, municipal elections 1997 & 6.78 & 3.64 & 0.00 & 17.09 \\
\hline the Progress Party, \%, municipal elections 1997 & 1.59 & 2.18 & 0.00 & 17.09 \\
\hline the Danish People's Party, \%, municipal elections 1997 & 5.19 & 3.77 & 0.00 & 15.43 \\
\hline centre-left parties, \%, municipal elections 1997 & 46.75 & 12.52 & 9.11 & 74.38 \\
\hline centre-right parties, \%, municipal elections 1997 & 36.47 & 12.32 & 0.00 & 74.50 \\
\hline other (centre small) parties, \%, municipal elections 1997 & 10.00 & 10.15 & 0.00 & 84.97 \\
\hline
\end{tabular}

Note: Voting statistics from the Danish Ministry of the Interior for parliament elections and Statistics Denmark Database for municipal elections. 275 Danish municipalities. Parliament elections: 1990, 1994, 1998. Municipal elections: 1989, 1993, 1997. Statistics are weighted by municipal population size in 1986. Please see Table A4 for the detailed description of data construction. 
Figure A2. Refugee Allocation and Voting Behavior
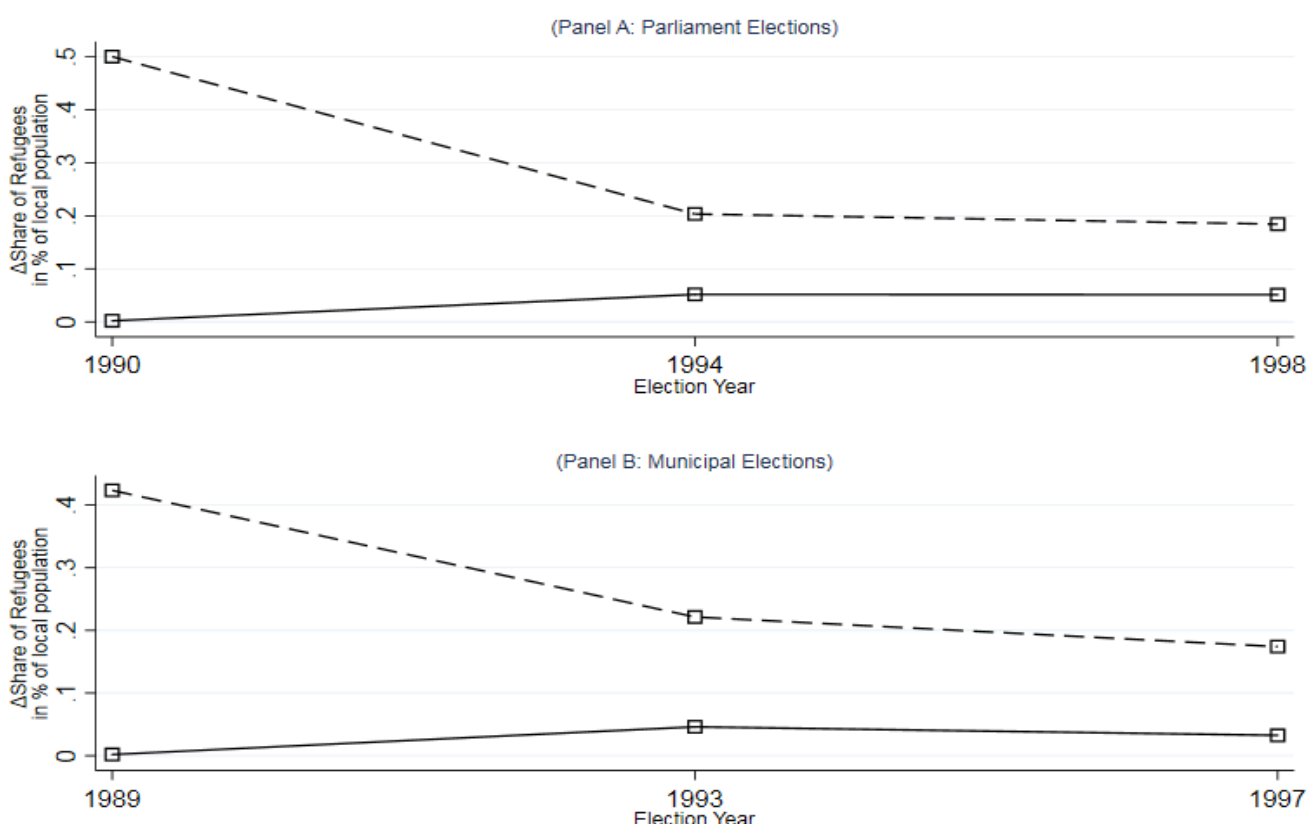

Note: Parliament elections 1985-1998 in Panel A and municipal elections 1985-1997 in Panel B. Share of allocated refugees in percent of local population in 1986. The figure displays the change in share of allocated refugees for the $20 \%$ municipalities receiving the smallest refugee share (solid lines) and for the $40 \%$ municipalities receiving the largest refugee share (dashed lines) during the first election cycle. 
Figure A3. Allocated Refugees as Percent of Danish population, 1986

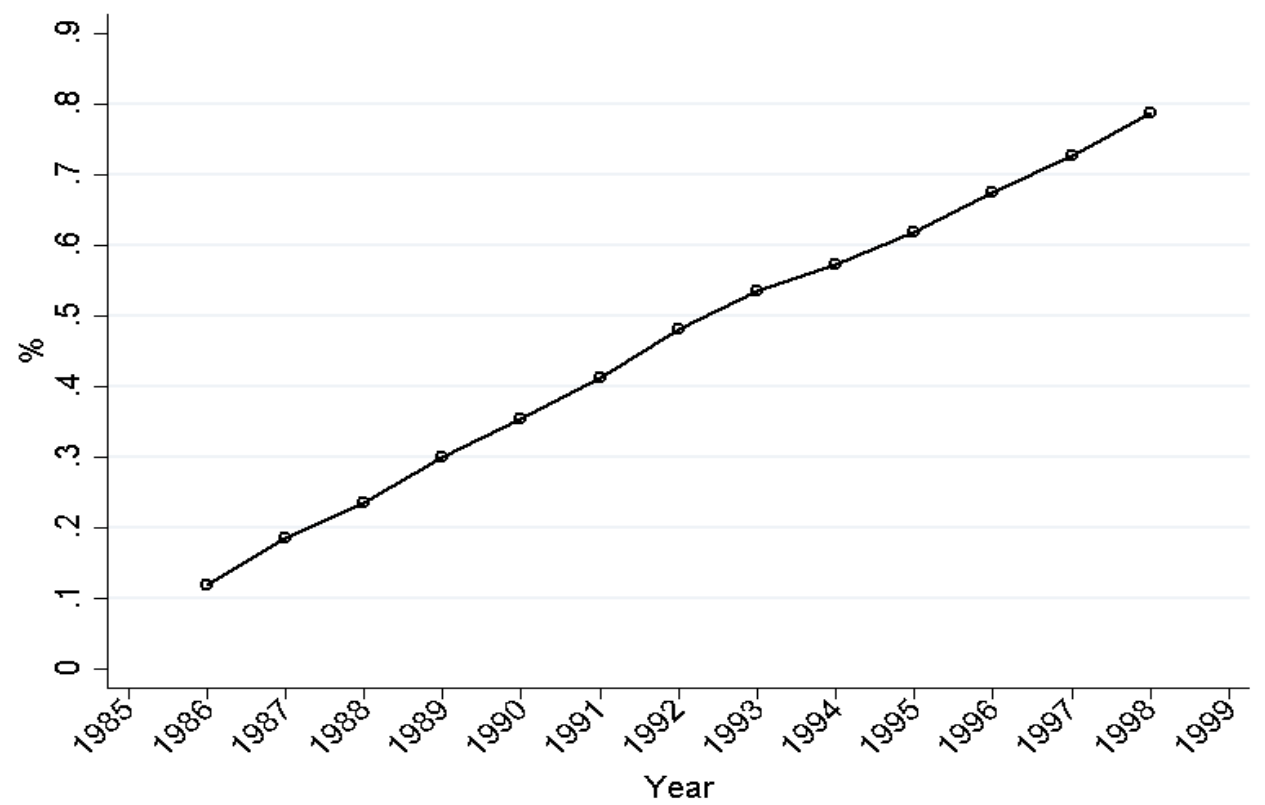

Source: Own calculations based on Statistics Denmark register data.

Note: Vertical axis: Allocated refugees since 1986 in percent of local population size in 1986. Horizontal axis: year. 
Table A2. Correlation Between Allocation of Balkan Refugees and Other Refugees

(1) (2)

$\Delta$ Share of allocated refugees in $\%$ of local population

\begin{tabular}{|c|c|c|}
\hline$\Delta$ Share of Balkan refugees in $\%$ of local population & $\begin{array}{l}-0.012 \\
(0.014) \\
\end{array}$ & $\begin{array}{r}-0.013 \\
(0.015) \\
\end{array}$ \\
\hline Time FE & No & Yes \\
\hline Number of municipalities & & \\
\hline Observations & & \\
\hline
\end{tabular}

Note: Parliament elections 1990-1998. Heteroscedasticity robust standard errors in parentheses. *** $\mathrm{p}<0.01, * * \mathrm{p}<0.05, * \mathrm{p}<0.1$. 
Table A3. Variation in Refugees Assigned to Danish Municipalities, 1986-1998

\begin{tabular}{lccccc}
\hline & mean & standard deviation & between & within & $\mathrm{N}$ \\
\hline Share of allocated refugees & $0.38 \%$ & $0.40 \%$ & $0.36 \%$ & $0.17 \%$ & 825 \\
Change in share of allocated refugees & $0.14 \%$ & $0.18 \%$ & $0.15 \%$ & $0.11 \%$ & 550 \\
\hline
\end{tabular}

Note: "Share of allocated refugees" is calculated as the total cumulative number of refugees allocated from 1986 until the year prior to the election year as a percent of local population in 1986. 
The Danish Ministry of the Interior, can be downloaded at www.oim.dk

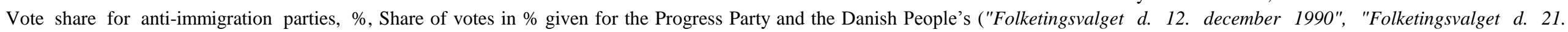
parliament (municipal) elections Party at parliament (municipal) elections september 1994" and "Folketingsvalget d. 11. marts 1998"), Statistics Denmark Database, table VALG2 and VALGK3X

The Danish Ministry of the Interior, can be downloaded at www.oim.dk

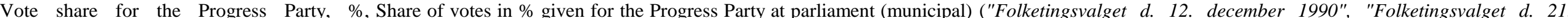
parliament (municipal) elections elections september 1994" and "Folketingsvalget d. 11. marts 1998"), Statistics Denmark Database, table VALG2 and VALGK3X

The Danish Ministry of the Interior, can be downloaded at www.oim.dk

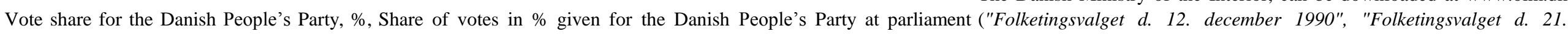
parliament (municipal) elections (municipal) elections september 1994" and "Folketingsvalget d. 11. marts 1998"), Statistics Denmark Database, table VALG2 and VALGK3X

Share of votes in $\%$ given for the Social Democrats, the Danish Social The Danish Ministry of the Interior, can be downloaded at www.oim.dk ("Folketingsvalget d. 12. december 1990", "Folketingsvalget d. 21 parliament (municipal) election
Green Party, the Common Cour parliament (municipal) elections Denmark Database, table VALG2 and VALGK3X

Vote share for centre-right parties, \%, Share of votes in \% given for the Conservative People's Party and the parliament (municipal) elections Denmark's Liberal Party at parliament (municipal) elections

The Danish Ministry of the Interior, can be downloaded at www.oim.dk september 1994" and "Folketingsvalget d. 11. marts 1998"), Statistics Denmark Database, table VALG2 and VALGK3X

Share of votes in \% given for the Centre Democratic Party, the Christian The Danish Ministry of the Interior, can be downloaded at www.oim.dk Vote share for other (centre small) parties, \%, Share of votes in \% given for the Centre Democratic Party, the Christian parliament (municipal) elections

("Folketingsvalget d. 12. december 1990", "Folketingsvalget d. 21. the Human . (municipal) elections Denmark Database, table VALG2 and VALGK3X

Turnout for parliament (municipal) elections,
Turnout in $\%$ of all potential voters at parliament (municipal) elections
Turnout statistics from the Danish Ministry of the Interior for parliament elections. Turnout statistics from the "Municipal elections in municipalities and counties on the 21st of November, 1989" statistical book and Statistics Denmark Statistical Yearbooks for municipal elections. 
Change between elections in the cumulative number of refugees

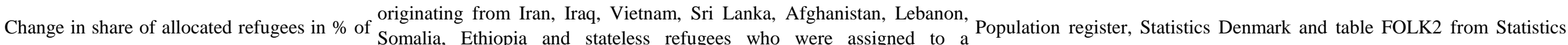
local population municipality from 1986 till the year prior to elections divided by the Denmark Database population size of that municipality on January $1^{\text {st }} 1986$.

\begin{tabular}{|c|c|c|}
\hline \multicolumn{3}{|c|}{ Panel C: Municipal characteristics, 1985} \\
\hline Population & Population per 01.01 .1986 & Statistics Denmark Database, table BEV1 \\
\hline Share of rich in local population, $\%$ & $\begin{array}{l}\text { The share }(\%) \text { of adults whose disposable income per household member } \\
\text { is } 50 \% \text { above Danish median }\end{array}$ & Population, Income and Educational registers, Statistics Denmark \\
\hline Mean log gross income per capita & $\begin{array}{l}\text { Log of total gross income (in } 1000 \mathrm{DKK} \text { ) in a municipality divided by the } \\
\text { municipality population size (only those liable to pay income tax are } \\
\text { observed) }\end{array}$ & Statistics Denmark Database, table IF212 and table BEV1 \\
\hline Mean age & Average age of municipal population & Population register, Statistics Denmark \\
\hline Local unemployment rate, $\%$, November & $\begin{array}{l}\text { The share of unemployed as } \% \text { of those who are in the labour force in } \\
\text { November }\end{array}$ & Labour force and Socioeconomic registers, Statistics Denmark \\
\hline $\begin{array}{l}\text { Share of immigrants (1st and 2nd generation), } \\
\%\end{array}$ & $\begin{array}{l}\text { Share of individuals born abroad or in Denmark for whom neither of } \\
\text { parents is born in Denmark and has Danish citizenship }\end{array}$ & Population register, Statistics Denmark \\
\hline Reported crime rate, $\%$ & Number of reported crimes divided by population size, $\%$ & $\begin{array}{l}\text { "Statistiske Efterretninger om Social Sikring og Retsvæsen", Statistics } \\
\text { Denmark and Statistics Denmark Database, table BEV1 }\end{array}$ \\
\hline $\begin{array}{l}\text { Share of native population paying voluntary } \\
\text { church tax, } \%\end{array}$ & $\begin{array}{l}\text { Share of adults who payed church tax divided by the total number of adults } \\
\text { paying income tax }\end{array}$ & Population and Income registers, Statistics Denmark \\
\hline $\begin{array}{l}\text { Share of welfare dependent among } \\
\text { immigrants, } \%\end{array}$ & $\begin{array}{l}\text { Number of immigrants who are not employed divided by the total number } \\
\text { of immigrants aged } 18-64\end{array}$ & Populations and Socioeconomic registers, Statistics Denmark \\
\hline $\begin{array}{l}\text { Share with a tertiary education among those } \\
\text { younger than } 65\end{array}$ & $\begin{array}{l}\text { Share in the municipal population younger than } 65 \text { who have completed a } \\
\text { tertiary education }\end{array}$ & Population and Educational register, Statistics Denmark \\
\hline Share of vacant rental housing & $\begin{array}{l}\text { The share of residential rental housing in the municipality that does not } \\
\text { have anyone registered as living there. }\end{array}$ & Residential register and Population register, Statistics Denmark \\
\hline
\end{tabular}


Table A5. Characteristics of Allocated Refugees

\begin{tabular}{|c|c|c|c|c|c|c|c|c|c|}
\hline $\begin{array}{l}\text { Number of } \\
\text { allocated refugees }\end{array}$ & $\begin{array}{l}\text { Mean year of } \\
\text { immigration }\end{array}$ & $\begin{array}{l}\text { Arrive with family } \\
\qquad(\%)\end{array}$ & Men (\%) & Mean age & $\begin{array}{l}\text { Share with at least } \\
\text { professional } \\
\text { qualification }(\%)\end{array}$ & $\begin{array}{l}\text { Welfare } \\
\text { dependent, 2nd } \\
\text { year since } \\
\text { immigration }(\%)\end{array}$ & $\begin{array}{c}\text { Unemployment } \\
\text { rate, 2nd year } \\
\text { since immigration } \\
(\%)\end{array}$ & $\begin{array}{l}\text { Welfare } \\
\text { dependent, 10th } \\
\text { year since } \\
\text { immigration }(\%)\end{array}$ & $\begin{array}{c}\text { Unemployment } \\
\text { rate, 10th year } \\
\text { since immigration } \\
(\%)\end{array}$ \\
\hline 40,283 & 1991 & 51 & 61 & 25.3 & 24.8 & 96.3 & 84.8 & 67.8 & 60.5 \\
\hline
\end{tabular}

Source: Own calculations based on Statistics Denmark register data.

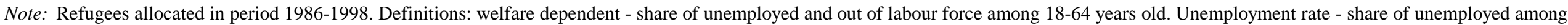
those in labour force among 18-64 years old. Share with at least professional qualification - share of adults holding at least a professional qualification. 
Table A6. Balancing Turnout

(1)

Panel A: $\Delta$ Share of allocated refugees in $\%$ of local population, 4 years after municipal elections parliament elections

\begin{tabular}{|c|c|c|}
\hline$\overline{\Delta \text { Turnout, lagged }}$ & $\begin{array}{c}0.0059 \\
(0.0053) \\
\end{array}$ & $\begin{array}{c}0.0079 \\
(0.0132) \\
\end{array}$ \\
\hline Conditional on lagged refugee shares & & Yes \\
\hline & Panel B: $\Delta$ Share of allocated re & $\begin{array}{l}\% \text { of local population, } 4 \text { years after parliament } \\
\text { lections }\end{array}$ \\
\hline$\Delta$ Turnout, lagged & $\begin{array}{l}-0.0079 \\
(0.0147)\end{array}$ & $\begin{array}{c}0.0049 \\
(0.0124)\end{array}$ \\
\hline$\Delta$ Turnout, lagged 2 & $\begin{array}{c}-0.0468^{* * *} \\
(0.0158)\end{array}$ & $\begin{array}{l}-0.0156 \\
(0.0156)\end{array}$ \\
\hline$\Delta$ Turnout, lagged 3 & $\begin{array}{c}-0.0501 * * * \\
(0.0169) \\
\end{array}$ & $\begin{array}{l}-0.0121 \\
(0.0152) \\
\end{array}$ \\
\hline Joint significance of turnout estimates & 5.201 & 0.462 \\
\hline Prob $>F$ & 0.00166 & 0.709 \\
\hline Conditional on lagged refugee shares & No & Yes \\
\hline Time FE & & No \\
\hline Number of municipalities & & 275 \\
\hline $\mathrm{N}$ & & 275 \\
\hline
\end{tabular}

Note: Danish municipal elections 1989-1993 and Parliament election 1990-1994 in panel A. Danish Parliament elections 1987-1994 in panel B. Estimates are weighted by municipal population size. Share of allocated refugees are in percent of local population in 1986. Heteroscedasticity robust standard errors in parentheses. $* * * \mathrm{p}<0.01, * * \mathrm{p}<0.05, * \mathrm{p}<0.1$. 
Dependent variable:

$\Delta$ Share of votes for Anti-Immigration parties at Parliament Elections Municipal Elections

\begin{tabular}{lcc}
\hline & \multicolumn{2}{c}{ Panel A: Weighted } \\
\hline$\Delta$ Share of allocated refugees in \% of local population & $1.7518^{* * *}$ & $4.6716^{* * *}$ \\
Share of allocated refugees in \% of local population & $(0.5755)$ & $-1.4988)$ \\
& -0.5682 & $(0.8424)$ \\
\hline & $(0.3785)$ & Panel B: Weighted, indicator for 5\% largest \\
\hline$\Delta$ Share of allocated refugees in \% of local population & $1.4860^{* * *}$ & $3.6929 * * *$ \\
& $(0.5447)$ & $(1.2876)$ \\
$\Delta$ Share of allocated refugees in \% of local population* indicator for & -3.3485 & 2.4113 \\
being amongst the 5\% largest municipalities & $(2.6296)$ & $(5.7587)$ \\
Share of allocated refugees in \% of local population & -0.0958 & -0.9381 \\
& $(0.2518)$ & $(0.6064)$ \\
Share of allocated refugees in \% of local population* indicator for & -0.7192 & -2.9348 \\
being amongst the 5\% largest municipalities & $(1.1071)$ & $(3.0874)$ \\
\hline F: F-test of joint significance of level variable & 0.358 & 2.015 \\
Prob $>$ F & 0.699 & 0.134 \\
\hline Time FE & & Yes \\
N & & 550 \\
Number of municipalities & & 275 \\
\hline N
\end{tabular}

Note: Danish Parliament elections 1990-1998 and Danish municipal elections 1989-1997. Share of allocated refugees are in percent of local population in 1986. Mean of the election cycle change in share of allocated refugees: $0.14 \%$ in column (1) and $0.13 \%$ in column (2). The F-test in panel B tests the joint significance of the "share of allocated refugees" and the "share of allocated refugees" interacted with a dummy indicating if the municipality is amongst the $5 \%$ largest. Heteroscedasticity robust standard errors in parentheses. $* * * \mathrm{p}<0.01, * * \mathrm{p}<0.05, * \mathrm{p}<0.1$. 

(1)

(7)

$\Delta$ Share of refugees allocated to the municipalities 4 years after election with highest completed education being

Dependent variable:

Upper Secondary o

Primary School

Upper Secondary

Qualifying Education

Tertiary Education

Missing Education

Municipality Received 0 Refugees $(0 / 1)$

\begin{tabular}{|c|c|c|c|c|c|c|c|}
\hline \multirow{4}{*}{$\begin{array}{l}\Delta \text { Share of votes for anti-immigration } \\
\text { parties, lagged }\end{array}$} & \multirow{2}{*}{\multicolumn{7}{|c|}{ Panel A: Change in share of votes for anti-immigration parties }} \\
\hline & & & & & & & \\
\hline & -0.0002 & -0.0015 & 0.0013 & -0.0006 & 0.0022 & -0.0014 & -0.0114 \\
\hline & $(0.0035)$ & $(0.0028)$ & $(0.0018)$ & $(0.0024)$ & $(0.0025)$ & $(0.0059)$ & $(0.0069)$ \\
\hline Mean of dependent variable & {$[0.2052]$} & [0.1403] & [0.0649] & {$[0.0837]$} & {$[0.1082]$} & [0.6028] & [0.2945] \\
\hline Time FE & \multicolumn{6}{|c|}{ No } & No \\
\hline Number of municipalities & \multicolumn{6}{|c|}{194} & 275 \\
\hline \multirow[t]{2}{*}{$\mathrm{N}$} & \multicolumn{6}{|c|}{194} & 275 \\
\hline & \multicolumn{7}{|c|}{ Panel B: Change in the share of seats for anti-immigration parties } \\
\hline \multirow{3}{*}{$\begin{array}{l}\text { Share of seats for anti-immigration } \\
\text { parties, lagged } \\
\text { Mean of dependent variable }\end{array}$} & 0.0015 & 0.0009 & 0.0006 & -0.0003 & -0.0003 & -0.0009 & -0.0064 \\
\hline & $(0.0018)$ & $(0.0016)$ & $(0.0010)$ & $(0.0014)$ & $(0.0015)$ & $(0.0029)$ & $(0.0041)$ \\
\hline & {$[0.1783]$} & {$[0.1201]$} & {$[0.0582]$} & {$[0.0886]$} & {$[0.1027]$} & [0.6304] & [0.2964] \\
\hline Time FE & \multicolumn{6}{|c|}{ Yes } & Yes \\
\hline Number of municipalities & \multicolumn{6}{|c|}{222} & 275 \\
\hline $\mathrm{N}$ & \multicolumn{6}{|c|}{387} & 550 \\
\hline
\end{tabular}

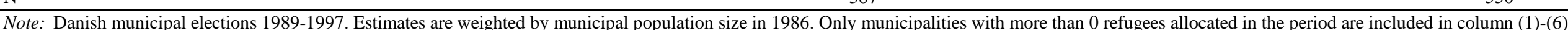

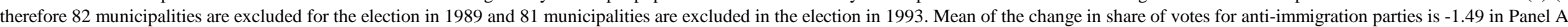

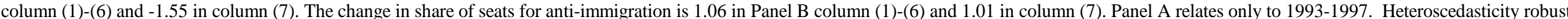
standard errors in parentheses. $* * * p<0.01, * * p<0.05, * p<0.1$. 
(1)

Explanatory variable:
$\Delta$ Share of votes for
(2)

$\Delta$ Share of seats for

Dependent variable: anti-immigration parties

$\Delta$ Share of allocated refugees in $\%$ of local population, 4 years after election

0.0078

$(0.0051)$

0.0031

(0.0032)

$0.0047^{*}$

(0.0027)

$-0.0000$

(0.0007)

$\Delta$ Share of allocated refugees from Asia in $\%$ of local population, 4 years after election

$\%$ of local population, 4 years after election

275

275

Number of municipalities 275

$0.0058^{*}$

$(0.0031)$

0.0016

(0.0019)

0.0023

$(0.0016)$

$0.0020 * *$ $(0.0010)$

Yes

Note: Danish municipal elections 1989-1997. Estimates are weighted by municipal population size in 1986. Mean in the change of the share of allocated refugees is $0.13 \%$ in column (1) and $0.14 \%$ in column (2). From the Middle east: $0.07 \%$ in (1) and 0.08 in (2), from Africa: $0.05 \%$ in (1) and $0.03 \%$ in (2), from Asia: $0.02 \%$ in (1) and $0.03 \%$ in (2). Middleeastern countries: Iraq, Iran, Lebanon \& Afghanistan. African countries: Ethiopia \& Somalia. Asian countries: Vietnam \& Sri Lanka. Specification (2) relates only to the 1993-1997 election cycle. Heteroscedasticity robust standard errors in parentheses. $* * * \mathrm{p}<0.01, * * \mathrm{p}<0.05, * \mathrm{p}<0.1$. 
Table A10. Balancing Test, Pre Allocation Municipal Characteristics \& Refugee Allocation

Dependent vaiable:

$\Delta$ Share of allocated refugees in \% of local population from 1986-1998 for

Share of rich in $\%$ of local population smaller, rural municipalities larger, urban municipalities

larger, urban municipalities

\begin{tabular}{cccccc}
-0.0041 & 0.0026 & -0.0193 & -0.0315 & $-0.0423 * * *$ & -0.0109 \\
$(0.0043)$ & $(0.0046)$ & $(0.0218)$ & $(0.0222)$ & $(0.0122)$ & $(0.0160)$ \\
-0.0089 & 0.0143 & $-0.2002^{* *}$ & $-0.2634 * *$ & $-0.2176^{* * *}$ & -0.0797 \\
$(0.0247)$ & $(0.0258)$ & $(0.0840)$ & $(0.1012)$ & $(0.0635)$ & $(0.0519)$ \\
-0.0007 & -0.0205 & $-0.1021^{* * *}$ & $-0.1413 * * *$ & -0.1252 & -0.0139 \\
$(0.0149)$ & $(0.0168)$ & $(0.0262)$ & $(0.0344)$ & $(0.0792)$ & $(0.0755)$ \\
-0.0025 & 0.0012 & -0.0674 & $-0.1952 * *$ & $0.2107 * *$ & 0.1011 \\
$(0.0290)$ & $(0.0299)$ & $(0.0383)$ & $(0.0796)$ & $(0.0843)$ & $(0.0995)$ \\
-0.0018 & 0.0164 & $0.0631^{* * *}$ & $0.1041 * * *$ & 0.0747 & 0.0275 \\
$(0.0106)$ & $(0.0116)$ & $(0.0152)$ & $(0.0215)$ & $(0.0712)$ & $(0.0399)$ \\
$0.0640 * *$ & -0.0163 & 0.1355 & $0.4508 * *$ & $0.3207 * * *$ & 0.1432 \\
$(0.0303)$ & $(0.0262)$ & $(0.1398)$ & $(0.1867)$ & $(0.0941)$ & $(0.1004)$ \\
0.0056 & -0.0058 & 0.0403 & 0.0725 & $0.0776 * * *$ & 0.0239 \\
$(0.0041)$ & $(0.0043)$ & $(0.0430)$ & $(0.0560)$ & $(0.0177)$ & $(0.0245)$ \\
0.5479 & 0.5729 & $-4.5202 *$ & -4.6385 & -3.3867 & -0.9888 \\
$(0.9230)$ & $(0.8749)$ & $(2.3648)$ & $(2.6997)$ & $(2.5815)$ & $(1.9850)$ \\
\hline No & Yes & No & Yes & No & Yes \\
262 & 262 & 13 & 13 & 11 & 11 \\
\hline
\end{tabular}

Con vacant rental houses in 1985

Note: Number of allocated refugees is calculated as the total cumulative number of allocated refugees from 1986-1998 as a percent of local population in 1986. Estimates are weighted with municipal population size in 1986. The predictors that are standardized are so with mean 0 and standard deviation 1. In (1) and (2) the 5\% largest municipalities are excluded, in (3) and (4) the 95\% smallest municipalities are excluded, in (5) and (6) Copenhagen, Frederiksberg \& the 95\% smallest municipalities are excluded. We condition on the share of all rental housing that are vacant in 1985. These are calculated as the share of rental houses that does not have anyone registered as living there when merging together the population and housing registers. Heteroscedasticity robust standard errors in parentheses. $* * * \mathrm{p}<0.01, * * \mathrm{p}<0.05, * \mathrm{p}<0.1$. 
Table A11a. Allocation of Refugees and Voting Behavior, Parliament Elections, Robustness Checks

(1)

Dependent variable:
(2)

$\Delta$ Share of votes for

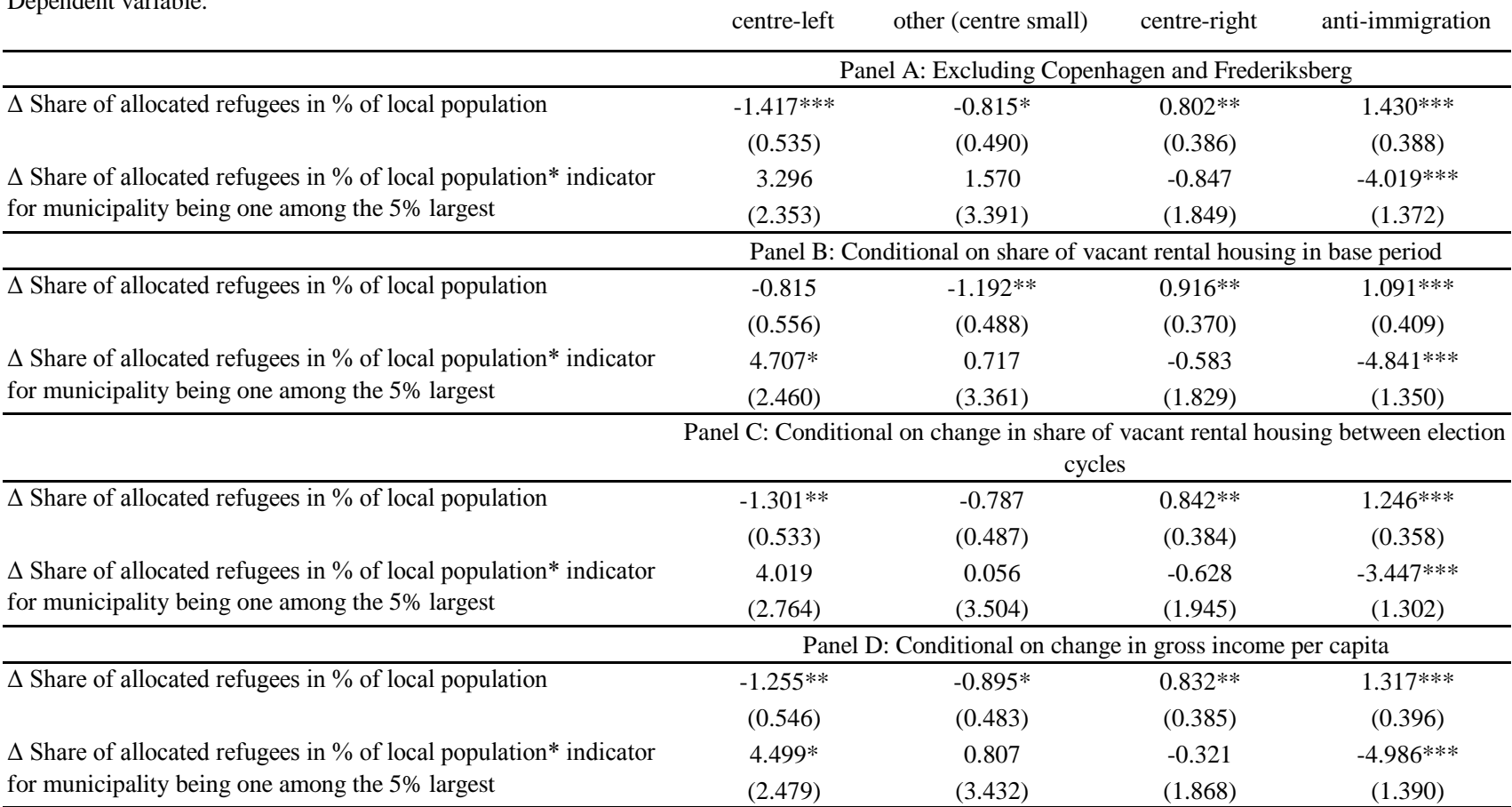

Panel E: Conditional on change in gross income per capita \& change in share of

\begin{tabular}{|c|c|c|c|c|}
\hline \multirow{2}{*}{$\Delta$ Share of allocated refugees in $\%$ of local population } & \multicolumn{4}{|c|}{ vacant rental housing } \\
\hline & $-1.216^{* *}$ & $-0.880 *$ & $0.847 * *$ & $1.249 * * *$ \\
\hline & $(0.536)$ & $(0.482)$ & $(0.384)$ & $(0.359)$ \\
\hline \multirow{2}{*}{$\begin{array}{l}\Delta \text { Share of allocated refugees in } \% \text { of local population* indicator } \\
\text { for municipality being one among the } 5 \% \text { largest }\end{array}$} & 3.630 & 0.479 & -0.649 & $-3.460 * * *$ \\
\hline & $(2.682)$ & $(3.492)$ & $(1.924)$ & $(1.312)$ \\
\hline Time FE & \multicolumn{4}{|c|}{ Yes } \\
\hline $\mathrm{N}$ & \multicolumn{4}{|c|}{550 (546 in Panel A) } \\
\hline Number of municipalities & \multicolumn{4}{|c|}{275 (273 in Panel A) } \\
\hline
\end{tabular}


Table A11b. Allocation of Refugees and Voting Behavior, Municipal Elections, Robustness Checks

Dependent variable:

$\Delta$ Share of votes for

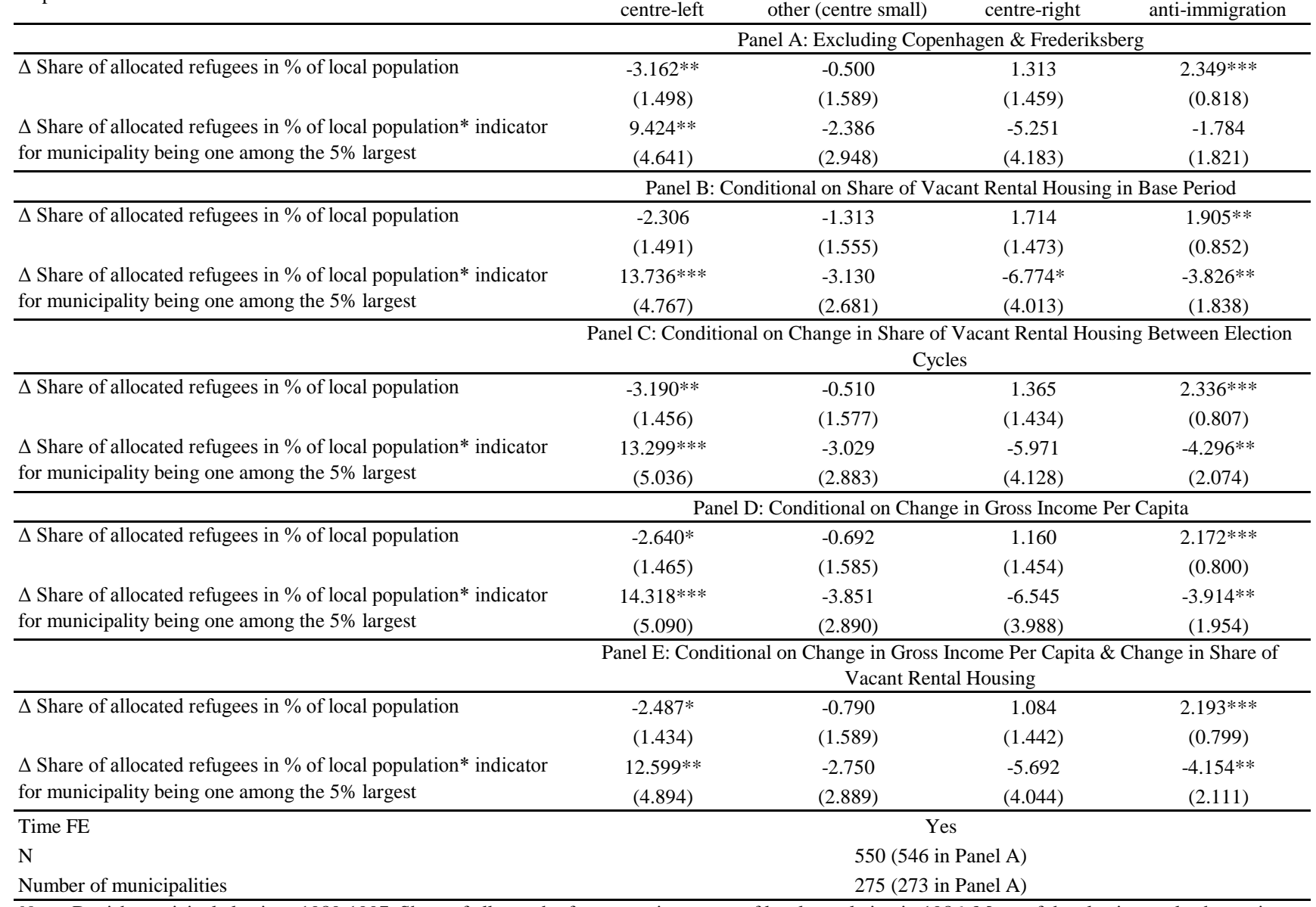

Note: Danish municipal elections 1989-1997. Share of allocated refugees are in percent of local population in 1986. Mean of the election cycle change in share of allocated refugees: $0.13 \%$. Estimates are weighted by municipal population size in 1986 . Heteroscedasticity robust standard errors in parentheses. $* * * \mathrm{p}<0.01, * * \mathrm{p}<0.05, * \mathrm{p}<0.1$ 
Table A12a. Response to Refugee Allocation, Municipal Characteristics, Parliament Elections

\begin{tabular}{|c|c|c|c|c|c|c|}
\hline \multirow{3}{*}{ Dependent variable: } & (1) & $(2)$ & (3) & (4) & $(5)$ & (6) \\
\hline & \multicolumn{6}{|c|}{$\begin{array}{l}\Delta \text { Share of votes for } \\
\text { other (centre small) }\end{array}$} \\
\hline & $\begin{array}{l}\text { 95\% Smallest } \\
\text { municipalities }\end{array}$ & $\begin{array}{l}5 \% \text { Largest } \\
\text { municipalities }\end{array}$ & $\begin{array}{l}\text { 95\% Smallest } \\
\text { municipalities }\end{array}$ & $\begin{array}{c}5 \% \text { Largest } \\
\text { municipalities }\end{array}$ & $\begin{array}{l}\text { 95\% Smallest } \\
\text { municipalities }\end{array}$ & $\begin{array}{l}5 \% \text { Largest } \\
\text { municipalities }\end{array}$ \\
\hline & \multicolumn{6}{|c|}{ Panel A: Baseline } \\
\hline \multirow[t]{3}{*}{$\Delta$ Share of allocated refugees in $\%$ of local population } & $-1.365 * *$ & 3.759 & -0.799 & -0.535 & $0.821 * *$ & 0.563 \\
\hline & $(0.538)$ & $(2.742)$ & $(0.489)$ & $(3.393)$ & $(0.386)$ & $(1.840)$ \\
\hline & \multicolumn{6}{|c|}{ Panel B: Immigrants } \\
\hline \multirow[t]{2}{*}{$\Delta$ Share of allocated refugees in $\%$ of local population } & $-1.355 * *$ & 2.775 & -0.799 & 0.013 & $0.822 * *$ & 0.543 \\
\hline & $(0.536)$ & $(2.255)$ & $(0.490)$ & $(3.508)$ & $(0.389)$ & $(1.946)$ \\
\hline \multirow{3}{*}{$\begin{array}{l}\Delta \text { Share of allocated refugees in } \% \text { of local population*share of } \\
\text { immigrants }\end{array}$} & $-2.148 * * *$ & $-1.509 * *$ & 0.045 & 0.840 & -0.203 & -0.032 \\
\hline & $(0.553)$ & $(0.725)$ & $(0.393)$ & $(0.661)$ & $(0.319)$ & $(0.479)$ \\
\hline & \multicolumn{6}{|c|}{ Panel C: Log gross income pc } \\
\hline \multirow[t]{2}{*}{$\Delta$ Share of allocated refugees in $\%$ of local population } & $-1.284 * *$ & 4.354 & -0.779 & -0.405 & $0.800 * *$ & 0.219 \\
\hline & $(0.524)$ & $(2.931)$ & $(0.490)$ & $(3.644)$ & $(0.383)$ & $(1.792)$ \\
\hline \multirow{3}{*}{$\begin{array}{l}\Delta \text { Share of allocated refugees in } \% \text { of local population*log gross } \\
\text { income pc }\end{array}$} & $-1.794 * * *$ & 1.913 & -0.446 & 0.417 & 0.472 & $-1.107 *$ \\
\hline & $(0.627)$ & $(1.631)$ & $(0.401)$ & $(1.421)$ & $(0.419)$ & $(0.659)$ \\
\hline & \multicolumn{6}{|c|}{ Panel D: Share of rich } \\
\hline \multirow[t]{2}{*}{$\Delta$ Share of allocated refugees in $\%$ of local population } & $-1.456 * * *$ & $5.099 *$ & $-0.880^{*}$ & -0.569 & $0.872 * *$ & 0.079 \\
\hline & $(0.544)$ & $(3.035)$ & $(0.499)$ & $(3.853)$ & $(0.387)$ & $(1.858)$ \\
\hline \multirow{3}{*}{$\begin{array}{l}\Delta \text { Share of allocated refugees in } \% \text { of local population*share of } \\
\text { rich in in } \% \text { of population }\end{array}$} & $-0.799 * *$ & 2.997 & $-0.707 *$ & -0.076 & 0.447 & -1.084 \\
\hline & $(0.387)$ & $(1.924)$ & $(0.389)$ & $(1.606)$ & $(0.324)$ & $(0.660)$ \\
\hline & \multicolumn{6}{|c|}{ Panel E: Crime rate } \\
\hline \multirow[t]{2}{*}{$\Delta$ Share of allocated refugees in $\%$ of local population } & $-1.232 * *$ & $4.155^{*}$ & -0.768 & -0.726 & $0.795 * *$ & 0.522 \\
\hline & $(0.523)$ & $(2.479)$ & $(0.475)$ & $(3.152)$ & $(0.375)$ & $(1.825)$ \\
\hline \multirow{3}{*}{$\begin{array}{l}\Delta \text { Share of allocated refugees in } \% \text { of local population*reported } \\
\text { crime rate }\end{array}$} & $-2.079 * * *$ & $-0.893^{*}$ & -0.486 & 0.429 & 0.415 & 0.094 \\
\hline & $(0.616)$ & $(0.538)$ & $(0.421)$ & $(0.461)$ & $(0.279)$ & $(0.338)$ \\
\hline & \multicolumn{6}{|c|}{ Panel F: Share of church tax payers } \\
\hline \multirow[t]{2}{*}{$\Delta$ Share of allocated refugees in $\%$ of local population } & $-1.391 * * *$ & 3.241 & -0.786 & -0.302 & $0.816^{* *}$ & 0.558 \\
\hline & $(0.517)$ & $(2.254)$ & $(0.483)$ & $(3.392)$ & $(0.388)$ & $(1.906)$ \\
\hline \multirow{3}{*}{$\begin{array}{l}\Delta \text { Share of allocated refugees in } \% \text { of local population*share of } \\
\text { church tax payers }\end{array}$} & $1.769 * * *$ & $1.733^{* *}$ & $-0.897 * *$ & -0.780 & 0.342 & 0.017 \\
\hline & $(0.573)$ & $(0.730)$ & $(0.397)$ & $(0.765)$ & $(0.379)$ & $(0.510)$ \\
\hline & \multicolumn{6}{|c|}{ Panel G: Unemployment } \\
\hline$\Delta$ Share of allocated refugees in $\%$ of local population & $-1.302 * *$ & $7.698 * *$ & $-0.916^{*}$ & -1.075 & $0.897 * *$ & -0.260 \\
\hline & $(0.537)$ & $(3.342)$ & $(0.503)$ & $(4.386)$ & $(0.385)$ & $(2.157)$ \\
\hline$\Delta$ Share of allocated refugees in $\%$ of local population*local & -0.429 & $-3.657 * * *$ & $0.795 * *$ & 0.501 & -0.518 & 0.764 \\
\hline unemployment rate & $(0.451)$ & $(1.144)$ & $(0.345)$ & $(1.416)$ & $(0.443)$ & $(1.006)$ \\
\hline & & Panel & H: Share of welf & e dependent imn & igrants & \\
\hline$\Delta$ Share of allocated refugees in $\%$ of local population & $-1.313 * *$ & 6.815 & $-0.833^{*}$ & -1.831 & $0.841 * *$ & -0.662 \\
\hline & $(0.529)$ & $(4.475)$ & $(0.495)$ & $(3.113)$ & $(0.386)$ & $(2.562)$ \\
\hline$\Delta$ Share of allocated refugees in $\%$ of local population*share of & $-0.862 * *$ & -2.509 & 0.567 & 1.064 & -0.328 & 1.006 \\
\hline welfare dependent among immigrants & $(0.422)$ & $(3.096)$ & $(0.348)$ & $(2.603)$ & $(0.310)$ & $(1.848)$ \\
\hline & & Panel I: S & are younger that & 65 with a tertiary & education & \\
\hline$\Delta$ Share of allocated refugees in $\%$ of local population & $-1.374 * *$ & 3.407 & $-0.806^{*}$ & -0.863 & $0.817 * *$ & 1.015 \\
\hline & $(0.537)$ & $(2.575)$ & $(0.484)$ & $(2.482)$ & $(0.384)$ & $(1.491)$ \\
\hline$\Delta$ Share of allocated refugees in $\%$ of local population*Share & 0.089 & 0.548 & 0.069 & 0.510 & 0.045 & -0.703 \\
\hline younger than 65 with a tertiary education & $(0.402)$ & $(1.333)$ & $(0.307)$ & $(1.787)$ & $(0.365)$ & $(0.817)$ \\
\hline Time FE & & & & & & \\
\hline $\mathrm{N}$ & & & & & & \\
\hline Municipalities & & & & & & \\
\hline
\end{tabular}


Table A12b. Response to Refugee Allocation, Municipal Characteristics, Municipal Elections

\begin{tabular}{|c|c|c|c|c|c|c|}
\hline \multirow{3}{*}{ Dependent variable: } & (1) & (2) & (3) & (4) & (5) & (6) \\
\hline & \multicolumn{6}{|c|}{$\begin{array}{l}\Delta \text { Share of votes for } \\
\text { other (centre small) }\end{array}$} \\
\hline & $\begin{array}{l}\text { 95\% Smallest } \\
\text { municipalities }\end{array}$ & $\begin{array}{c}\text { 5\% Largest } \\
\text { municipalities }\end{array}$ & $\begin{array}{l}\text { 95\% Smallest } \\
\text { municipalities }\end{array}$ & $\begin{array}{c}\text { 5\% Largest } \\
\text { municipalities }\end{array}$ & $\begin{array}{l}\text { 95\% Smallest } \\
\text { municipalities }\end{array}$ & $\begin{array}{c}\text { 5\% Largest } \\
\text { municipalities }\end{array}$ \\
\hline & \multicolumn{6}{|c|}{ Panel A: Baseline } \\
\hline \multirow[t]{3}{*}{$\Delta$ Share of allocated refugees in $\%$ of local population } & $-3.327 * *$ & $11.613 * *$ & -0.421 & $-4.518^{*}$ & 1.433 & -5.359 \\
\hline & $(1.486)$ & $(5.024)$ & $(1.574)$ & $(2.434)$ & $(1.446)$ & $(3.799)$ \\
\hline & \multicolumn{6}{|c|}{ Panel B: Immigrants } \\
\hline \multirow[t]{2}{*}{$\Delta$ Share of allocated refugees in $\%$ of local population } & $-3.189 * *$ & $11.133 * *$ & -0.418 & $-4.683^{*}$ & 1.642 & -5.792 \\
\hline & $(1.500)$ & $(5.029)$ & $(1.602)$ & $(2.457)$ & $(1.420)$ & $(3.899)$ \\
\hline \multirow{3}{*}{$\begin{array}{l}\Delta \text { Share of allocated refugees in } \% \text { of local population*share of } \\
\text { immigrants }\end{array}$} & -1.034 & -1.003 & -0.021 & -0.344 & $-1.573^{*}$ & -0.903 \\
\hline & $(1.093)$ & $(2.103)$ & $(1.023)$ & $(1.004)$ & $(0.864)$ & $(1.787)$ \\
\hline & \multicolumn{6}{|c|}{ Panel C: Log gross income pc } \\
\hline \multirow[t]{2}{*}{$\Delta$ Share of allocated refugees in $\%$ of local population } & $-3.144 * *$ & $12.409 * *$ & -0.508 & $-5.426^{* *}$ & 1.484 & -4.674 \\
\hline & $(1.488)$ & $(5.065)$ & $(1.600)$ & $(2.176)$ & (1.453) & (4.143) \\
\hline \multirow{3}{*}{$\begin{array}{l}\Delta \text { Share of allocated refugees in } \% \text { of local population*log gross } \\
\text { income pc }\end{array}$} & -1.651 & 3.325 & 0.786 & $-3.794 * *$ & -0.463 & 2.866 \\
\hline & $(1.129)$ & $(2.474)$ & $(1.317)$ & $(1.509)$ & $(1.254)$ & $(1.982)$ \\
\hline & \multicolumn{6}{|c|}{ Panel D: Share of rich } \\
\hline \multirow[t]{2}{*}{$\Delta$ Share of allocated refugees in $\%$ of local population } & $-3.366 * *$ & $12.995 * *$ & -0.398 & $-6.000 * *$ & 1.445 & -3.797 \\
\hline & $(1.477)$ & $(5.555)$ & $(1.562)$ & $(2.387)$ & $(1.452)$ & $(4.436)$ \\
\hline \multirow{3}{*}{$\begin{array}{l}\Delta \text { Share of allocated refugees in } \% \text { of local population*share of } \\
\text { rich in in } \% \text { of population }\end{array}$} & -0.758 & 3.321 & 0.459 & $-3.562 * *$ & 0.242 & 3.754 \\
\hline & $(1.021)$ & $(3.075)$ & $(1.284)$ & $(1.744)$ & $(1.269)$ & $(2.540)$ \\
\hline & \multicolumn{6}{|c|}{ Panel E: Crime rate } \\
\hline \multirow[t]{2}{*}{$\Delta$ Share of allocated refugees in $\%$ of local population } & $-3.246^{* *}$ & $12.564 * *$ & -0.436 & $-4.700^{*}$ & 1.452 & -5.248 \\
\hline & $(1.473)$ & $(5.007)$ & $(1.579)$ & $(2.417)$ & $(1.455)$ & $(3.866)$ \\
\hline \multirow{3}{*}{$\begin{array}{l}\Delta \text { Share of allocated refugees in } \% \text { of local population*reported } \\
\text { crime rate }\end{array}$} & $-1.954^{*}$ & -1.716 & 0.359 & 0.328 & -0.457 & -0.201 \\
\hline & $(1.131)$ & $(1.541)$ & $(0.953)$ & $(0.734)$ & $(0.830)$ & $(1.237)$ \\
\hline & \multicolumn{6}{|c|}{ Panel F: Share of church tax payers } \\
\hline \multirow[t]{2}{*}{$\Delta$ Share of allocated refugees in $\%$ of local population } & $-3.327 * *$ & $11.364 * *$ & -0.421 & $-4.477 *$ & 1.432 & -5.563 \\
\hline & $(1.481)$ & $(5.038)$ & $(1.577)$ & $(2.438)$ & $(1.470)$ & $(3.781)$ \\
\hline \multirow{3}{*}{$\begin{array}{l}\Delta \text { Share of allocated refugees in } \% \text { of local population*share of } \\
\text { church tax payers }\end{array}$} & 0.696 & 1.376 & -0.739 & -0.226 & 1.535 & 1.126 \\
\hline & $(1.256)$ & $(2.476)$ & $(1.700)$ & $(1.158)$ & $(1.313)$ & $(2.017)$ \\
\hline & \multicolumn{6}{|c|}{ Panel G: Unemployment } \\
\hline$\Delta$ Share of allocated refugees in $\%$ of local population & $-3.188 * *$ & $18.800 * * *$ & -0.448 & $-7.655^{* * *}$ & 1.267 & -7.230 \\
\hline & $(1.450)$ & $(6.150)$ & $(1.526)$ & $(2.669)$ & $(1.440)$ & $(5.565)$ \\
\hline$\Delta$ Share of allocated refugees in $\%$ of local population*local & -0.903 & $-7.139 * *$ & 0.172 & $3.116^{* *}$ & 1.081 & 1.859 \\
\hline unemployment rate & $(1.258)$ & $(3.460)$ & $(1.350)$ & $(1.466)$ & $(1.149)$ & $(3.845)$ \\
\hline & & Pane & H: Share of welfa & e dependent imr & igrants & \\
\hline$\Delta$ Share of allocated refugees in $\%$ of local population & $-3.231 * *$ & $21.176^{*}$ & -0.440 & -7.800 & 1.503 & -6.183 \\
\hline & $(1.470)$ & $(10.989)$ & $(1.560)$ & $(5.135)$ & $(1.423)$ & $(8.271)$ \\
\hline$\Delta$ Share of allocated refugees in $\%$ of local population*share of & -0.943 & -7.718 & 0.182 & 2.649 & -0.690 & 0.665 \\
\hline welfare dependent among immigrants & $(1.150)$ & $(7.489)$ & $(1.085)$ & $(3.357)$ & $(1.137)$ & $(6.381)$ \\
\hline & & Panel I: & are younger than & 65 with a tertiar & education & \\
\hline$\Delta$ Share of allocated refugees in $\%$ of local population & $-3.438 * *$ & $11.716^{* *}$ & -0.567 & -3.702 & 1.627 & -6.497 \\
\hline & $(1.499)$ & $(4.859)$ & $(1.618)$ & $(2.600)$ & $(1.458)$ & $(4.055)$ \\
\hline$\Delta$ Share of allocated refugees in $\%$ of local population*Share & 0.845 & -0.146 & 1.106 & -1.162 & -1.474 & 1.620 \\
\hline younger than 65 with a tertiary education & $(0.998)$ & $(2.979)$ & $(1.308)$ & $(1.240)$ & $(0.981)$ & $(2.342)$ \\
\hline Time FE & & & & & & \\
\hline $\mathrm{N}$ & & & & & & \\
\hline Municipalities & & & & & & \\
\hline
\end{tabular}

Note: Danish Municipal elections 1989-1997. Share of allocated refugees are in percent of the local population size in 1986. Estimates are weighted by municipal population size in 1986. Mean of the election cycle change in share of allocated refugees is: $0.13 \%$. All predictors are standardized with mean 0 and standard deviation 1. Heteroscedasticity robust standard errors in parentheses. $* * * \mathrm{p}<0.01, * * \mathrm{p}<0.05, * \mathrm{p}<0.1$. 
Table A13. Decomposition, Change in Vote Shares for Anti-immigration Parties and Municipal Characteristics

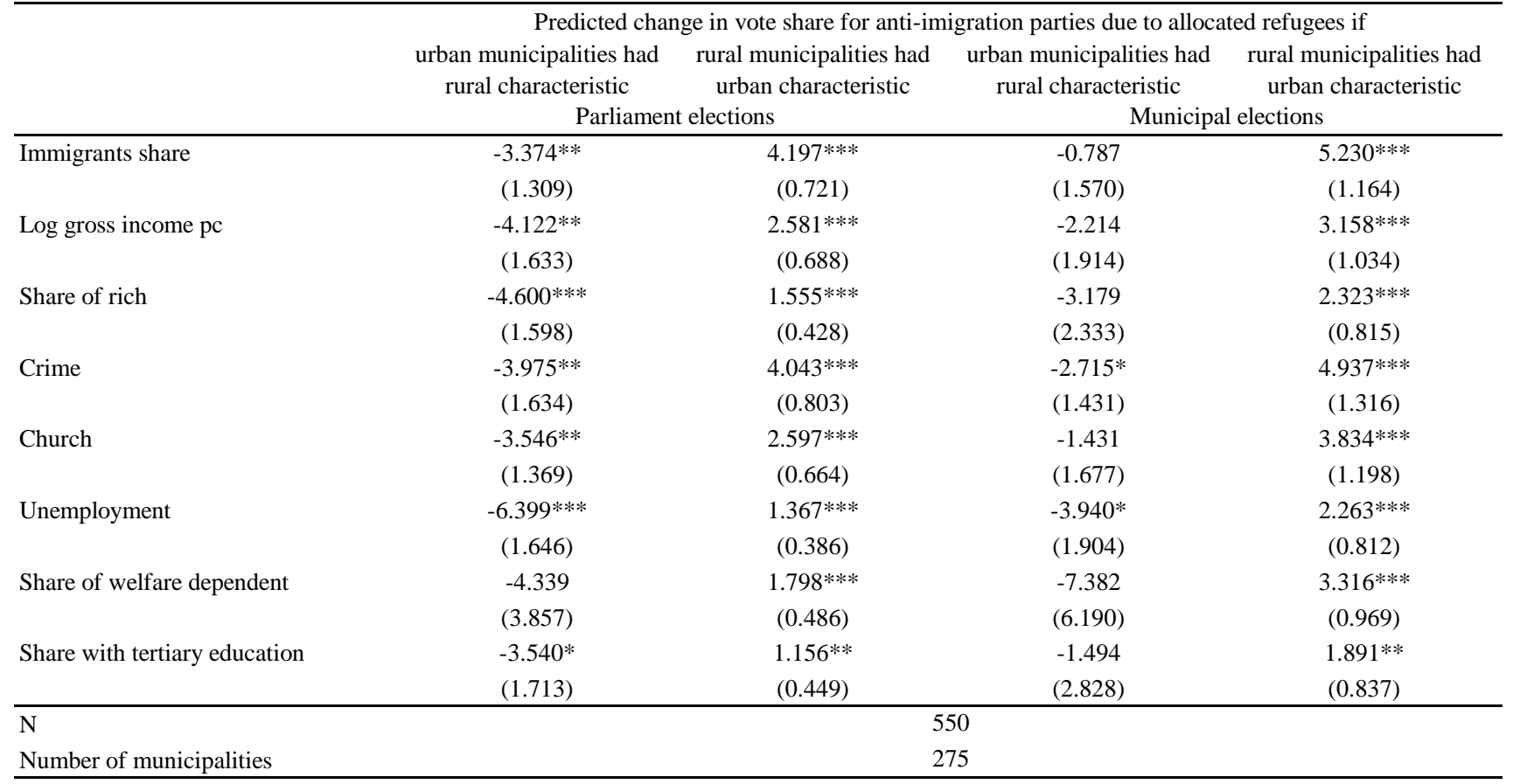

Note: Danish Parliament elections 1990-1998 and Danish municipal elections 1989-1997. Refugee share in percent of local population in 1986. Heteroscedasticity robust standard errors in parentheses. ${ }^{* * *} \mathrm{p}<0.01,{ }^{* *} \mathrm{p}<0.05$, * $\mathrm{p}<0.1$ 
Table A14. Anti-immigration Parties Standing in Municipal Elections

\begin{tabular}{lcc} 
& $\begin{array}{c}\text { No. (\%) of municipalities "Danish } \\
\text { People's Party" is not running in }\end{array}$ & $\begin{array}{c}\text { No. (\%) of municipalities "Danish } \\
\text { People's Party" is running in }\end{array}$ \\
\hline $\begin{array}{l}\text { No. (\%) of municipalities the "Progress } \\
\text { Party" is not running in }\end{array}$ & 75 & $\begin{array}{l}\text { Panel A: Municipal elections 1993 } \\
(27.3 \%)\end{array}$ \\
No. (\%) of municipalities the "Progress & 200 & 0 \\
Party" is running in & $(72.7 \%)$ & $(0 \%)$ \\
\hline & Panel B: Municipal elections 1997 \\
\hline No. (\%) of municipalities the "Progress & 53 & $(9.5 \%)$ \\
Party" is not running in & $(19.3 \%)$ & 116 \\
No. (\%) of municipalities the "Progress & 80 & $(42.2 \%)$ \\
Party" is running in & $(29.1 \%)$ &
\end{tabular}

Note: Danish municipal elections 1993 and 1997. Voting statistics from the Statistics Denmark Database for municipal elections. 


\begin{tabular}{|c|c|c|c|c|}
\hline Survey Name & \multicolumn{3}{|c|}{ Danish National Election Survey } & European Social Survey \\
\hline Data Reference & Election Study (1990) & Election Study (1994) & Election Study (1998) & $\begin{array}{l}\text { ESS Round 1: European Social Survey Round 1 Data (2002). Data file edition 6.5. NSD - } \\
\text { Norwegian Centre for Research Data, Norway - Data Archive and distributor of ESS data for ESS } \\
\text { ERIC }\end{array}$ \\
\hline Available & \multicolumn{3}{|c|}{ For all Danish Parliament elections from 1971-2015 } & Biannually from 2002-2014 \\
\hline Survey years used in this article & 1990 & 1994 & 1998 & 2002 (Results from Denmark only are used) \\
\hline Collection Method & \multicolumn{3}{|c|}{ Face-to-face interviews } & Face-to-face interviews \\
\hline Purpose & \multicolumn{3}{|c|}{$\begin{array}{l}\text { The purpose of the studies is to contribute to research about elections and voting behaviour. The } \\
\text { individual studies concern one specific general election and the political issues, which were } \\
\text { important during this election. }\end{array}$} & $\begin{array}{l}\text { To monitor and interpret changing public attitudes and values within Europe and to investigate how } \\
\text { they interact with Europe's changing institutions, and to advance and consolidate improved methods } \\
\text { of cross-national survey measurement in Europe and beyond. }\end{array}$ \\
\hline Fieldwork period & \multicolumn{3}{|c|}{ Immediately after any Parliament election since 1971} & 1-4 months between September and December \\
\hline Population & \multicolumn{3}{|c|}{ Danish citizens aged 18 and above } & All individuals aged 15 and over in Denmark \\
\hline Sample size & 1008 & 2021 & 2001 & 1506 \\
\hline For further information see & \multicolumn{3}{|c|}{ http://www.valgprojektet.dk/ } & http://www.europeansocialsurvey.org/ \\
\hline
\end{tabular}




\begin{tabular}{|c|c|c|c|}
\hline & Mean & Std. Dev & $\mathrm{N}$ \\
\hline \multicolumn{4}{|c|}{ Panel A: Questions on attitudes towards refugees and immigrants } \\
\hline $\begin{array}{l}\text { I shall read some public tasks to you, and I ask you for each of these tasks } \\
\text { to say whether you think the public uses too much money, a suitable } \\
\text { amount, or too little money on these task: Aid to refugees }\end{array}$ & 0.320 & 0.316 & 4362 \\
\hline $\begin{array}{l}\text { The parties disagree on how many refugees we can receive. Some think we } \\
\text { receive far too many. Others say we can easily take more refugees. Here is } \\
\text { a scale. Where about would you place: Yourself }\end{array}$ & 0.550 & 0.401 & 3597 \\
\hline $\begin{array}{l}\text { Refugees and immigrants should have the same right as Danes to social } \\
\text { security, even though they may not be Danish citizens }\end{array}$ & 0.354 & 0.357 & 3536 \\
\hline Immigrants constitute a threat to our national culture & 0.358 & 0.269 & 3560 \\
\hline Voted for an anti-immigration party at last election & 0.055 & 0.228 & 4625 \\
\hline \multicolumn{4}{|l|}{ Panel B: Individual characteristics } \\
\hline Male & 0.494 & 0.500 & 4625 \\
\hline Female & 0.506 & 0.500 & 4625 \\
\hline Age: $<30$ & 0.244 & 0.430 & 4625 \\
\hline Age: 30 - 44 & 0.310 & 0.463 & 4625 \\
\hline Age: 45 - 59 & 0.190 & 0.392 & 4625 \\
\hline Age: $59<$ & 0.256 & 0.436 & 4625 \\
\hline No education & 0.289 & 0.453 & 4625 \\
\hline Professional education: Basic & 0.085 & 0.278 & 4625 \\
\hline Advanced with a degree & 0.348 & 0.477 & 4625 \\
\hline Advanced short & 0.081 & 0.274 & 4625 \\
\hline Advanced medium & 0.118 & 0.323 & 4625 \\
\hline Advanced long & 0.079 & 0.269 & 4625 \\
\hline
\end{tabular}

Note: Data is from the Danish Election Survey 1990-1998, 1008 observations in 1990, 2001 observations in 1994 and 2021 observations in 1998. All attitude questions are normalized to range between 0 and 1 from an original scale of 1-5 (1-3 in the question regarding money spend on refugee aid) where the highest value is most in favor of refugees and immigrants. Estimates are weighted with full municipal population size divided by survey municipal population size. Individuals failing to answer the respective question or with missing controls are excluded. 
Table A16. Descriptive Statistics, ESS Data

\begin{tabular}{|c|c|c|c|}
\hline & Mean & Std. Dev & $\bar{N}$ \\
\hline $\begin{array}{l}\text { The government shoud be generous in judging people's applications for } \\
\text { refugee status }\end{array}$ & 0.444 & 0.261 & 1403 \\
\hline $\begin{array}{l}\text { While their cases are being considered, the Danish government should give } \\
\text { financial support to applicants }\end{array}$ & 0.681 & 0.198 & 1426 \\
\hline $\begin{array}{l}\text { While their applications for refugee status are being considered, people should } \\
\text { be allowed to work in Denmark }\end{array}$ & 0.663 & 0.253 & 1425 \\
\hline $\begin{array}{l}\text { Refugees whose applications are granted should be entitled to bring in their } \\
\text { close family members }\end{array}$ & 0.487 & 0.287 & 1420 \\
\hline Denmark has more than its fair share of people applying for refugee status & 0.452 & 0.266 & 1305 \\
\hline $\begin{array}{l}\text { Most applicants for refugee status aren't in real fear of persecution in their } \\
\text { own country }\end{array}$ & 0.472 & 0.267 & 1263 \\
\hline $\begin{array}{l}\text { While their cases are being considered, applicants should be kept in detention } \\
\text { centres }\end{array}$ & 0.450 & 0.272 & 1403 \\
\hline $\begin{array}{l}\text { Most people who come to live here work and pay taxes. They also use health } \\
\text { and welfare services. On balance, do you think people who come here take out } \\
\text { more than they put in or put in more than they take out? }\end{array}$ & 0.413 & 0.212 & 1370 \\
\hline $\begin{array}{l}\text { Average wages and salaries are generally brought down by people coming to } \\
\text { live and work here }\end{array}$ & 0.617 & 0.241 & 1342 \\
\hline $\begin{array}{l}\text { Would you say that people who come to live here generally take jobs away } \\
\text { from workers in Denmark, or generally help to create new jobs? }\end{array}$ & 0.561 & 0.179 & 1383 \\
\hline $\begin{array}{l}\text { Do you have any friends who have come to live in Denmark from another } \\
\text { country? }\end{array}$ & 0.475 & 0.500 & 1464 \\
\hline $\begin{array}{l}\text { Do you have any colleagues at work who have come to live in Denmark from } \\
\text { another country? }\end{array}$ & 0.514 & 0.500 & 1138 \\
\hline \multicolumn{4}{|l|}{ Individual characteristics: } \\
\hline Male & 0.509 & 0.500 & 1473 \\
\hline Female & 0.491 & 0.500 & 1473 \\
\hline Age $<30$ & 0.196 & 0.397 & 1473 \\
\hline Age $30-44$ & 0.282 & 0.450 & 1473 \\
\hline Age $45-59$ & 0.280 & 0.449 & 1473 \\
\hline Age $>59$ & 0.242 & 0.428 & 1473 \\
\hline Low education (ISCED 0-2) & 0.246 & 0.431 & 1473 \\
\hline Mid-level education (ISCED 3-4) & 0.466 & 0.499 & 1473 \\
\hline High education (ISCED 5-6) & 0.289 & 0.453 & 1473 \\
\hline
\end{tabular}

Note: Data from the European Social Survey round 1 (2002). See "ESS Round 1: European Social Survey (2016):

ESS-1 2002 Documentation Report. Edition 6.5. Bergen, European Social Survey Data Archive, NSD - Norwegian Centre for Research Data for ESS ERIC" for full documentation of variables. Post stratification weights are applied. The questions in rows 1-11 are originally on a 5 or 10 level scale. Here we have recoded them to be in the range 0-1 with 1 being the category most in favor of refugees and immigrants. Immigrant friends (colleagues) (row 12-13): 1 if the respondent has some immigrant friends (colleagues). 
Table A17: Determinants of Attitudes towards Refugees in Denmark (2002/2003)

\begin{tabular}{|c|c|c|c|c|c|c|c|c|c|c|c|c|c|c|}
\hline \multirow{2}{*}{$\begin{array}{l}\text { Dependent variable: } \\
\text { Big city }\end{array}$} & \multicolumn{2}{|c|}{ Generous applications } & \multicolumn{2}{|c|}{ Financial support } & \multicolumn{2}{|c|}{ Allow to work } & \multicolumn{2}{|c|}{ Bring family } & \multicolumn{2}{|c|}{ Fair share } & \multicolumn{2}{|c|}{ Fear of persecution } & \multicolumn{2}{|c|}{ Kept in centres } \\
\hline & $\begin{array}{c}0.0402 * * * \\
(0.0153)\end{array}$ & $\begin{array}{l}0.0320^{\text {*** }} \\
(0.0155)\end{array}$ & $\begin{array}{r}0.0243^{* *} \\
(0.0114)\end{array}$ & $\begin{array}{r}0.0238^{* *} \\
(0.0116)\end{array}$ & $\begin{array}{c}0.0428 * * * * \\
(0.0146)\end{array}$ & $\begin{array}{c}0.0394 * * * * \\
(0.0148)\end{array}$ & $\begin{array}{l}0.0418^{* *} \\
(0.0167)\end{array}$ & $\begin{array}{c}0.0249 \\
(0.0166)\end{array}$ & $\begin{array}{c}0.0449^{* * * *} \\
(0.0166)\end{array}$ & $\begin{array}{l}0.0311^{*} \\
(0.0167)\end{array}$ & $\begin{array}{c}0.0551^{* * * *} \\
(0.0165)\end{array}$ & $\begin{array}{l}0.0401 * * \\
(0.0162)\end{array}$ & $\begin{array}{l}0.0356^{* * *} \\
(0.0161)\end{array}$ & $\begin{array}{c}0.0250 \\
(0.0162)\end{array}$ \\
\hline Mean of dependent variable & \multicolumn{2}{|c|}{$\begin{array}{l}0.314 \\
(0.464)\end{array}$} & \multicolumn{2}{|c|}{$\begin{array}{l}0.785 \\
(0.411)\end{array}$} & \multicolumn{2}{|c|}{$\begin{array}{l}0.748 \\
(0.434)\end{array}$} & \multicolumn{2}{|c|}{$\begin{array}{l}0.452 \\
(0.498)\end{array}$} & \multicolumn{2}{|c|}{$\begin{array}{r}0.350 \\
(0.477)\end{array}$} & \multicolumn{2}{|c|}{$\begin{array}{l}0.355 \\
(0.479)\end{array}$} & \multicolumn{2}{|c|}{$\begin{array}{c}0.368 \\
(0.482)\end{array}$} \\
\hline Controls & No & Yes & No & Yes & No & Yes & No & Yes & No & Yes & No & Yes & No & Yes \\
\hline $\mathrm{N}$ & 1403 & 1403 & 1426 & 1426 & 1425 & 1425 & 1420 & 1420 & 1305 & 1305 & 1263 & 1263 & 1403 & 1403 \\
\hline
\end{tabular}

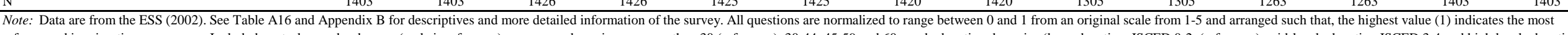
ISCED 5-6) Post stratifiction weights are applied. Individuals failing to answer the respective question or with missing controls are excluded Heteroscedasticity robust standard errors in parentheses. *** $p<0.01$, ** $\mathrm{p}<0.05$, * $\mathrm{p}<0.1$. 
Table A18: Determinants of Attitudes towards Immigration in Denmark (2002/2003)

\begin{tabular}{|c|c|c|c|c|}
\hline \multirow{2}{*}{$\begin{array}{l}\text { Dependent variable: } \\
\text { Explanatory variable: Big city }\end{array}$} & \multicolumn{2}{|c|}{ Immigrant friend } & \multicolumn{2}{|c|}{ Immigrant colleague } \\
\hline & $0.1358 * * *$ & $0.1123 * * *$ & $0.1186^{* * *}$ & $0.1029 * * *$ \\
\hline & $(0.028)$ & $(0.028)$ & $(0.028)$ & $(0.027)$ \\
\hline \multirow[t]{2}{*}{ Mean of dependent variable } & \multicolumn{2}{|c|}{0.471} & \multicolumn{2}{|c|}{0.398} \\
\hline & \multicolumn{2}{|c|}{$(0.499)$} & \multicolumn{2}{|c|}{$(0.490)$} \\
\hline Controls & No & Yes & No & Yes \\
\hline $\mathrm{N}$ & \multicolumn{2}{|c|}{1,464} & \multicolumn{2}{|c|}{1,462} \\
\hline Explanatory variable: & \multicolumn{2}{|c|}{ Immigrant friend } & \multicolumn{2}{|c|}{ Immigrant colleague } \\
\hline \multirow[t]{2}{*}{ Dependent variable: Generous applications } & $0.0741 * * *$ & $0.0700 * * *$ & 0.0184 & 0.0161 \\
\hline & $(0.015)$ & $(0.015)$ & $(0.015)$ & $(0.016)$ \\
\hline \multirow[t]{2}{*}{ Mean of dependent variable } & \multicolumn{2}{|c|}{0.314} & \multicolumn{2}{|c|}{0.314} \\
\hline & \multicolumn{2}{|c|}{$(0.464)$} & \multicolumn{2}{|c|}{$(0.464)$} \\
\hline$\overline{\mathrm{N}}$ & \multicolumn{2}{|c|}{1403} & \multicolumn{2}{|c|}{1,401} \\
\hline \multirow[t]{2}{*}{ Dependent variable: Financial support } & $0.0197 *$ & $0.0272 * *$ & 0.0017 & -0.0002 \\
\hline & $(0.011)$ & $(0.011)$ & $(0.011)$ & $(0.013)$ \\
\hline \multirow[t]{2}{*}{ Mean of dependent variable } & \multicolumn{2}{|c|}{0.785} & \multicolumn{2}{|c|}{0.785} \\
\hline & \multicolumn{2}{|c|}{$(0.411)$} & & \\
\hline $\bar{N}$ & & & & \\
\hline Dependent variable: Allow to work & $0.0603 * * *$ & $0.0668 * * *$ & 0.0128 & 0.0193 \\
\hline & $(0.014)$ & $(0.015)$ & $(0.014)$ & $(0.016)$ \\
\hline Mean of dependent variable & & & & \\
\hline & & & & \\
\hline $\mathrm{N}$ & & & & \\
\hline Dependent variable: Bring family & $0.0902 * * *$ & $0.0677 * * *$ & $0.0596 * * *$ & $0.0329 *$ \\
\hline & $(0.016)$ & $(0.016)$ & $(0.016)$ & $(0.017)$ \\
\hline Mean of dependent variable & & & & \\
\hline & & & & \\
\hline $\bar{N}$ & & & & \\
\hline Dependent variable: Fair share & $0.0753 * * *$ & $0.0541 * * *$ & $0.0788 * * *$ & $0.0514 * * *$ \\
\hline & $(0.016)$ & $(0.016)$ & $(0.016)$ & $(0.017)$ \\
\hline Mean of dependent variable & & & & \\
\hline & & & & \\
\hline $\mathrm{N}$ & & & & \\
\hline Dependent variable: Fear of persecution & $0.0784 * * *$ & $0.0488 * * *$ & $0.0683 * * *$ & 0.0244 \\
\hline & $(0.016)$ & $(0.016)$ & $(0.016)$ & $(0.017)$ \\
\hline Mean of dependent variable & & & & \\
\hline & & & & \\
\hline $\mathrm{N}$ & & & & \\
\hline Dependent variable: Kept in centres & $0.0874 * * *$ & $0.0739 * * *$ & $0.0491 * * *$ & 0.0267 \\
\hline & $(0.015)$ & $(0.016)$ & $(0.016)$ & $(0.016)$ \\
\hline Mean of dependent variable & & & & \\
\hline & & & & \\
\hline $\bar{N}$ & & & & \\
\hline
\end{tabular}

Note: Data are from the ESS (2002). See Table A16 and Appendix B for descriptives and more detailed information of the survey. Questions in column (1)-(3) are normalized to range between 0 and 1 from an original scale from 1-5 and arranged, such that the highest value (1) indicates the most refugee and immigration pro answer. Immigrant friend (colleague): 1 if the respondent has some immigrant friends (colleagues). Included controls: gender dummy (male is reference), age group dummies: younger than 30 (reference), 30-44, 45-59 and 60+ and education dummies (low education, ISCED 0-2 (reference), mid-level education ISCED 3-4 and high level education ISCED 5-6). Post stratification weights are applied. Individuals failing to answer the respective question or with missing controls are excluded. Heteroscedasticity robust standard errors in parentheses. $* * * \mathrm{p}<0.01, * * \mathrm{p}<0.05, * \mathrm{p}<0.1$. 